\title{
Guide to the Odonata of central Ñeembucú, Paraguay: indicator species of wetland habitats
}

\author{
Jeremy Kenneth Dickens (D)*, Daniel Schoenberger (D) and Michelle VanCompernolle (D) \\ Fundación Para La Tierra, Centro IDEAL, Pilar, Paraguay
}

\begin{abstract}
The department of Ñeembucú, in south-western Paraguay, is home to the virtually unexplored Neembucú Wetlands, the second largest wetland system in the country, representing a major gap in biodiversity knowledge. As organisms ubiquitous with wetlands, the Odonata, or dragonflies (Anisoptera) and damselflies (Zygoptera), have the potential to be effective indicators of wetland habitats in the face of increasing anthropogenic impacts in the region. We therefore comprehensively surveyed the Odonata in central Ñeembucú over a period of two years using a listing method. Here, we present an annotated checklist and identification key to the species present in central Neembucú with details on their habitat preferences, phenology and behaviour. We found 60 species but estimate a total of between 62 and 90 species. Eleven (18\%) are new records for Paraguay. Species composition is similar to the Argentine Humid Chaco, with four bioregional endemics, whilst representatives from the Andean-Patagonian subregion are present in open areas. Such partitioning of species from different bioregions into different habitats is typical of ecotonal regions. Two further species are endemic to the Paraná-Paraguay basin and three are highly localised, indicating the high conservation value of the Ñeembucú Wetlands. Eleven species have the potential to be effective indicators of the Paraguay River, large permanent wetlands, grassy temporary wetlands and wooded temporary wetlands, providing an effective tool to identify critical wetland ecosystems in the face of the growing threats from human activities. We also provide recommendations for the protection and management of wetlands in the region.
\end{abstract}

urn:1sid:zoobank.org:pub:FC5926FE-5007-446C-86B8-0E36E4D97856

Keywords: Chaco; dragonfly; damselfly; Esteros del Ñeembucú; Neembucú Wetlands

\section{Introduction}

Shortfalls in the knowledge of species taxonomy, distribution, abundance and tolerances present major setbacks to our understanding of patterns in biodiversity, hindering conservation planning and ecological and evolutionary studies (Hortal et al., 2015), particularly in understudied regions. Lying between some of the most biodiverse countries on earth, the small, landlocked country of Paraguay is one such overlooked region. Although it was home to some of the earliest expeditions to document natural history in South America, very little progress has since been made. Nevertheless, it has an exceptionally high level of biodiversity relative to its small size and shallow relief due to its position at the meeting point of five of the continent's terrestrial biomes (Olson et al., 2001) and four freshwater ecoregions (Hales \& Petry, 2015). Within this context, the department of Ñeembucú, sandwiched between the Paraná and Paraguay rivers in the south-west corner of the country, is one of the least explored regions of Paraguay (Mereles et al., 2005). The landscape is dominated by wetlands and flood-prone habitats, covering up to $90 \%$ of

*Corresponding author. Email: jerdickens@gmail.com 


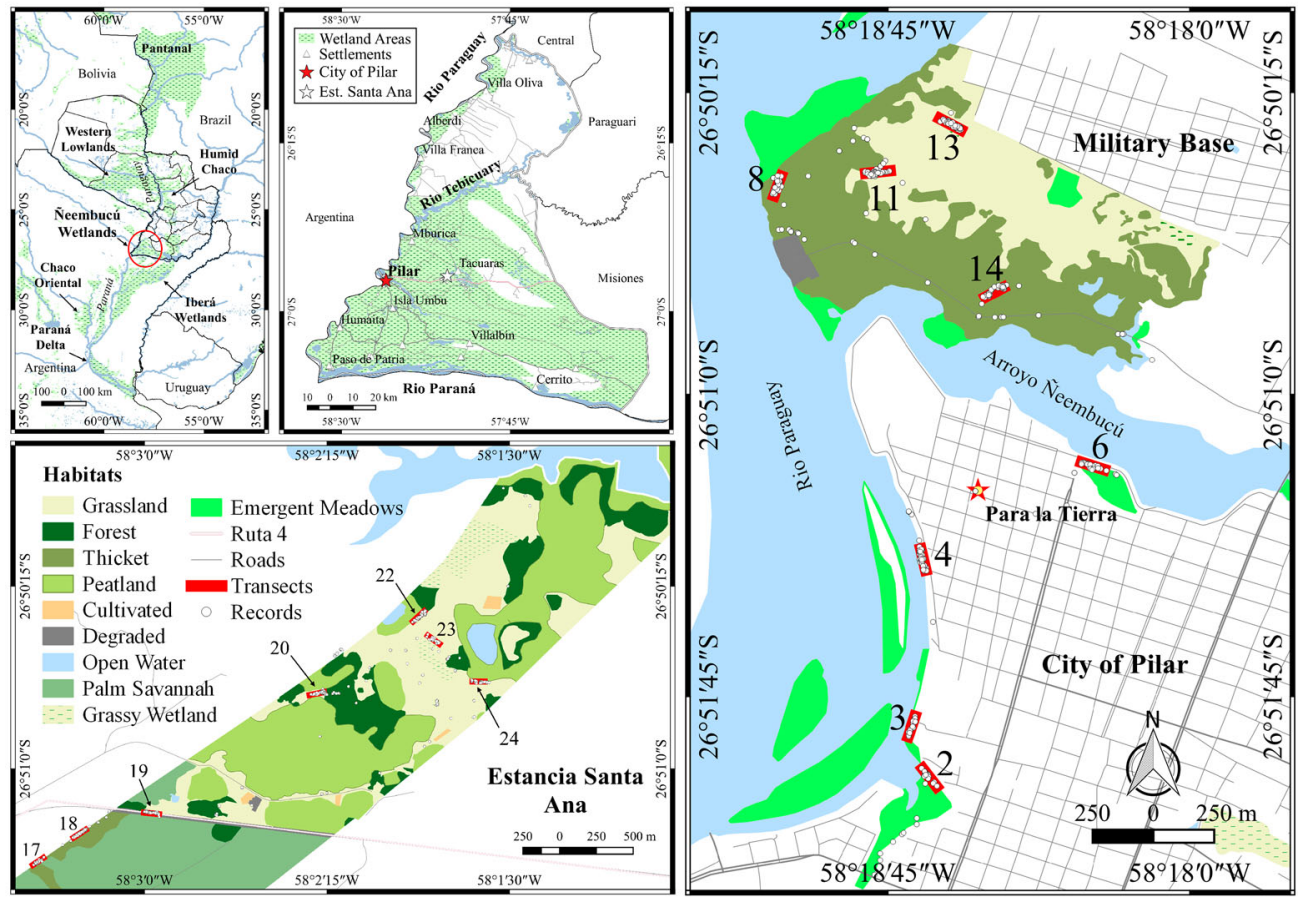

Figure 1. Map of the Neembucú department, Paraguay with localities of transects and voucher specimens collected.

the area (Contreras Roqué, Contreras Chialchia, \& Delpino Aguayo, 2007), including the second largest wetland complex in the country after the Pantanal, known as the Neembucú Wetlands or Esteros del Ñeembucú (Neiff, 2001). Much of the department is also in a near-pristine state with low human population density, making it a haven for aquatic species such as the Odonata, or dragonflies (Anisoptera) and damselflies (Zygoptera).

The Odonata are an ancient order of insects dating back to the Permian (Suhling et al., 2015). Adults are supreme aerial predators among invertebrates, flying with unrivalled speed and agility, but larvae are aquatic, a characteristic that closely ties most species to aquatic habitats. They are among the best-studied groups of insects (Suhling et al., 2015) with 5700 known species, although the actual total is estimated to be closer to 7000. The Neotropical region is the most species-rich, with over 1727 species, followed closely by the Oriental region, with 1703 species (Kalkman et al., 2008; Von Ellenrieder, 2009a). However, the Neotropics also suffer the greatest deficit in knowledge (Kalkman et al., 2008), with the rate of species discovery outstripping the rate at which new species are described (Paulson, 2004). Between 1984 and 2009, an average of just 16 new species were described annually (Paulson, 2004; Von Ellenrieder 2009a). Additionally, the vast majority of species are known from only a handful of localities, and surveys are still required for most regions, with several large areas remaining completely unsampled (Von Ellenrieder, 2009a). One of the largest of these is the Chaco biome, shared between Paraguay, Bolivia and Argentina (Paulson, 2004). Although Von Ellenrieder (2010) and Rodríguez \& Molineri (2013) recently conducted surveys in the Argentine portion, the Paraguayan and Bolivian portions remain unexplored (Kalkman et al., 2008; Von Ellenrieder, 2009a). In Paraguay, 133 Odonata species are known, almost all of which are from the eastern portion of the country, eight of which are endemic (Paulson, 2004). This is about half the number occurring in neighbouring Brazilian states and Argentina (Bedê, Machado, Piper, \& Souza, 2015), so is likely 
greatly underestimated given the lack of recent surveys and the majority of the country remaining completely unexplored, thus representing a major deficit in the knowledge of the species present.

In addition to this lack of knowledge, the natural ecosystems of the region are now facing unprecedented threats as a result of wetland drainage, changes in the flood regime caused by improper road design and construction, uncontrolled agrochemical use, deteriorating water quality, chronic overgrazing and proliferation of feral animals (Aveiro-Talavera, n.d.; Contreras Roqué et al., 2007). This is especially alarming given the important role wetlands play in ecosystem function through water provision, floodwater attenuation, water quality amelioration, groundwater recharge, increased productivity and biodiversity maintenance (Acreman \& Mountford, 2009; Maltby, 2009). At a regional scale, the Ñeembucú Wetlands also play a vital role in maintaining connectivity between a chain of wetlands running along the main channel of the Paraguay-Parana river system (Neiff, 2001), including the Pantanal Wetlands, Western Chaco Wetlands, Humid Chaco Wetlands, Ibera Wetlands, and Parana River Delta (Figure 1). In addition to their ecological importance, they underlie the socio-economic stability of the region, which relies almost entirely on aquatic resources for energy generation, trade (via shipping), food security (through fisheries and replenishment of fertile soils) and water provision (Quirós, 2003). Given their central role in maintaining ecological and socio-economic stability in the region, their conservation is critical.

In light of this, the Odonata are highly suitable for use as indicator species to monitor changes in wetland habitats by providing a measure of ecosystem health based on the species present (Clark \& Samways, 1996; Golfieri et al. 2016; Samways, 2008). This is because they are widespread and relatively diverse in wetland habitats, vary in their level of sensitivity to disturbances (including changes in water quality, substrate and vegetation structure) and are able to respond rapidly to disturbances due to their short life-cycle and high mobility as adults (Clark \& Samways, 1996; Golfieri, Hardersen, Maiolini, \& Surian, 2016; Samways, 2008). They are also conspicuous and more easily sampled and identified than most other groups of aquatic insects (Brown, 1991; Clark \& Samways, 1996; Kutcher \& Bried, 2014). Furthermore, Valente-Neto, De Oliveira Roque, Rodrigues, Juen, and Swan (2016) found that monitoring of adults alone sufficed in capturing effects on both adults and larvae. However, in order for changes in the environment to be interpreted from changes in species assemblage structure, the natural assemblages and species preferences must be known (Clark \& Samways, 1996).

Therefore, to improve the state of knowledge about the region, we undertook a comprehensive survey of the Odonata. This is the first such survey of Odonata in Paraguay and the first for the Humid Chaco outside of Argentina. As such, we present our findings in the form of a practical field guide with a comprehensive annotated checklist and key to all species recorded in central Neembucú, along with information on their distribution, habitat preferences, phenology and behaviour. We also provide suitable indicator species for the major wetland types in the region.

\section{Methods}

\section{Study site}

The department of Neembucú lies in the south-west corner of Paraguay, separated from Argentina by the Paraguay River to the west and Paraná River to the south. It is extremely flat and consists almost entirely of a large sedimentary plain known as the Yabebyry formation (Duarte, 2000), which is characterised by poorly drained soils that support hydrophilic grasslands and savannahs of the Humid Chaco, including wooded thickets and palm savannah (Dinerstein et al., 1995; Olson et al., 2001). These areas are interspersed by the loessic sediments of the Neembucú 
formation that support a mosaic of grassland and gallery forest habitats and the iconic permanent wetlands of the Neembucú Wetlands, covering an area of $4000-8000 \mathrm{~km}^{2}$. Their extent varies according to annual rainfall, which cycles between wet and dry phases, corresponding to the El Niño-Southern Oscillation (ENSO), with a 2.5-3.7 year oscillation and 8-11 year periodicity (Contreras, 2003). We carried out this study during a wet phase marked by extensive flooding. The climate is warm temperate, fully humid with hot summers (Köppen-Geiger classification Cfa; Kottek et al. 2006) and cold winters, sometimes experiencing frost. The mean annual temperature is $22.1^{\circ} \mathrm{C}$ but varies from a mean of $27.6^{\circ} \mathrm{C}$ in January to $17.6^{\circ} \mathrm{C}$ in July (climate-data.org). Mean annual rainfall is high at $1346 \mathrm{~mm}$ (climate-data.org) and peaks during April $(175 \mathrm{~mm})$ but is high even during the dry season (June to September) with August receiving the least $(46 \mathrm{~mm})$. The major aquatic habitats in the region include the Paraguay River (including the river's edge and rooted emergent meadows), large permanent wetlands or esteros (including shallow lakes and tropical peatlands), temporary grassy wetlands (including temporary pools, waterlogged short grasslands and flooded palm savannah) and temporary wooded wetlands (including temporary pools and flooded Chaco thicket) (Neiff, 2001). For the shallow lakes, extensive floating peatlands dominated by Cyperus giganteus typically border the shoreline. The departmental capital, Pilar, is situated on the left bank of the Paraguay at the confluence of the Arroyo Neembucú, which drains the Neembucú Wetlands. All field sites are located in central Neembucú, in the region adjacent the national highway (Ruta 4), as northern and southern areas of the department were inaccessible during much of the study period due to flooding. Sampling sites included the city of Pilar, the Regimiento de Caballeria $\mathrm{N}^{\circ} 2$ Coronel Felipe Toledo (henceforth referred to as the 'Military Base'), which is a patch of natural habitat in Pilar and Estancia Santa Ana in the municipality of Guazu Cuá, well within the Neembucú Wetlands (see Figure 1). We used Quantum GIS 3.4.8 (QGIS Development Team, 2019) to create site maps.

\section{Sampling design}

We set up fifteen $100 \times 10 \mathrm{~m}$ transects in or adjacent to all major habitats (see Table 1). We sampled each transect at least once per season between 26 April 2017 and 15 March 2019 during active flight periods (10:00-16:00, $>20^{\circ} \mathrm{C}$ and low wind speed). On each occasion we recorded the transect number, date, start and end times along with any changes in habitat noted since the

Table 1. Characteristics of transects used to survey Odonata species in the department of Neembucú.

\begin{tabular}{lcccc}
\hline Transect & Site & Wetland Type & Aquatic Habitat & Terrestrial Habitat \\
\hline 2 & Pilar & Large River & Emergent meadow & Urban \\
3 & Pilar & Large River & River channel & Urban \\
4 & Pilar & Large River & River channel & Urban \\
6 & Pilar & Large River & Emergent meadow & Urban \\
8 & Military Base & Large River & River channel & Thicket \\
11 & Military Base & Grassy Temporary & Temporary pool & Grassland \\
13 & Military Base & Grassy Temporary & Flooded short grassland & Grassland \\
14 & Military Base & Wooded Temporary & Temporary pools & Thicket \\
17 & Santa Ana & Wooded Temporary & Flooded savannah & Thicket \& palm savannah \\
18 & Santa Ana & Wooded Temporary & Flooded savannah & Thicket \& palm savannah \\
19 & Santa Ana & Grassy Temporary & Flooded short grassland & Thicket \& palm savannah \\
20 & Santa Ana & Large permanent & Peatland & Grassland \& Forest \\
22 & Santa Ana & Large permanent & Peatland, shallow lake & Grassland \& Forest \\
13 & Santa Ana & Grassy Temporary & Flooded short grassland & Grassland \\
24 & Santa Ana & Large permanent & Peatland, shallow Lake & Grassland \& Forest \\
\hline
\end{tabular}


last sampling events. At the beginning and end of each sampling event, we recorded temperature using a KASUNTEST digital thermometer. We used a 'listing method' to maximise species detection by recording all the morphospecies of Odonata that could be captured with an aerial net of $60 \mathrm{~cm}$ diameter per sampling event of up to a maximum $2 \mathrm{~h} 30 \mathrm{~min}$ search time. We terminated sampling if we could not find any further morphospecies after a period of $20 \mathrm{~min}$ but extended this by $10 \mathrm{~min}$ if we observed a new morphospecies that evaded capture. For each individual caught, we took high-quality photographs of the lateral, dorsal and anterior views prior to release, and deposited representatives of all morphospecies in the Colección de Invertebrados de Para La Tierra-Entomologia (CIPLT-E) in Pilar, for identification reference (see complete list of voucher specimens in Appendix III). We recorded the GPS coordinates and time for the point at which each individual was first sighted (the clock was paused if a chase ensued). For the 10 $\times 10 \mathrm{~m}$ quadrat centred around the point of capture, we estimated the following variables: distance to water $(\mathrm{m})$, water area $(\%)$, terrestrial vegetation cover $(\%)$, aquatic vegetation cover $(\%)$, mean terrestrial vegetation height $(\mathrm{m})$, maximum terrestrial vegetation height $(\mathrm{m})$, mean aquatic vegetation height $(\mathrm{m})$, maximum aquatic vegetation height $(\mathrm{m})$, height caught $(\mathrm{m})$ and shade $(\%)$. We also noted behaviour as flying, resting, copulating or laying eggs. To maximise the number of species recorded, we further recorded all identifiable species that had evaded capture after each sampling event. Whenever we found interesting specimens outside of the sampling design, we opportunistically collected them, recording locality, time and habitat whenever possible.

We identified all specimens to the lowest possible taxonomic level using identification keys, especially Garrison, Von Ellenrieder, and Louton (2006, 2010), Heckman (2006, 2008), Von Ellenrieder and Garrison (2007) and the literature relevant to each group. When necessary, we examined specimens under an AmScope SZMT2 stereomicroscope with AmScope MU1003 microscope camera. Wing venation terminology follows Riek and Kukalová-Peck (1984). Jeremy K Dickens made original drawings of morphological features important for species diagnosis, unless otherwise stated. For drawing adapted from other sources, we obtained permission from the copyright holder(s), as indicated in the figure legends.

\section{Data analyses}

We created a matrix of species incidence-frequencies per transect. From this, we estimated overall species richness with $95 \%$ lower and upper confidence limits determined by the bootstrap standard error method (100 repeats) and sample coverage using rarefaction-extrapolation in the iNEXT package (Hsieh, Ma, \& Chao, 2016) run in R software (R Development Core Team, 2015). Relative abundance was defined categorically as Abundant, Common, Frequent, Occasional or Rare, according to the limits determined by dividing the linear species abundance curve (i.e. log of frequencies) into five equal parts and then back-transforming these to actual frequencies. For each species, we tested for differences in occurrence frequencies by ecosystem (Ñeembucú Wetlands vs. Paraguay River), aquatic habitat, terrestrial habitat, season and behaviour (resting vs. flying) using chi-squared tests of independence. We used nonmetric multidimensional scaling (NMDS), based on Bray-Curtis dissimilarity indices between habitats calculated from species presence/absence per transect using the package vegan (Oksanen et al., 2013) to graphically depict the associations between species and habitats during spring-autumnsummer (henceforth SSA) and winter, separately, after removing uniques (species recorded only once) to reduce sampling bias.

We determined potential indicator species per wetland habitat type in SSA versus winter by calculating the association index between each species and habitat, for SSA or winter, using the $\mathrm{R}$ package indicspecies (De Cáceres \& Jansen, 2016). The association index is the product of the specificity value, the probability of a surveyed site belonging to a certain habitat when the species 
is found in it, and the fidelity value, the probability of finding the species in sites belonging to each habitat (De Cáceres \& Legendre, 2009; Dufrêne \& Legendre, 1997). We used permutational tests to test the associations between species and habitat during SSA and winter.

\section{Results}

We recorded 60 species in Neembucú and estimated the actual total number of species in the sampling area to be between 62 and 90 species (Figure 2). Sample coverage was high (0.96), indicating near complete sampling. Abundance curves followed a logarithmic distribution $\left[\mathrm{R}^{2}=0.96\right.$ (SSA), 0.97 (winter)], demonstrating a lack of bias towards species abundance. The most frequently recorded species were Erythrodiplax paraguayensis (Förster, 1905), Ischnura fluviatilis Selys, 1876 and Miathyria marcella (Selys in Sagra, 1857) (Figure 3a), with the addition of Erythemis peruviana (Rambur, 1842) and Erythrodiplax umbrata (Linnaeus, 1758) in SSA (Figure 3b). A mix of species typical of different biogeographical regions were present and partitioned by habitat. Species endemic to the Chaco (and hence the Rio Paraguay basin) include Gynacantha convergens Förster, 1908, Orthemis philipi Von Ellenrieder, 2009, Oligoclada rubribasalis Von Ellenrieder \& Garrison, 2008 and Aeolagrion philipi Tennessen, 2009. Most of these species were associated with wooded habitats, besides O. rubribasalis, which was exclusive to the river's edge. On the other hand, Erythrodiplax nigricans (Rambur, 1842), Tauriphila xiphea Ris, 1913 and Lestes spatula Fraser, 1946 are typical of the Andes-PatagoniaPampas subregion and found in more open grassland areas. Other species endemic to the Paraná-Paraguay basin include Aphylla distinguenda (Campion, 1920), which was associated with wooded thickets, including along the Paraguay River, and Edonis helena Needham, 1905, which was found exclusively in grassland. Species with localised distributions included Edonis helena, Erythemis carmelita Williamson, 1923 and Acanthagrion ascendens Calvert, 1909.

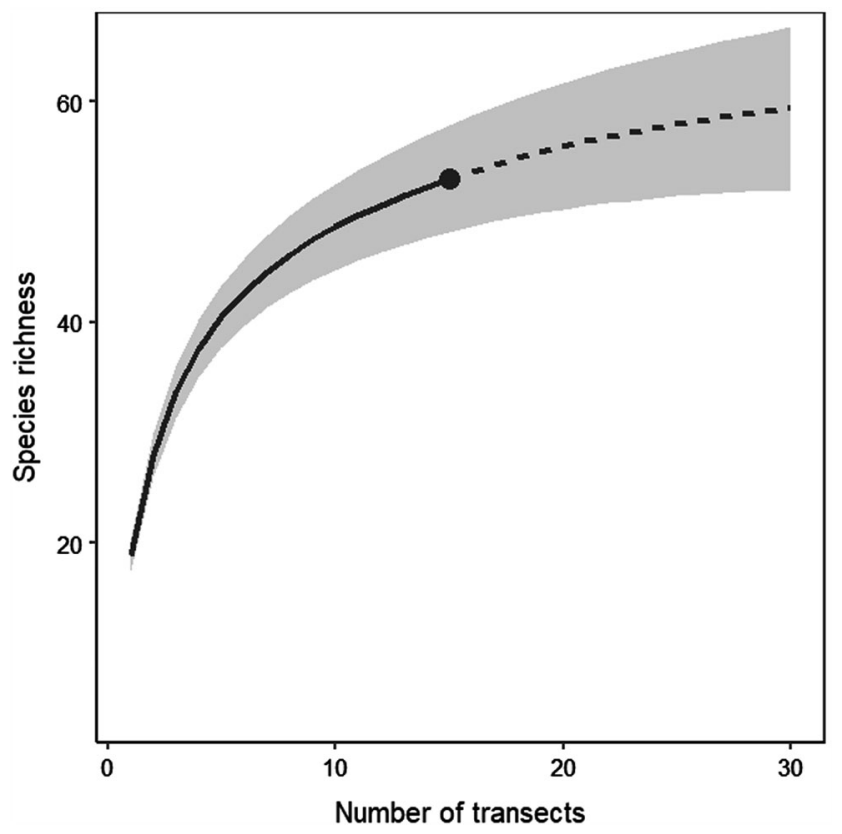

Figure 2. Species rarefaction-extrapolation curve based on species frequencies per transect. 

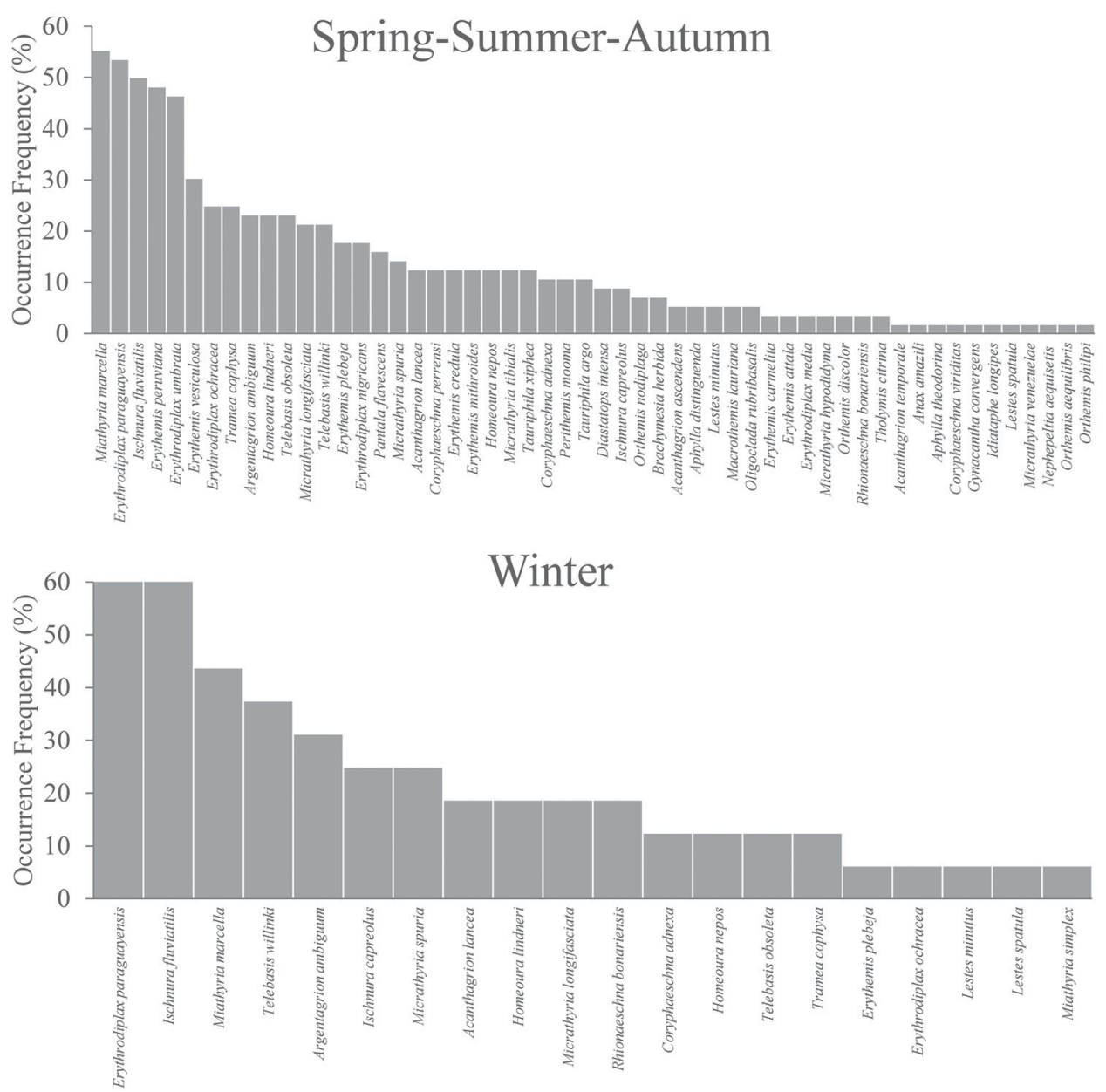

Figure 3. Species abundance curve as occurrence frequency per survey event during (a) spring-summer-autumn (SSA) and (b) winter.

During SSA, we found eight potential indicator species per wetland type (Table 2), five of which were associated with a single wetland type and three with two wetland types. Of these, the strongest associations were between Telebasis obsoleta (Selys, 1876) with large permanent and wooded temporary wetlands, Micrathyria tibialis Kirby, 1897 with wooded temporary wetlands and Micrathyria spuria (Selys, 1900) with large permanent and grassy temporary wetlands. Oligoclada rubribasalis and Perithemis mooma Kirby, 1889 are also strongly associated with the river, Acanthagrion ascendens and Micrathyria hypodidyma Calvert, 1906 to wooded temporary wetlands, and Orthemis nodiplaga Karsch, 1891 to large permanent and grassy temporary wetlands. We also recorded 14 species exclusive to a single wetland type: five to wooded temporary wetlands and three to each of the Paraguay River, large permanent wetlands, and grassy temporary wetlands (Table 3).

For winter, we found four potential indicator species (Table 2): Rhionaeschna bonariensis (Rambur, 1842) is associated with the Paraguay River, Micrathyria spuria and Tramea cophysa Hagen, 1867 with large permanent wetlands, and Telebasis willinki Fraser, 1948 with large permanent and wooded temporary wetlands. We also found six species exclusive to a single wetland 
Table 2. Potential indicator species $(p<0.1)$ per wetland type in central Neembucú based on occurrence frequency per site in spring-summer-autumn (SSA) vs. winter. The specificity value is the probability of a surveyed site belonging to a certain habitat when the species is found in it, and the fidelity value is the probability of finding the species in sites belonging to each habitat. The association index is the average between these values, as a measure of both fidelity and specificity. The $p$-value represents the results of permutational tests (999 permutations) of the association between species and wetland type.

\begin{tabular}{|c|c|c|c|c|c|}
\hline & Season & Specificity & Fidelity & $\begin{array}{l}\text { Association } \\
\text { Index }\end{array}$ & $p$ \\
\hline \multicolumn{6}{|l|}{ LARGE PERMANENT } \\
\hline Micrathyria spuria & Winter & 0.80 & 1.00 & 0.89 & 0.022 \\
\hline Tramea cophysa & Winter & 1.00 & 0.67 & 0.82 & 0.051 \\
\hline \multicolumn{6}{|l|}{ RIVER } \\
\hline Perithemis mooma & SSA & 0.80 & 0.80 & 0.80 & 0.043 \\
\hline Oligoclada rubribasalis & SSA & 1.00 & 0.60 & 0.78 & 0.031 \\
\hline Rhionaeschna bonariensis & Winter & 1.00 & 0.60 & 0.78 & 0.045 \\
\hline \multicolumn{6}{|l|}{ WOODED TEMPORARY } \\
\hline Micrathyria tibialis & SSA & 0.91 & 1.00 & 0.95 & 0.005 \\
\hline Acanthagrion ascendens & SSA & 1.00 & 0.67 & 0.82 & 0.065 \\
\hline Micrathyria hypodidyma & SSA & 1.00 & 0.67 & 0.82 & 0.048 \\
\hline \multicolumn{6}{|l|}{ LARGE PERMANENT \& } \\
\hline \multicolumn{6}{|l|}{ GRASSY TEMPORARY } \\
\hline Micrathyria spuria & SSA & 0.91 & 0.86 & 0.88 & 0.005 \\
\hline Orthemis nodiplaga & SSA & 1.00 & 0.57 & 0.76 & 0.087 \\
\hline \multicolumn{6}{|l|}{ LARGE PERMANENT \& } \\
\hline \multicolumn{6}{|l|}{ WOODED TEMPORARY } \\
\hline Telebasis obsoleta & SSA & 0.94 & 1.00 & 0.97 & 0.001 \\
\hline Telebasis willinki & Winter & 0.87 & 0.83 & 0.85 & 0.032 \\
\hline
\end{tabular}

type: two each to the large permanent wetlands and wooded temporary wetlands and one each to the Paraguay River and grassy temporary wetlands (Table 3).

The associations between species and habitats during SSA and winter are depicted in Figure 4, whilst a complete list of species associated with each wetland type, based on the indicator species analysis, is given in Table 3.

\section{Checklist to the Odonata of central Neembucú}

For the purposes of practicality of identification in the field, we provide descriptions of the most easily observed traits (i.e. colouration, size) for each species. However, colour is extremely variable and should be used with caution, so we have also included diagnostic morphological features for more accurate identification. Unless stated otherwise, we obtained information on species distributions and diagnostic traits from Garrison et al. (2006, 2010), Heckman (2006, 2008) and Von Ellenrieder \& Garrison (2007). An * indicates new records for Paraguay. Relative abundance reflects occurrence frequency, for SSA: Abundant $(>28)$, Common $(14<\mathrm{x} \leq 28)$, Frequent $(7.0<\mathrm{x} \leq 14.0)$, Occasional $(3.5<\mathrm{x} \leq 7.0)$ and Rare $(\leq 3.5)$, for winter: Abundant ( $>40)$, Common $(25<\mathrm{x} \leq 40)$, Frequent $(15<\mathrm{x} \leq 25)$, Occasional $(10<\mathrm{x} \leq 15)$ and Rare $(\leq 10)$. For each species, environmental variables measured for all recorded specimens are given in Supplemental Information Appendix I, and occurrence frequencies per ecosystem, aquatic and terrestrial habitats, season and behaviour in Supplemental Information Appendix II, Table 4. A complete list of voucher specimens is provided in Supplemental Information Appendix III. 
Lengths given for total length (TL), forewing (FW), hind wing (HW), pterostigma (PS) and abdomen $(\mathrm{AB})$ in millimetres. $\mathrm{VL}=$ vulvar lamina of female and $\mathrm{S} 1-\mathrm{S} 10$ represent abdominal segments one to ten.

Table 3. The predominant wetland habitats of central Neembucú with habitat descriptions and species with association index $\geq 0.5$ for any grouping involving each habitat. Superscripts designate potential indicator species (ind.) and exclusive species (excl.).

\begin{tabular}{|c|c|c|c|}
\hline \multirow{2}{*}{$\frac{\text { Wetland types }}{\text { Paraguay River }}$} & \multirow[b]{2}{*}{\begin{tabular}{l}
\multicolumn{1}{c}{ Description } \\
Large, permanent, flowing \\
or still water. Sand, silt \\
or muddy substrate. \\
Riparian zone with either \\
sparse macrophyte cover \\
(including trees), or \\
with emergent meadows \\
[extensive stands of \\
emergent vegetation (reeds, \\
grasses \& broad-leafed \\
plants)].
\end{tabular}} & \multicolumn{2}{|c|}{ Associated species } \\
\hline & & $\begin{array}{l}\text { Spring-summer-autumn: } \\
\text { Oligoclada } \\
\text { rubribasalis ind, excl } \\
\text { Perithemis mooma ind } \\
\text { Erythrodiplax media excl } \\
\text { Brachymesia herbida } \\
\text { Diastatops intensa } \\
\text { Erythemis attala } \\
\text { Erythrodiplax nigricans } \\
\text { Macrothemis lauriana } \\
\text { Pantala flavescens } \\
\text { Argentagrion ambiguum } \\
\text { Homeoura lindneri } \\
\text { Homeoura nepos }\end{array}$ & $\begin{array}{l}\text { Winter: } \\
\text { Rhionaeschna } \\
\text { bonariensis ind, excl } \\
\text { Miathyria marcella } \\
\text { Micrathyria longifasciata } \\
\text { Homeoura lindneri }\end{array}$ \\
\hline $\begin{array}{l}\text { Large permanent } \\
\text { wetlands }\end{array}$ & $\begin{array}{l}\text { Large, permanent, still. } \\
\text { Organic and sandy } \\
\text { substrates. Bordered by } \\
\text { extensive floating peat } \\
\text { bogs with high emergent } \\
\text { vegetation cover [i.e. } \\
\text { tall sedges (Cyperus } \\
\text { giganteus)] and regularly } \\
\text { flooded margins consisting } \\
\text { of short-grassland and } \\
\text { overhanging vegetation } \\
\text { from forest patches. }\end{array}$ & $\begin{array}{l}\text { Spring-summer-autumn: } \\
\text { Micrathyria spuria ind } \\
\text { Telebasis obsoleta }{ }^{\text {ind }} \\
\text { Orthemis nodiplaga ind } \\
\text { Aphylla theodorina excl } \\
\text { Orthemis philipi excl } \\
\text { Brachymesia herbida } \\
\text { Erythemis credula } \\
\text { Erythemis plebeja } \\
\text { Erythemis mithroides } \\
\text { Erythemis carmelita } \\
\text { Erythrodiplax nigricans } \\
\text { Micrathyria longifasciata } \\
\text { Orthemis discolor } \\
\text { Pantala flavescens } \\
\text { Argentagrion ambiguum } \\
\text { Homeoura lindneri } \\
\text { Homeoura nepos } \\
\text { Ischnura capreolus }\end{array}$ & $\begin{array}{l}\text { Winter: } \\
\text { Micrathyria spuria ind } \\
\text { Tramea cophysa ind } \\
\text { Telebasis willinki ind } \\
\text { Acanthagrion lancea excl } \\
\text { Lestes minutus exc } \\
\text { Miathyria marcella } \\
\text { Argentagrion ambiguum } \\
\text { Homeoura nepos } \\
\text { Ischnura capreolus } \\
\text { Telebasis obsoleta }\end{array}$ \\
\hline $\begin{array}{l}\text { Grassy temporary } \\
\text { wetlands }\end{array}$ & $\begin{array}{l}\text { Variable in size, temporary, } \\
\text { still water, including } \\
\text { pools and flooded } \\
\text { short-grassland. Clayey } \\
\text { substrate. High grass cover, } \\
\text { sparse aquatic macrophyte } \\
\text { growth (increasing with } \\
\text { permanence). }\end{array}$ & $\begin{array}{l}\text { Spring-summer-autumn: } \\
\text { Micrathyria spuria ind } \\
\text { Orthemis nodiplaga }{ }^{\text {ind }} \\
\text { Edonis helena excl } \\
\text { Lestes minutus excl } \\
\text { Coryphaeschna adnexa } \\
\text { Coryphaeschna perrensi } \\
\text { Brachymesia herbida } \\
\text { Erythemis credula } \\
\text { Erythemis vesiculosa } \\
\text { Erythrodiplax nigricans } \\
\text { Orthemis discolor } \\
\text { Pantala flavascens } \\
\text { Acanthagrion lancea } \\
\text { Argentagrion ambiguum } \\
\text { Homeoura lindneri } \\
\text { Homeoura nepos }\end{array}$ & $\begin{array}{l}\text { Winter: } \\
\text { Coryphaeschna } \\
\text { adnexa excl } \\
\text { Lestes spatula excl } \\
\text { Erythrodiplax } \\
\text { paraguayensis } \\
\text { Argentagrion ambiguum } \\
\text { Homeoura lindneri } \\
\text { Homeoura nepos }\end{array}$ \\
\hline
\end{tabular}


Table 3. Continued.

\begin{tabular}{|c|c|c|c|}
\hline Wetland types & Description & Associate & species \\
\hline $\begin{array}{l}\text { Wooded temporary } \\
\text { wetlands }\end{array}$ & $\begin{array}{l}\text { Variable in size, temporary, } \\
\text { still water, including } \\
\text { pools, ponds and extensive } \\
\text { seasonally flooded } \\
\text { wooded savannahs. } \\
\text { Clayey substrate. Tall } \\
\text { woody vegetation with } \\
\text { abundant shade. Low } \\
\text { aquatic vegetation } \\
\text { cover (increasing with } \\
\text { permanence). }\end{array}$ & $\begin{array}{l}\text { Spring-summer-autumn: } \\
\text { Micrathyria tibialis ind } \\
\text { Micrathyria hypodidyma ind } \\
\text { Acanthagrion ascendens }{ }^{\text {ind }} \\
\text { Telebasis obsoleta ind } \\
\text { Aphylla distinguenda excl } \\
\text { Nephepeltia aequisetis excl } \\
\text { Tholymis citrina excl } \\
\text { Coryphaeschna adnexa } \\
\text { Coryphaeschna perrensi } \\
\text { Rhionaeschna bonariensis } \\
\text { Diastatops intensa } \\
\text { Erythemis attala } \\
\text { Erythemis carmelita } \\
\text { Erythemis mithroides } \\
\text { Erythemis plebeja } \\
\text { Erythemis vesiculosa } \\
\text { Macrothemis lauriana } \\
\text { Acanthagrion lancea } \\
\text { Homeoura lindneri }\end{array}$ & $\begin{array}{l}\text { Winter: } \\
\text { Telebasis willinki ind } \\
\text { Erythemis plebeja } \text { excl }^{\text {Erythrodiplax }} \\
\text { paraguayensis } \\
\text { Micrathyria longifasciata } \\
\text { Acanthagrion lancea } \\
\text { Ischnura capreolus } \\
\text { Telebasis obsoleta }\end{array}$ \\
\hline
\end{tabular}

\title{
ANISOPTERA
}

\begin{abstract}
AESHNIDAE
Anax amazili (Burmeister, 1839) Figure 5a Rare

Largest species in the region. General body colouration green with various dark brown or black markings. Face greenish yellow with black or brown triangle bordered by yellow on frons and often a small blue or brownish triangle on each side. In FW, upper sector of arculus shorter than lower sector and vein $\mathrm{RP}_{2}$ with a marked convex bend at distal end of PS (Figure 15g). HW of male lacks anal triangle and anal angle. HW: 45-52. AB: 4755. Widely distributed in the Americas, typically found around lentic habitats. We only recorded a single individual flying above a flooded short-grassland near the Paraguay River in May.
\end{abstract}

\section{Coryphaeschna adnexa (Hagen, 1861) Figure 5b-e Frequent (SSA), Occasional (winter)}

Face blue in male; mostly green, sometimes with blue, in female. Black T-spot on frons extends onto anterior surface and fills transverse groove on dorsal side. Thorax predominantly green with narrow brown lines along sutures, $\mathrm{AB}$ dark brown to black with green rings (narrow in male) (Tennessen, 2001; Von Ellenrieder, 2010). Male epiproct less than half as long as cerci (Figure 15i). Male - HW: 39-42. AD: 48-53. Female - HW: 41-45. AD: 52-57. Widespread in the Americas. In Neembucú, found in a variety of habitats. Generally recorded flying around 1-1.5 $\mathrm{m}$ above ground far from water in areas with relatively low mean vegetation height or along edge of wooded areas. Present year-round but more common in SSA, prefers high temperatures and sunny conditions.

\section{Coryphaeschna perrensi (McLachlan, 1887) Figure 5f-i Frequent}

Male easily recognised by entirely red body colouration, face orange to red. Female colouration differs from widespread red morph found elsewhere: thorax green with a reddish-brown stripe along the middorsal ridge and posterior margins; $\mathrm{AB}$ mostly reddish-brown with green to blue patches, face reddish-brown, postfrons light blue without black $\mathrm{T}$ spot, black posteriorly and 

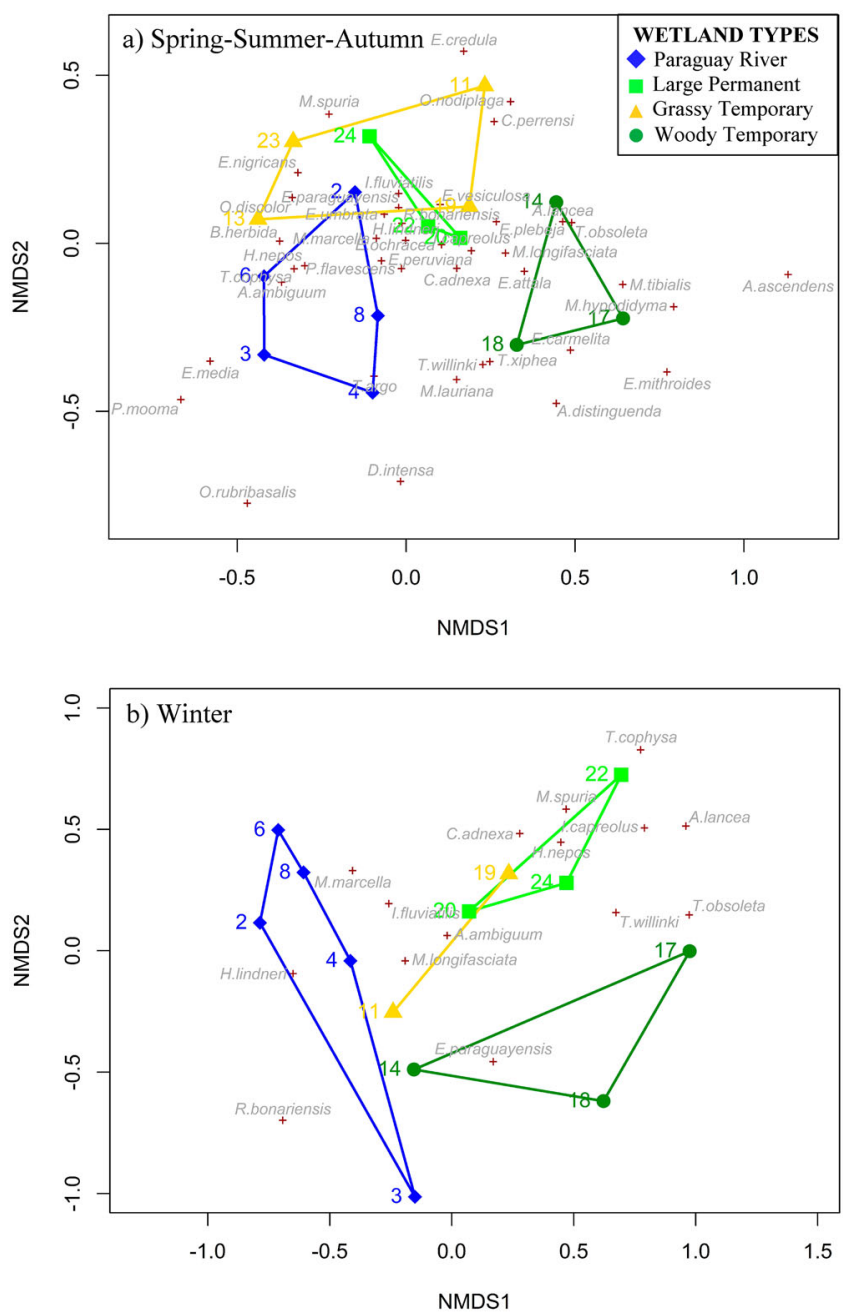

Figure 4. NMDS ordination plot showing the association between species and wetland habitats in central Ñeembucú in (a) spring-summer-autumn (SSA) and (b) winter, based on Bray-Curtis dissimilarity indices calculated from species presence per transect.

along base of vertex, rest of vertex light blue. Eyes maroon dorsally, mottled green and brown ventrally. Females also ca. $10 \mathrm{~mm}$ larger than previously recorded. Male - TL: ca. 63. HW: ca. 45. Female - TL: 70-76. HW: 50-54. Widespread in Neotropics. In Neembucú, found in a variety of habitats but prefers edges of wooded habitats near permanent waterbodies, scarce in urban areas. Generally recorded within $100 \mathrm{~m}$ of the water's edge flying about $1-2 \mathrm{~m}$ above the ground over terrestrial vegetation, especially patrolling the forest/thicket edge, prefers high temperatures and sunny conditions. Present summer and autumn.

\section{Coryphaeschna viriditas Calvert, 1952 Figure 5j, k Rare}

Face, eyes and thorax bright green, AB black and green. Black T spot on postfrons. Thorax with dark mesepisternal spot, outer margin convex in female. Male with epiproct more than half of cerci length (Figure 15j). Male — TL: ca. 80. HW: 50-56. Female — TL: ca. 83. HW: 50-62. Widespread across the Americas. Recorded in the Ñeembucú Wetlands, patrolling the gallery forest edge, near large permanent wetlands during autumn. 

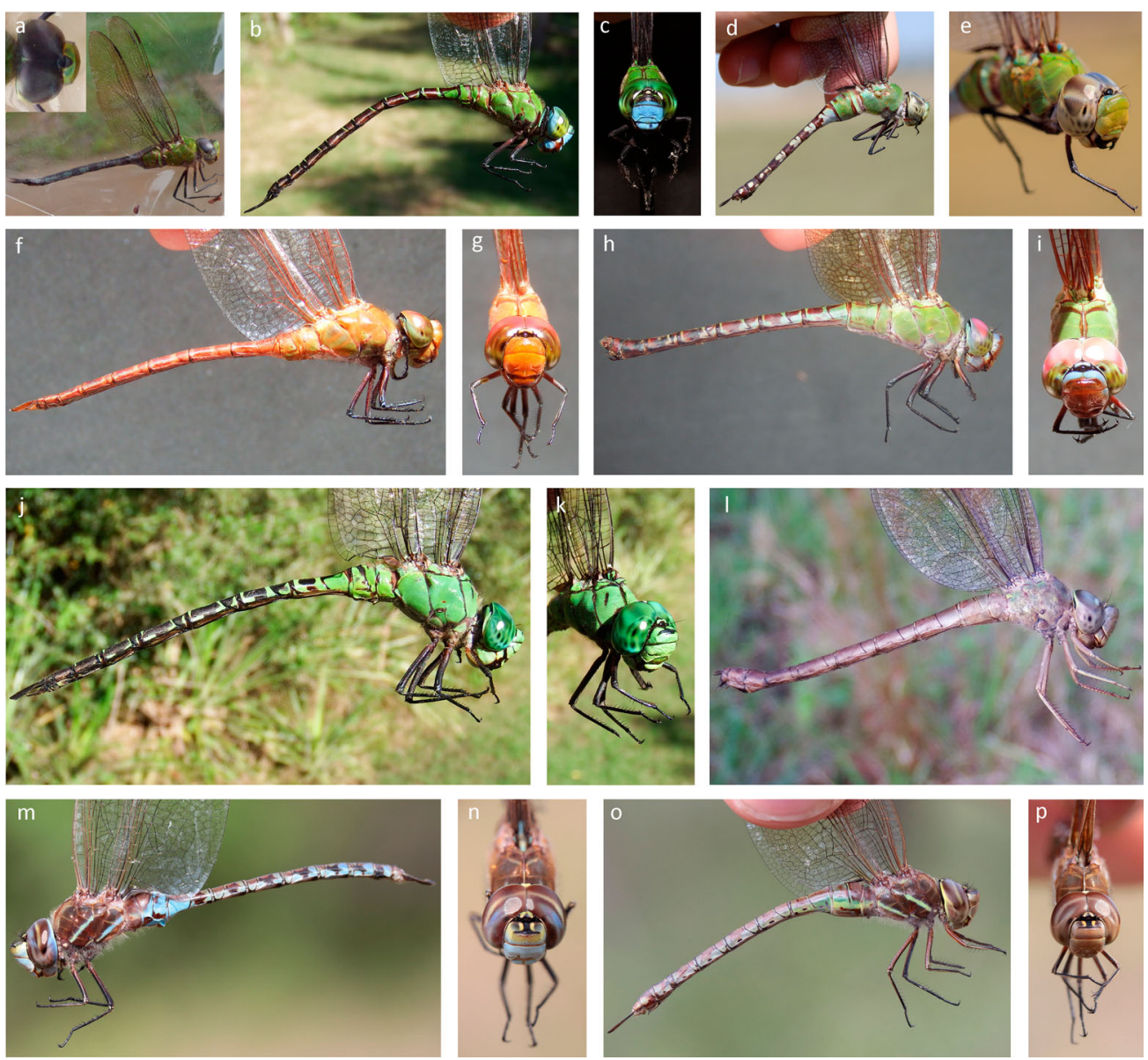

Figure 5. Aeshnidae of Ñeembucú: (a) Anax amazili; (b, c) Coryphaeschna adnexa (male); (d, e) Coryphaeschna adnexa (female); (f, g) Coryphaeschna perrensi (male); (h, i) Coryphaeschna perrensi (female); (j, k) Coryphaeschna viriditas (male); (1) Gynacantha convergens (female); (m, n) Rhionaeschna bonariensis (male); (o, p) Rhionaeschna bonariensis (female).

\section{Gynacantha convergens Förster, 1908 Figure 51 Rare}

Generally brown, brown-tinged wings to or slightly beyond first antenodal crossvein. In female, distance between lateral and ventral carinae on S3 at level of transverse carina narrowed to about half its width posterior to this point. S3 of male constricted at base. Female sternum of S10 with a sclerotised posterior process bearing two long apical spines (Figure 15c). Anterior process of anterior hamule upturned and separated from base by a deep groove (Figure 15d). HW: 38-42. AB: 42-25. Restricted to the Chaco and Yungas in Bolivia, Paraguay and Argentina (Von Ellenrieder, 2010). Recorded patrolling low over ground at clearing in Chaco thicket near a small shaded pool in the Paraguay River ecosystem during summer. Observed depositing eggs into a hole in mud adjacent to the pool prior to heavy rains.

\section{Rhionaeschna bonariensis (Rambur, 1842) Figure 5m-p Occasional (SSA), Freq. (winter)}

Brown and light blue or green with two diagonal stripes on pterothorax. Sternum of S1 with conical tubercle (Figure 15e). Postfrons with horizontal 'H-spot'. Cerci of male with basal outer white spots. Female with pale yellow mediolongitudinal stripe on dorsum of S2. TL: 50-58. HW: 33-40. Distributed across south-eastern South America. In Ñeembucú, associated with the 
Paraguay River ecosystem, occurring in a variety of habitats but especially along the river. Usually within $110 \mathrm{~m}$ of a water body in areas with dense terrestrial and/or aquatic macrophyte cover. Prefers cooler temperatures. Present late autumn and winter.

\section{GOMPHIDAE}

\section{Aphylla distinguenda (Campion, 1920) Figure 6a, b Occasional}

$\mathrm{AB}$ gradually changing colour from dark brown below and light green above on anterior segments to reddish brown posteriorly. Thorax dark brown with two pairs of bold pale green lateral stripes and antehumeral stripes. Face mostly dark brown, frons with white to pale blue dorsal bar. Male cerci thick, bent sharply inward near middle and bear a strong tooth on inner surface proximal to bend (Figure 16a). VL with V-shaped excision extending half of its length, base of excision rounded, angle between lobes $90^{\circ}$ and lateral lobes broadly rounded (Figure 16c) (Belle, 1992). HW: 33-35. AB: ca. 44. Restricted to Paraná-Paraguay basin. In Ñeembucú, found exclusively
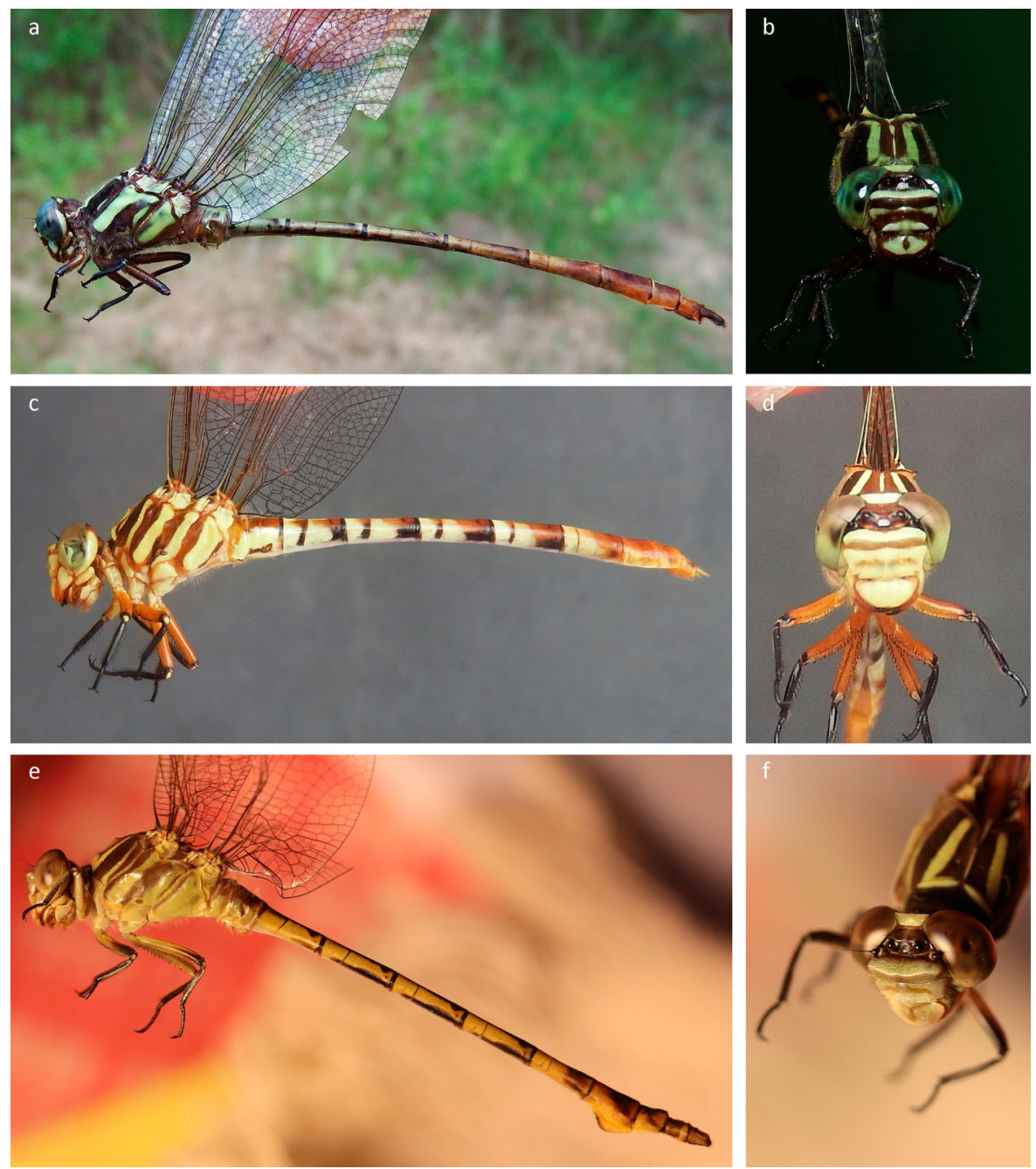

Figure 6. Gomphidae of Ñeembucú: (a, b) Aphylla distinguenda (male); (c, d) Aphylla theodorina (female); and (e, f) Phyllocycla argentina (male). 
in wooded habitats (canopy 4-6 m) near the Paraguay River, particularly flooded Chaco thicket, where it can become common, but also observed in vegetated urban areas. Perches or patrols at ca. $1 \mathrm{~m}$ high over flooded ground, especially along thicket edges. Prefers high temperatures. Present summer and early autumn

*Aphylla theodorina (Navás, 1933) Figure 6c, d Rare

Adult male predominantly dark brown. Female and immature with abdominal segments pale yellow, S1-3 reddish brown dorsally, S4-7 with rings along transverse carinae and distal margins that are reddish-brown above and black below, posterior segments becoming entirely reddish brown. Thorax reddish brown, with three pairs of bold pale-yellow stripes laterally and two pairs dorsally, pale stripes along middorsal carina, anterior and posterior margins. Face mostly pale yellow with dark brown on antefrons, clypeus and vertex, anterior part of postclypeus mostly pale. Costal vein bright yellow. Male cerci with fringe of long black hairs along inner margin (Figure 16b). VL with V-shaped excision for $1 / 2$ to $3 / 5$ its length, angle between lobes 60-90 and lobes broadly rounded (Figure 16d) (Belle, 1992). HW: ca. 33. AD: 40-42. New country record. Widely distributed in South America (Bedê et al. 2015). In Neembucú, all three records were made over grassland areas in the Neembucú Wetlands during hot summer weather.

*Phyllocycla argentina (Hagen in Selys, 1878) Figure 6e, f Rare

Body colour mostly dull yellow to olive-green with black along dorsum and venter of S3-6. Thorax, in dorsal view, with pale stripes in antehumeral region and along anterior margin; in lateral view, with multiple oblique diffuse brown stripes. Face entirely pale yellow. Male with lateral flange on S8 as wide as 0.2 of its length, cerci with mediobasal tooth in dorsal view and ventrobasal carina in lateral view. VL with rounded lobes (De Selys Longchamps, 1878). Male - HW: 29-33. AB: ca. 38. New country record. Distributed across south-eastern South America as far north as central Brazil. In Ñeembucú, we made a single record at a temporary grassy pool after a period of heavy rains during autumn.

\section{LIBELLULIDAE}

Brachymesia herbida (Gundlach, 1889) Figure 7a, b Frequent

Thorax yellow to dull green, AB yellow, S4-10 with black triangles extending from posterior margin to mid-point and black stripe extending further anterioly along middorsal carina. Frons and vertex whitish with brown markings. Wings heavily stained with amber along anterior costal margin, central part and apex, veins dark brown. S1-3 greatly swollen in lateral view. Widely distributed throughout the Americas. In Neembucú, usually found along edge of the Paraguay River but also large lentic waterbodies in the Neembucú Wetlands. Hawks insects from a perch ca. $1 \mathrm{~m}$ off the ground within a few metres of the water's edge and generally with low vegetation (ca. $0.5 \mathrm{~m}$ ) and/or bare ground (ca. $40 \%$ ). Present summer and autumn.

\section{Diastatops intensa Montgomery, 1940 Figure 7c, d Frequent}

Wings black with yellow or scarlet patch on HW base, heavily wrinkled. Costa of FW sigmoid with concave indentation between base and nodus. Supratriangle crossed. AB orange to scarlet, thorax black. Eyes uniquely separated. Male - TL: ca. 30. AB: ca. 23. Female - TL: ca. 22. AB: ca. 23. Widely distributed in South America. In Neembucú, recorded at edge of large permanent habitats, including the Paraguay River and permanent large wetlands, but also flooded woodland and gallery forest edge. Usually close to water's edge (ca. $15 \mathrm{~m}$ ) but also in gallery forest with bromeliad undergrowth. Perches low to ground $(<0.3 \mathrm{~m})$, sometimes on floating mats of Salvinia. Present SSA. 

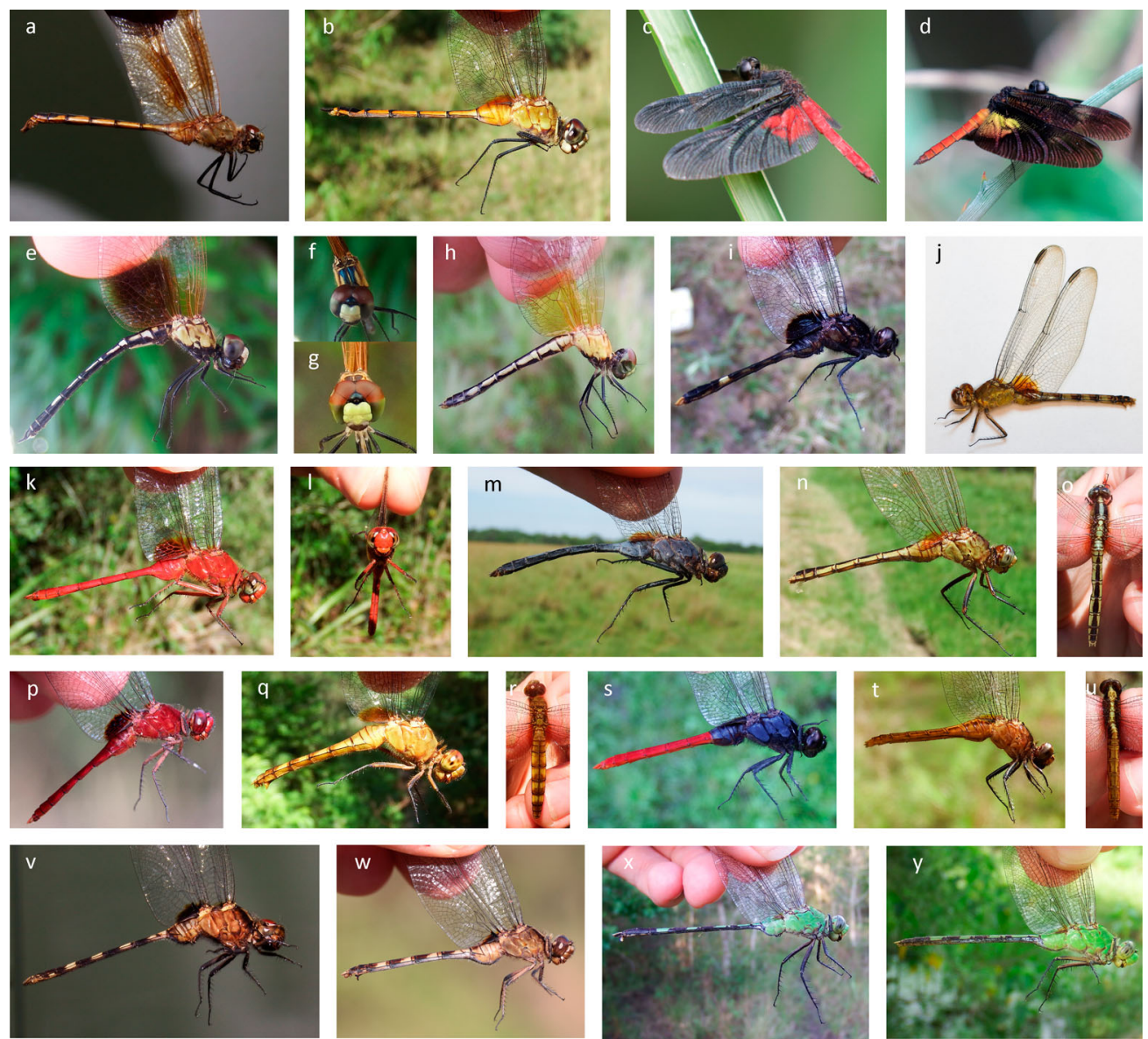

Figure 7. Libellulidae (Brachymesia - Erythemis) of Ñeembucú: (a) Brachymesia herbida (male); (b) Brachymesia herbida (female); (c) Diastatops intensa (red morph, male); (d) Diastatops intensa (yellow morph, male); (e, f) Edonis helena (male); (g, h) Edonis helena (female); (i) Erythemis attala (male); (j) Erythemis attala (female); (k, 1) Erythemis carmelita (male); (m) Erythemis credula (male); (n, o) Erythemis credula (female); (p) Erythemis mithroides (male); (q, r) Erythemis mithroides (female); (s) Erythemis peruviana (male); (t, u) Erythemis peruviana (female); (v) Erythemis plebeja (male); (w) Erythemis plebeja (female); (x) Erythemis vesiculosa (male); and (y) Erythemis vesiculosa (female).

*Edonis helena Needham, 1905 Figure 7e-h Occasional

AB black with yellow lateral marking on S1-7. Thorax, in lateral view, yellow with black along base, dorsum yellow with dark metallic blue-black postdorsal stripes. HW base broadly widened, basal spot reaching distal end of triangle, dark brown (male) or yellow (female). FW with last antenodal complete and two or more bridge crossveins. Distal half of male cerci upturned (Figure 19a) (Garrison et al., 2006). Female cerci convergent distally, VL V-shaped with thick distal margin (Figure 19b, c). Male — TL: 29-32. Female - TL: 26-32, HW: 18-21. New country record. Poorly known monotypic genus with narrow distribution along the Paraná River, here extended to the Lower Paraguay. We exclusively recorded this species perched in open short-grassland (ca. $0.5 \mathrm{~m})$, mostly far from water (ca. $100 \mathrm{~m}$ ). Present in spring and summer.

\section{Erythemis attala (Selys in Sagra, 1857) Figure 7i, j Occasional}

Body colour black with whitish dorsal markings on S7 (adult male) or greenish-brown with distal portion of S4-7 dark brown (female and immature). Lacks antehumeral stripes. AB shorter 
than HW, S4 slightly constricted in dorsal view, S1-3 moderately widened in lateral view. HW basal spot reaches cubito-anal crossvein and base of triangle, and covers a small basal region or marginal cells to anal angle (Rodríguez, Sarmiento, \& González-Soriano, 2015). TL: 4049. HW: 35-38 (male) and 32-35 (female). Widespread in Neotropics. In Ñeembucú, prefers wooded habitats (canopy $4-6 \mathrm{~m}$, non-flooded) within ca. $60 \mathrm{~m}$ of water's edge, absent from grassy wetlands and urban areas. Perches ca. $1 \mathrm{~m}$ above ground. Present SSA.

\section{*Erythemis carmelita Williamson, 1923 Figure 7k, 1 Occasional}

Body colour scarlet to reddish-brown (adult male) or greenish-brown, with dark brown spots on S1-3, dorsal and lateral markings on S3-7 and covering dorsal and lateral surfaces on S8-10 (female) (Rodríguez et al., 2015; Williamson, 1923). Thorax lacks antehumeral stripes, legs mostly pale. AB shorter than HW, S4 notably constricted in dorsal view, S1-3 considerably widened in lateral view. Male - TL: ca. 47. HW: 33-35. New country record. Localised distribution across tropical South America. Recorded in the Neembucú Wetlands in or along the edge of wooded habitats with bromeliad undergrowth near lentic waterbodies, perches ca. $0.35 \mathrm{~m}$ above ground. Recorded during autumn.

\section{*Erythemis credula (Hagen, 1861) Figure 7m-o Frequent}

Body colour grey-blue to black (adult male) or ochraceous to brown with pale middorsal stripe extending across thorax to S3 and black antehumeral stripes (female and immature). AB with black middorsal stripe widening distally. AB shorter than HW, S4 slightly to moderately constricted in dorsal view, S1-3 moderately widened in lateral view. HW dark basal spot does not reach first antenodal crossvein but extends beyond cubito-anal crossvein (sometimes to the supplementary anal vein) to penultimate or marginal row of cells in anal field (Rodríguez et al., 2015) (Figure $18 \mathrm{~m}$ ). Male - TL: 38-44. HW: 25-32. Female — TL: 41-42. HW: 28-31. Widespread in South America but new country record. In Neembucú, found exclusively around lentic waterbodies. Usually recorded close to or over water in areas with mixed terrestrial and aquatic vegetation cover with low height (often floating), perches ca. $25 \mathrm{~cm}$ above substrate. Present spring and summer.

\section{Erythemis mithroides (Brauer, 1900) Figure 7p-r Frequent}

Body colour red to reddish-brown (mature male) or ochraceous, S4-7 paler on proximal half, darker distally, with narrow dark-brown to black margins (female and immature). Thorax lacks antehumeral stripes. AB shorter than HW, dorsoventrally flattened, S4 not constricted in dorsal view, S1-3 moderately widened in lateral view. HW basal spot reaching beyond cubito-anal crossvein (sometimes reaching supplementary anal vein) (Rodríguez et al., 2015). HW: 29-35. AB: 21-31. Widespread in Neotropics. In Ñeembucú, mostly found within $100 \mathrm{~m}$ of water's edge around lentic waterbodies in more shaded wooded habitats (canopy 4-6 m), particularly in the Ñeembucú Wetlands, but also emergent meadows along the Paraguay River. Perches up to $2.5 \mathrm{~m}$ above ground. Present SSA.

\section{Erythemis peruviana (Rambur 1842) Figure 7s-u Abundant}

Adult male distinctly red from S4-10, rest of body dark metallic blue. Female and immatures body colour brown with pale yellow dorsal stripe from thorax to S3, dark antehumeral stripes; S3-10 pale dorsally, bordered by brown stipes with thin brown middorsal stripe and short dark brown horizontal stripes subterminal to S3-7. AB shorter than HW, dorsoventrally flattened, S4 not constricted in dorsal view, S1-3 moderately widened in lateral view. HW basal cloud small, not reaching first antenodal or anal angle vein (Rodríguez et al., 2015). Male — TL: ca. 44. HW: 26-32. Female - HW: 27-31. AB: 23-28. Widespread in the Americas. In Neembucú, found in all habitats. Usually within $10 \mathrm{~m}$ of water, including flooded ground, where it perches ca. $35 \mathrm{~cm}$ above substrate in areas with high terrestrial and/or aquatic vegetation cover and low to moderate height. Prefers high temperatures. Present SSA. 


\section{Erythemis plebeja (Burmeister, 1839) Figure 7v, w Common (SSA), Rare (winter)}

$\mathrm{AB}$ with alternating cream and dark brown patches in lateral view. Thorax brown with dark brown antehumeral stripes. Old males completely black body. AB about equal in length or longer than HW, markedly constricted in dorsal view. HW basal spot reaches beyond cubitoanal crossvein and anal angle vein (Rodríguez et al., 2015). TL: 47-52. HW: 30-36. Widespread throughout the Americas. Mostly found at wooded temporary wetlands, especially flooded Chaco thicket, and large permanent wetlands in the Ñeembucú Wetlands, also in thicket along Paraguay River. Usually close to or over water, including flooded ground, where it perches ca. $0.5-1 \mathrm{~m}$ above substrate, in areas with high terrestrial and/or aquatic vegetation cover and moderate height. Prefers high temperatures. Present year-round.

\section{Erythemis vesiculosa (Fabricius, 1775) Figure 7x, y Abundant}

Head and thorax predominantly green; S4-7 green, with black or brown markings on posterior parts, S8-10 black or brown. AB longer than HW and considerably constricted at S4 in dorsal view. In lateral view, S1-3 considerably widened with blister-like extensions. HW basal spot very small, not reaching first antenodal, cubito-anal crossveins or anal angle (Rodríguez et al., 2015) (Figure 181). Discoidal field contains three rows of cells. TL: 57-64. HW: 3641. Widespread across the Americas. In Neembucú, found in all habitats, usually within $90 \mathrm{~m}$ of a water body, flying ca. $0.5-1.5 \mathrm{~m}$ above low terrestrial vegetation in areas with little shade (often following people or livestock to predate fleeing insects). Prefers high temperatures. Present SSA.

\section{Erythrodiplax media Borror, 1942 Figure 8a Occasional}

Adult male body colour blue-black, AB base with light blue pruinescence up to S7. Adult female with brownish black or bluish black face, thorax pale brown to reddish brown. Immature yellow with dark brown markings on AB. HW with prominent dark brown to black (males) or amber (female) basal spot, reaching first antenodal crossvein and almost reaching triangle. FW triangle crossed. Viewed laterally, lateral lobes of vesica spermalis not more than one third as wide as apex of terminal segment; median process extends beyond apex of median lobes by a distance equal or greater than length of lateral lobes and not bilobed (Figure 19i). VL generally more or less rounded in lateral view with base less than half as wide as its length, shorter than S9 and convex dorsoposterior margin (Figure 19n). TL: 26-32. HW: 21-26 (male) and 19-24 (female) (Borror, 1942). Distributed between Bolivia, Paraguay, N Argentina and SE Brazil. Recorded twice, exclusively along the Paraguay River, in wooded patches with shade, 5-10 $\mathrm{m}$ from the water's edge, $0.5 \mathrm{~m}$ above the ground, at very high temperatures. Present SSA.

\section{Erythrodiplax nigricans (Rambur, 1842) Figure 8b-e Common}

Body colour black with pale patch on S7, dark reddish-brown thorax and metallic blue frons and vertex (adult male) or olive green to yellow, black lateral markings on S4-10, reddish-brown markings and black dorsal stripe on $\mathrm{S} 8-10, \mathrm{AB}$ white ventrally, thorax darker brown dorsally with pale middorsal stripe (female and immature). Cerci white. HW with a small orange brown basal spot, barely visible in males. PS brown with distinct dark anterior and posterior borders; mature specimens with faint orange-brown area posterior to PS. FW with at most $81 / 2$ antenodal crossveins, triangle and subtriangle crossed, radial planate with one row of cells, apical planate changing from one to two rows of cells distally (Figure 18j). Penultimate spine at outer angle of hind femur $1 / 3$ length of ultimate spine or less (beware of broken spines!). In lateral view, inner branch of hamule bent rather abruptly caudad often obscuring the inner branch (Figure 19e). Median process of vesica spermalis extends slightly or not at all beyond apex of median lobes and lacks tuft of bristles at its tip, posterior lobe well developed (Figure 19j). In lateral view, VL shorter than S9, generally rounded and more than half as wide at base than long (Figure 19o) (Borror, 1942; Garrison et al., 2006). Male - HW: 19-25. Female - TL: ca. 38. HW: 22-29. 

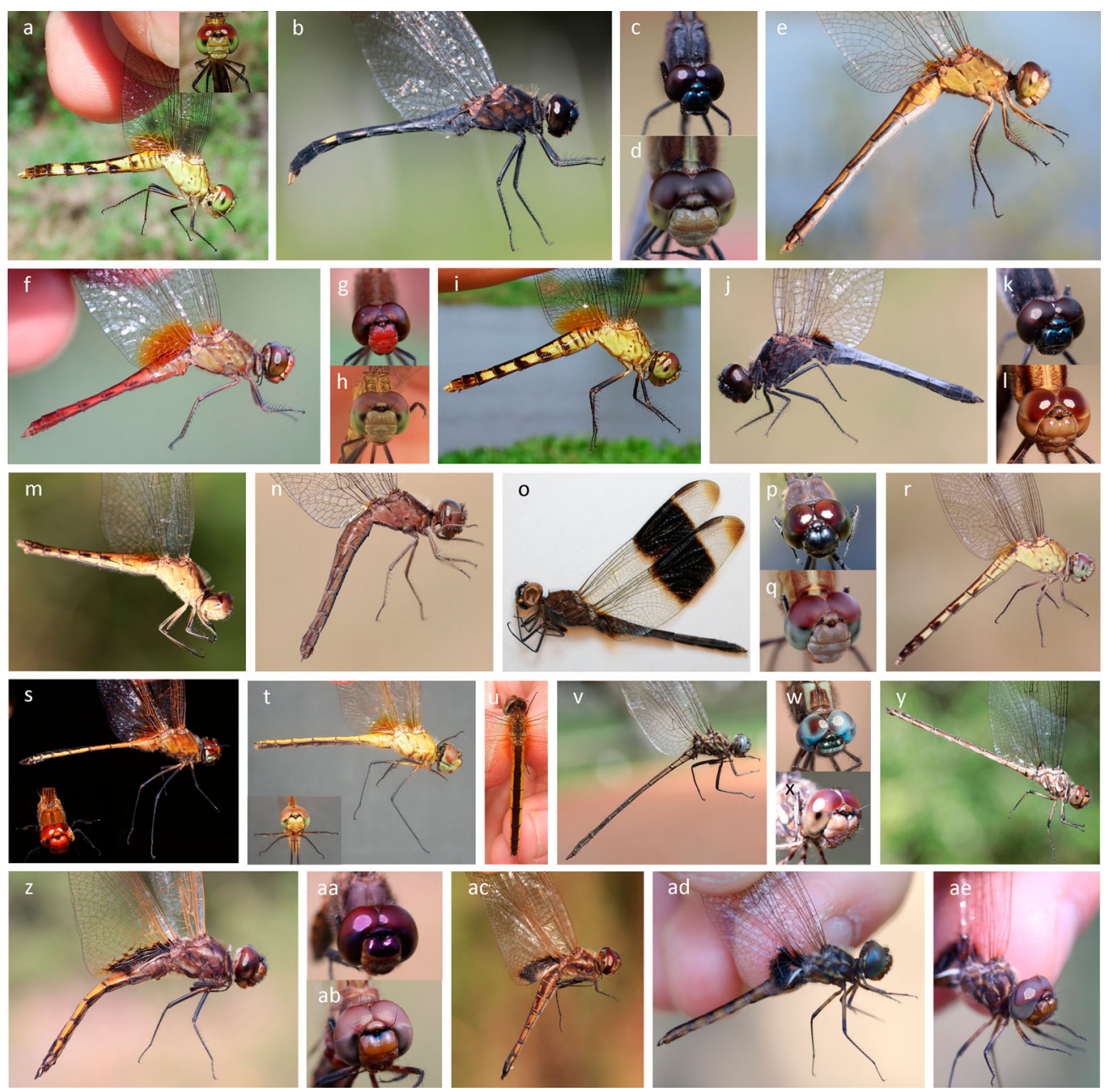

Figure 8. Libellulidae (Erythrodiplax - Miathyria) of Neembucú: (a) Erythrodiplax media (female); (b, c) Erythrodiplax nigricans (male); (d, e) Erythrodiplax nigricans (female); (f, g) Erythrodiplax ochracea (male); (h, i) Erythrodiplax ochracea (female); (j, k) Erythrodiplax paraguayensis (male); (1, m) Erythrodiplax paraguayensis (female, yellow morph); (n) Erythrodiplax paraguayensis (female, brown morph); (o, p) Erythrodiplax umbrata (male); (q, r) Erythrodiplax umbrata (female); (s) Idiataphe longipes (male); (t, u) Idiataphe longipes (female); (v, w) Macrothemis lauriana (male); (x, y) Macrothemis lauriana (female); (z, aa) Miathyria marcella (male), (ab, ac) Miathyria marcella (female); (ad, ae) Miathyria simplex (female).

Restricted to Pampas biome. More common in the Paraguay River ecosystem than the Neembucú Wetlands. Prefers open habitats, including grassy temporary wetlands and emergent meadows, with high vegetation cover but low height $(<0.5 \mathrm{~m})$. Forages ca. $10 \mathrm{~cm}$ above the ground, usually within ca. $30 \mathrm{~m}$ of water's edge. Present in urban areas. Prefers mild to hot temperatures. Present SSA, abundance peaks in autumn.

\section{Erythrodiplax ochracea (Burmeister, 1839) Figure 8f-i Common (SSA), Rare (Winter)}

Body colour mostly red with more olive thorax (adult male) or yellow, olive green or brown (female and immature) with darker colouration (black in mature females) on middorsal stripe and distal half of $\mathrm{AB}$ segments and marbling on mesepisterna. Amber cloud at base of HW reaching triangle distinct among Erythrodiplax species. FW triangle crossed or free (Figure 18k). Anal loop with about 15-18 cells. Inner branch of hamule less than a quarter the length of outer branch. 
Distal segment of vesica spermalis long and cylindrical, with complex and largely hidden distal lobes, gradually widening to rounded or bluntly angulated tip (Figure 19k). In lateral view, VL triangular with nearly straight sides and pointed apex (Figure 19p). In female, posterior lobe of prothorax quadratic and not narrowed distally, and penultimate spine at outer angle of hind femur at least 1/3 the length of ultimate spine. HW: 20-22. Widespread in Neotropics. In Neembucú, found in all habitats, usually with high vegetation cover of moderate height, and within ca. $30 \mathrm{~m}$ from the water's edge. Perches ca. $0.3 \mathrm{~m}$ above substrate. Prefers warm temperatures. Present year-round.

\section{Erythrodiplax paraguayensis (Förster, 1905) Figure 8j-n Abundant}

In adult male, AB light blue and pruinose with black tip, thorax blackish, frons and vertex metallic blue. Female and immature predominantly yellow to brown with dark antehumeral stripes and dorsal and posterolateral markings on AB segments (Borror, 1942). Wings hyaline, sometimes with small black basal spot on HW (Figure 17m), PS light grey with dark borders. FW triangle usually free. In lateral view, lateral lobes of vesica spermalis at least half as wide at base as at apex of terminal segment; median process extends beyond apex of median lobes to a distance at least equal to length of lateral lobes and not bilobed (Figure 191). Female cerci convex at tip, VL more or less rounded in lateral view (Figure 19q). HW: 15-20. Widespread across Neotropics. In Ñeembucú, found across a variety of habitats but particularly abundant in more open habitats with low canopy height (ca. $0.5 \mathrm{~m}$ ). Found up to $550 \mathrm{~m}$ from water's edge. Tolerates cool to very hot temperatures. Present year-round, abundance peaks from winter to spring.

\section{Erythrodiplax umbrata (Linnaeus, 1758) Figure 80-r Abundant}

Wings with distinctive black bands (adult male and homochromatic female) and/or tinged with brown, especially at apex. Body colour variable from yellow to reddish-brown, AB with black middorsal stripe and black patches on distal portion of S4-9, S10 black, thorax with dark humeral stripes. Cerci pale. Rspl with two rows of cells, Mspl with one row of more than six cells, radial planate absent. FW with at least $91 / 2$ antenodal crossveins, triangle and subtriangle crossed, vein MP of HW arises at anal angle of triangle (Figure 18i). Larger than other Erythrodiplax in the region. HW: 26-34. AB: 22-32 (Borror, 1942). Widespread in the Americas. More prevalent near the Paraguay River than in the Neembucú Wetlands but found in all habitats, preferring areas with relatively high terrestrial vegetation cover and moderate height, sometimes far from water, usually ca. $0.5 \mathrm{~m}$ above ground. Tolerates mild to high temperatures. Present SSA.

\section{Idiataphe longipes (Hagen, 1861) Figure 8s-u Occasional}

Body colour yellow to orange, $\mathrm{AB}$ with thick black parallel-sided middorsal stripe. Frons and vertex yellow to orange. Wings yellowish, veins yellow to orange. Legs long. HW: 30-33. AB: 25-28. Distributed throughout tropical South America. In Ñeembucú, recorded along edge of the river and large permanent wetlands, hawking insects from exposed perches ca. $1 \mathrm{~m}$ off the ground in open areas with large portion of bare ground and/or low vegetation. Prefers high temperatures. Recorded in spring and summer.

\section{Macrothemis lauriana Ris, 1913 Figure 8v-x Occasional}

Distinct long, thin cylindrical AB without widening of apical segments. AB patterned with thin black middorsal stripe bordered by pair of thin pale olive stripes, followed by a pair of black stripes, laterally light brown (female and immature) to black (adult male), black below. Thorax, dorsally with dark patch (metallic in adult male) on lower two-thirds of the central region, bordered by pale olive (male) or white (female and immature) extending to antehumeral region; laterally marbled with pale olive (male) or white (female), brown and black. Frons greenishwhite (adult male) or light brown with metallic stripe along posterior border (female), vertex 
metallic green (adult male) or light brown (female). Eyes blue (male) or red dorsally and brown ventrally (female). Male cerci blunt (Figure 19ac) (May, 1998). VL not projected ventrally (Figure 19ad). Male — TL: 52-55. HW: 36-37. AB: 42-44. Female — TL: 48-52. HW: 34-39. Occurs in Peru, Paraguay and Mato Grosso do Sul. In Neembucú, found exclusively along the Paraguay River (where it is frequently observed) and nearby temporary waterbodies, surrounded by wooded habitat (canopy ca. $1-3 \mathrm{~m}$ ), generally patrolling low (ca. $60 \mathrm{~cm}$ ) over substrate in sunny areas. Males usually within $20 \mathrm{~m}$ of water's edge, females further away. Prefer higher temperatures. Present SSA.

\section{Miathyria marcella (Selys in Sagra, 1857) Figure 8z-ac Abundant}

AB yellow with black middorsal stripe from S4-10, thorax and S1-3 brown with violet-blue pruinescence dorsally (adult male) or body mostly brown (female and immature), usually with two pale lateral thoracic stripes. Frons metallic violet (adult male), brown or olive (female and immature). HW extremely broad at base with dark basal patch (Figure 171), radial planate with five to seven cells (Figure 18b), wing veins orange. HW: 30-34. AB: 23-26. Widespread across temperate and tropical Americas. In Neembucú, found in all habitats. Usually flying 1-2 m above areas with low canopy $(0.5-1.8 \mathrm{~m})$, often gathering in large groups, especially on leeward side of structures (forest patches/buildings) during strong winds. Tolerates mild to high temperatures. Present year-round.

*Miathyria simplex (Rambur, 1842) Figure 8ad, ae Rare

Body colour red (adult male) or thorax brown with darker lateral markings and $\mathrm{AB}$ yellow laterally with black middorsal stripe (female and immature). HW broad at base with black basal patch reaching proximal side of triangle, proximal half with reddish veins and apical half hyaline with brown veins. Radial space of FW with three or four cells (Figure 18c). TL: 31-32. HW: 25-27. New country record. Widespread in Neotropics as far south as São Paulo. In Ñeembucú, we found two immature specimens in the interior of tall gallery forest and thicket (max. canopy $8-10 \mathrm{~m}$ ) in the Ñeembucú Wetlands ecosystem during summer and winter. Likely more prevalent than observed due to lack of surveys in forest interior.

\section{Micrathyria hypodidyma Calvert, 1906 Figure 9a-d Occasional}

Thorax black, laterally with two pale oblique stripes running from anteroventral to posterodorsal edges, dorsally with an elongated pale green spot on each side. AB black with distinct pale mark on S7, smaller spots on basal segments. Face white to light brown with metallic blue postfrons and vertex, eyes turquoise. FW triangle free, subtriangle two or three celled (Figure $18 \mathrm{~h}$ ). Male cerci approximately linear in lateral view, extending only slightly beyond epiproct (Figure 19s). Female with slender cerci (Figure 19u). TL: 35-38. HW: 26-27. Distributed throughout tropical South America. Recorded at lentic waterbodies in wooded habitats with a high canopy and partial shade, close to water's edge. Prefers mild temperature. Present autumn and winter.

\section{Micrathyria longifasciata Calvert, 1909 Figure 9e-h Common}

Thorax black, laterally with a single pale green oblique stripe running from anterodorsal to posteroventral edges, dorsally with pale stripes running adjacent to middorsal carina (only upper half in adult male) and posterior margin of mesepesternum, and two pale elongated spots on each side. In dorsal view, male AB narrowed at S4 and gradually widened at S7, cerci narrowed along basal third and widening again about two thirds the distance to apex. S7 with large pale dorsal mark. FW subtriangle and sometimes triangle crossed. HW: 24-25. AB: ca. 23. Distributed from Bolivia and Mato Grosso to N Argentina. Recorded in all habitats, generally close to water's edge (but up to $100 \mathrm{~m}$ ), in areas with high vegetation cover, moderate height and dappled shade (ca. $25 \%$ ). Perches up to $1.8 \mathrm{~m}$ off ground. Prefers mild to warm temperatures. Present year-round but abundance peaks in autumn. 

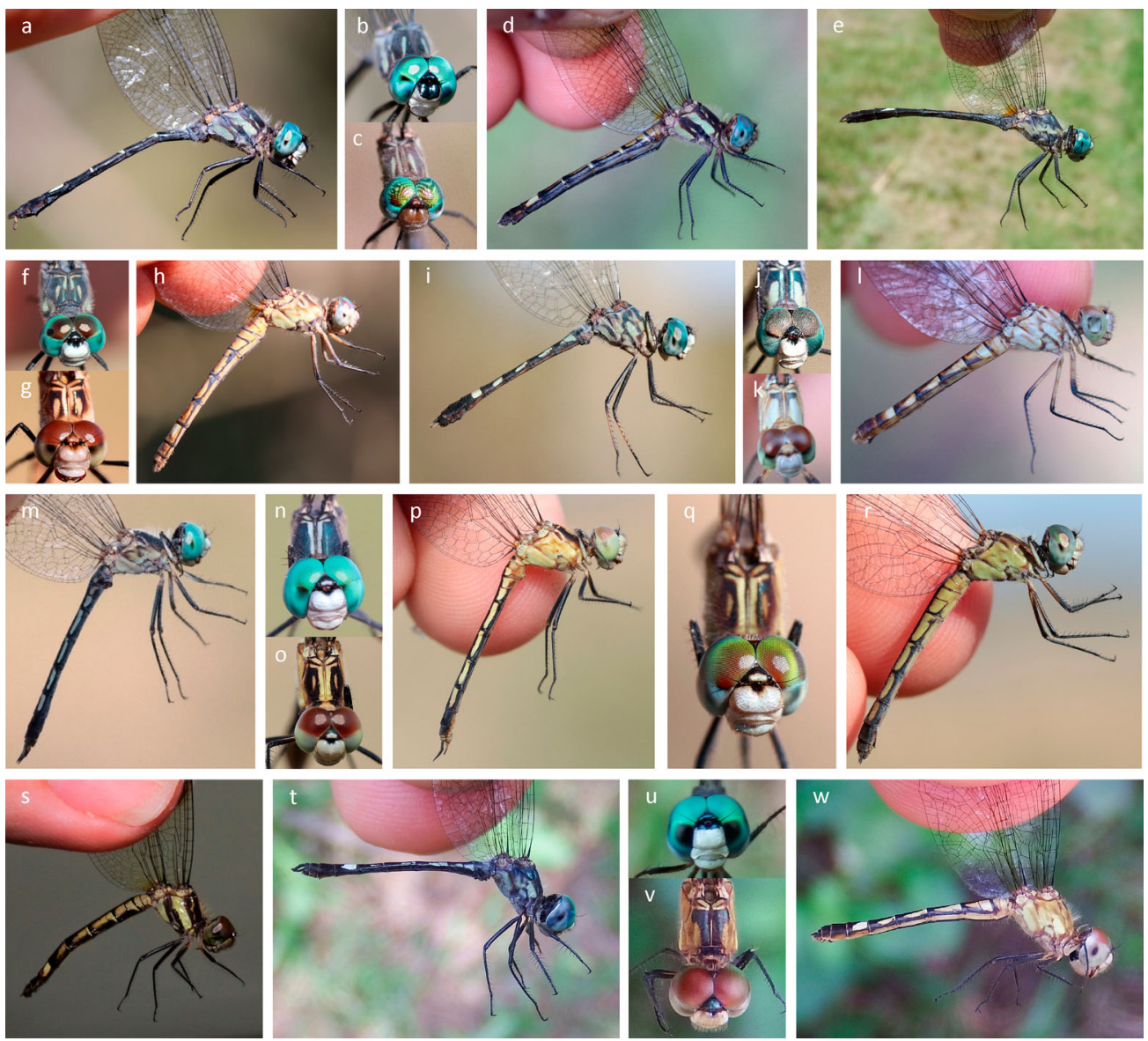

Figure 9. Libellulidae (Micrathyria - Nephepeltia) of Ñeembucú: (a, b) Micrathyria hypodidyma (male); (c, d) Micrathyria hypodidyma (female); (e, f) Micrathyria longifasciata (male); (g, h) Micrathyria longifasciata (female); (i, j) Micrathyria tibialis (male); (k, l) Micrathyria tibialis (female); (m, n) Micrathyria spuria (male, blue morph); (o, p) Micrathyria spuria (male, yellow morph); (q, r) Micrathyria spuria (female); (s) Micrathyria venezuelae (female); (t, u) Nephepeltia aequisetis (male); (v, w) Nephepeltia aequisetis (female).

\section{Micrathyria spuria (Selys, 1900) Figure 9m-r Common}

Blue and yellow colour morphs present. Thorax, laterally relatively plain with small dark markings (sometimes restricted to area around fossae); dorsally, pale stripe runs along middorsal carina and posterior margin. AB black dorsally with pale lateral markings on S1-7, not larger on S7. Frons white, vertex black with white tip. FW triangle and subtriangle free, HW anal loop foot shaped, with at least 10 cells (Figure 18e). Male cerci long (ca. $2.5 \mathrm{~mm}$ ), distally upturned with pale dorsal mark. HW: ca. 20. AB: 16-17. Distributed from Venezuela to Argentina. Strongly associated with large permanent wetlands and grassy temporary wetlands in the Neembucú Wetlands but also found in emergent meadows along the Paraguay River. Usually over or close to water in areas with open vegetation with high cover but low height (i.e. flooded short grassland). Perches ca. $0.3 \mathrm{~m}$ off substrate. Tolerates mild to high temperatures. Present yearround, abundance bimodal, peaking in winter and summer, coinciding with periods of highest rainfall. 


\section{Micrathyria tibialis Kirby, 1897 Figure 9i-1 Frequent}

Thorax with irregular marbled patterning laterally, metallic violet and pale green (adult male) or brown and pale yellow (female and immature). Dorsally, metallic violet (male) or brown (female) along middorsal carina and posterior margin, pale on anterior portions. AB black dorsally with pale markings from S3-7 (male) or S4-7 (female), most prominent on S7; S1-3 mostly pale in female. Head whitish with posterior margin of postfrons and vertex metallic blue (adult males) or brown (female and immature). FW triangle and subtriangle free. HW anal loop not foot-shaped, with at most nine cells (Figure 18f). HW: ca. 19. PS: ca. 2. Widely distributed in Neotropics. More common in the Neembucú Wetlands than near the Paraguay River. Strongly associated with wooded temporary wetlands but also found at large permanent wetlands and in emergent meadows. Often far from water in thicket with a tall canopy (3-6 m) and plenty shade (ca. 60\%), perches ca. $1 \mathrm{~m}$ off ground. Prefers warm to high temperatures. Present year-round, abundance peaks in summer and early autumn.

\section{*Micrathyria venezuelae De Marmels, 1989 Figure 9s Rare}

Body colour very similar to $M$. hypodidyma but labium yellow with black middle band. Female wing tips darkly tinged. FW with $9 \frac{1}{2}$ or $10^{1 / 2} 2$ antenodal crossveins, triangle usually crossed, subtriangle three celled. Hamule much larger than genital lobe, surpassing proximal margin of anterior lamina, not spiked. Male cerci bent ventrally in lateral view (Figure 19t). Female with thick cerci (Figure 19v). HW: 27-31. AB: 21-27. New country record. Widely distributed in tropical South America. We made a single record in Chaco thicket with moderately high canopy and mottled shade, ca. $80 \mathrm{~m}$ from the water's edge, perched $2 \mathrm{~m}$ above ground, during summer.

\section{Nephepeltia aequisetis Calvert, 1909 Figure 9t-w Rare}

Lateral thorax pale with dark stripes along sutures, widest along metapleural suture. AB black with pale green lateral markings on S3-7, most prominent on S7 (adult male) or S4-7 (female and immature), S1-3 entirely pale, S7-10 widened and flattened. Female pruinose. Similar to Micrathyria from which it can be separated by last antenodal complete and base of FW discoidal field one cell wide. Distinguished from other Nephepeltia species by possessing three cells in radial planate, base of FW discoidal field one cell wide, one cell between FW subtriangle and wing margin (Figure $17 \mathrm{~h}$ ) and male cerci with ventral tooth at about $3 / 4$ the distance to apex, and epiproct almost as long as cerci (Figure 19w) (Von Ellenrieder, 2014). HW: 1517. Distributed across the tropical South American interior. We collected two specimens from Chaco thicket (ca. $60 \mathrm{~m}$ from water, moderate canopy $(1-3 \mathrm{~m})$, ca. $17 \%$ shade, perched $0.2 \mathrm{~m}$ above ground) and a large permanent wetland in the Neembucú Wetlands during autumn and winter.

\section{Oligoclada pachystigma Karsch, 1890 Figure 10a Rare}

$\mathrm{AB}$ and thorax entirely dark blue, face mostly white, frons and vertex metallic blue. Tarsal claw with indefinite tooth (notched) located at about two thirds its length. Wings tinged brown, HW lacks basal spots. Triangle and subtriangle free, last antenodal crossvein complete. Paraproct of male nearly as long as cerci (Figure 19z). VL formed by two short rounded and thickened lobes (Figure 19ab). HW: 17-22. AB: 14-18 (Borror, 1931). Widely distributed in tropical South America. A single specimen was collected on 20 December 2015 at the river's edge in Pilar.

*Oligoclada rubribasalis Von Ellenrieder \& Garrison, 2008 Figure 10b-e Occasional $\mathrm{AB}$ and thorax dark blue to light grey blue and pruinose with distinct orange-red dorsal spots on S2-3. Face white, frons and vertex metallic blue. Wings hyaline with, at most, 2-3 browntined cells on HW base. Epiproct of male slightly bifid at tip, extending to $3 / 4$ of cerci length (Figure 19x, y). VL deeply V-shaped (Figure 19aa). HW: 19-21. AB: 14-16. New country 

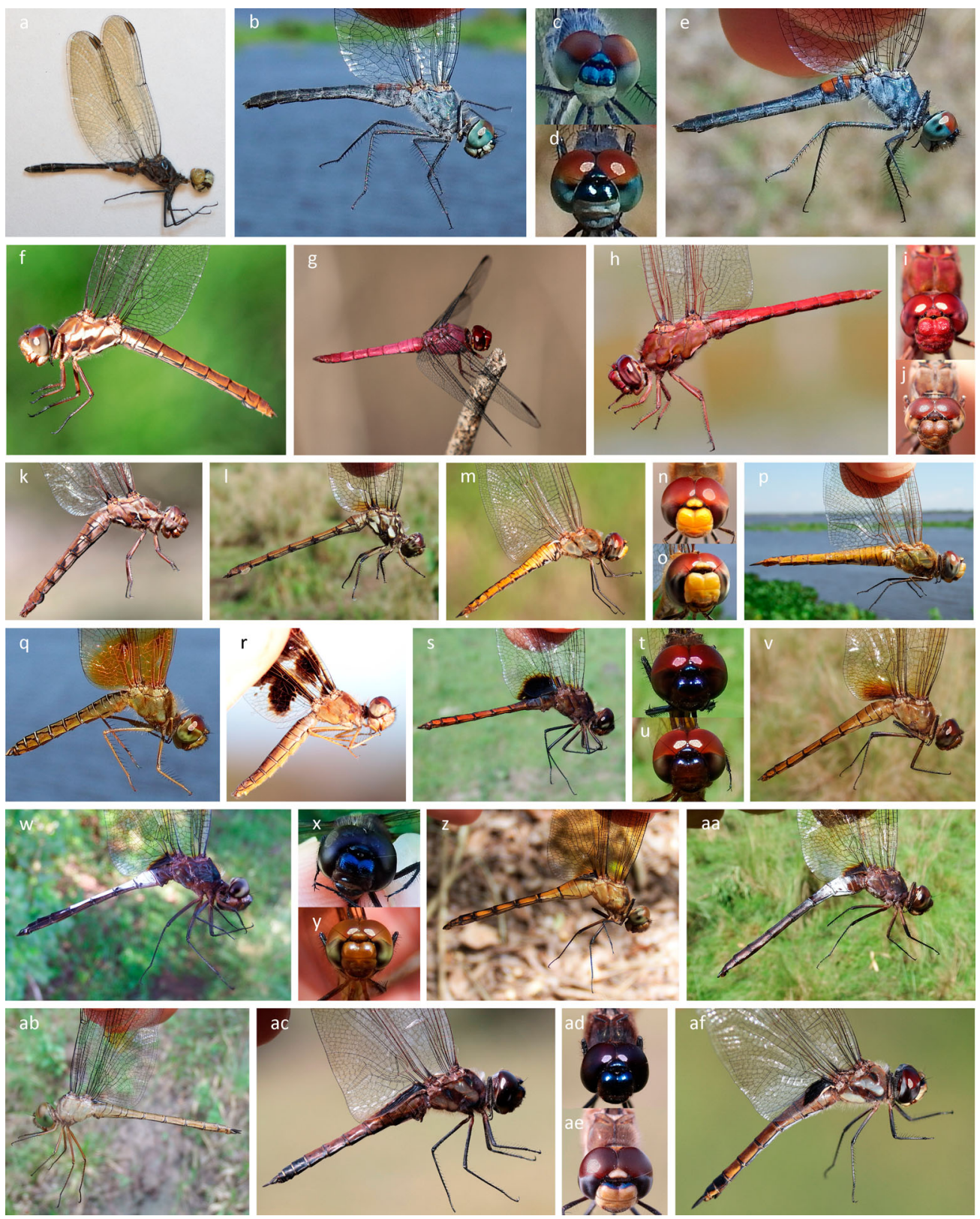

Figure 10. Libellulidae (Oligoclada - Tramea) of Neembucú: (a) Oligoclada pachystigma (male); (b, c) Oligoclada rubribasalis (male); (d, e) Oligoclada rubribasalis (female); (f) Orthemis aequilibris (female); (g) Orthemis discolor (male, San Pedro department); (h, i) Orthemis nodiplaga (male); (j, k) Orthemis nodiplaga (female); (1) Orthemis philipi (female); (m, n) Pantala flavescens (male); (o, p) Pantala flavescens (female); (q) Perithemis mooma (male); (r) Perithemis mooma (female); (s, t) Tauriphila argo (male); (u, v) Tauriphila argo (female); (w, $\mathrm{x}$ ) Tauriphila xiphea (male); (y, z) Tauriphila xiphea (female, gynomorphic); (aa) Tauriphila xiphea (female, andromorphic); (ab) Tholymis citrina (male); (ac, ad) Tramea cophysa (male); (ae, af) Tramea cophysa (female).

record. Previously only known from Argentine humid Chaco (Von Ellenrieder, 2010; Von Ellenrieder \& Garrison, 2008). Exclusive to Paraguay River, including in urban areas, not around lentic waterbodies as in Von Ellenrieder (2010) and Von Ellenrieder \& Garrison (2008). Generally perches around $0.5 \mathrm{~m}$ above water in patches of low to moderate riparian vegetation cover 
(including floating rafts of water hyacinth Eichhornia crassipes) up to $1 \mathrm{~m}$ tall. Prefers high temperatures. Present SSA, abundance peaks in summer.

Orthemis aequilibris Calvert, 1909 Figure 10f Rare

Adult male red (never purple). Female and immature brown with two pale longitudinal stripes on pterothorax. Wing veins reddish brown, costal vein black and membrane surrounding nodus hyaline (Von Ellenrieder, 2012). Male cerci and epiproct slender and almost equal in length in lateral view, female cerci less than twice as long as epiproct (Figure 19ae). TL: ca. 46. HW: 3842. Widely distributed Neotropical species. We recorded a single female flying over an emergent meadow (between 0.5-1.5 m tall) along the Paraguay River during autumn.

Orthemis discolor (Burmeister, 1839) Figure 10g Occasional

Adult male violet. Female and immature brown with two pale longitudinal stripes on pterothorax. Wing veins black and membrane surrounding nodus hyaline. Widespread in tropical South America. Although no individuals were collected, we observed several violet coloured Orthemis males that we tentatively identified as this species at large permanent wetlands, temporary grassy wetlands and flooded palm savannah, during autumn.

\section{Orthemis nodiplaga Karsch, 1891 Figure 10h-k Frequent}

Adult male bright red. Female and immature mostly brown with small light and black areas on pterothorax and pale middorsal stripe across thorax and anterior segments of $\mathrm{AB}$. $\mathrm{AB}$ short and thick, S4 width/length ratio of 0.59 or more. Costal vein reddish brown and small reddish brown spot surrounding nodus (Von Ellenrieder, 2012). TL: 43-49. HW: 35-40. Distributed across tropical south-eastern South America. In Ñeembucú, found mostly at large permanent wetlands and temporary grassy wetlands. Generally recorded close to water in areas with sparse, low growing vegetation, at mild to high temperatures. Present late summer and autumn.

\section{Orthemis philipi Von Ellenrieder, 2009 Figure 101 Rare}

Adult male with red $\mathrm{AB}$ and dark metallic purple frons and vertex, labial palp with medial black stripe as wide as $0.30-0.33$ of palp width. Female and immature mostly brown with large pale yellow spots on pterothorax. AB relatively long and slender, $\mathrm{S} 4$ width/length ratio less than 0.59 and constricted at S2-4. Wing veins black. Female cerci more than twice epiproct length (Figure 19af). Previously only known from the Dry Chaco in Argentina and Paraguay (Von Ellenrieder, 2009b, 2012), here recorded for the first time in the Humid Chaco. A single female collected whilst perched $3.5 \mathrm{~m}$ off the ground at gallery forest edge $(6 \mathrm{~m}$ tall), $13 \mathrm{~m}$ from large permanent wetland during autumn.

\section{Pantala flavescens (Fabricius, 1798) Figure 10m-p Common}

Yellow $\mathrm{AB}$ and face, $\mathrm{HW}$ base extremely widened without dark marking. Two lateral carinae present on S3-4 and strong transverse carina on S5 (Figure 17o). Three cells border on FW triangle in discoidal space (Figure 17n). HW: 38-41. AB: ca. 31. A globally-distributed trans-oceanic migrant (Troast, Suhling, Jinguji, Sahlén, \& Ware, 2016). Recorded in a variety of habitats with variable cover but low to moderate height $(0.3-1.5 \mathrm{~m})$, usually flying about $1.5-2 \mathrm{~m}$ above the substrate within $10 \mathrm{~m}$ of the water's edge at mild to high temperatures. Present summer and autumn.

\section{Perithemis mooma Kirby, 1889 Figure 10q, r Frequent}

Wings unmistakeable, orange (males) or marbled with dark brown (females). Triangle and subtriangle usually free (Figure 17a). Distinguished from other Perithemis species by hamule with spine recessed from tip and VL with V-shaped cleft and divergent lobes. TL: 23-28. HW: 1922 (Von Ellenrieder \& Muzón, 1999). Widespread in Neotropics. Strongly associated with the Paraguay River but also found at nearby grassy temporary wetlands. Usually perched around 
$0.7 \mathrm{~m}$ but up to $2 \mathrm{~m}$ above substrate at water's edge in low to moderately high riparian vegetation. Cool to relatively high temperatures. Present SSA.

Tauriphila argo (Hagen, 1869) Figure 10s-v Frequent

S4-10 red, rest of body dark brown to black and pruinose (male) or body mostly orange to yellowish-brown with thin black middorsal stripe from S4-7 (female and immature). Face red to reddish-brown, metallic violet postfrons and vertex in mature specimen. HW very broad at base with dark basal patches extending to anal angle and continuing along vein margins, or extensive amber wash in some females. HW: 34-39. AB: 25-32. Widespread in Neotropics. Recorded at large wetland types, absent from temporary pools, generally flying around 1-3 m above adjacent terrestrial habitat, especially forest/thicket edge, sometimes far from water's edge. Prefers high temperatures. Present SSA, abundance peaks in autumn.

\section{Tauriphila xiphea Ris, 1913 Figure 10w-aa Frequent}

Body colour mostly dark brown to black with light blue pruinescence on S3-6 (adult male) or S2-4 (adult female) or ochre-brown with black markings extending along distal margin of S3-10, middorsal carina and more diffuse on triangle on anterior edge of S6-7, and dark brown humeral stripes (immatures). Frons metallic blue (adult) or ochre-brown (immature). HW very broad at base with small brown basal spot bordered with yellow, not extending beyond end of membranule. Female - TL: ca. 46. HW: ca. 41. Distributed across south-eastern South America. Recorded at all large wetland types, absent from temporary pools, generally flying ca. 1-3 m above adjacent terrestrial habitat, especially forest/thicket edge, sometimes far from water's edge. Present SSA, most abundant spring and summer.

\section{Tholymis citrina Hagen, 1867 Figure 10ab Occasional}

Body colour light to dark brown. Wings with yellow spot around HW nodus and anal loop open posteriorly (Figure 18d). TL: 48-51. HW: 36-39. Widespread in Neotropics. Recorded exclusively near small wooded temporary wetlands in the Paraguay River ecosystem. Usually found patrolling low over ground (ca. $0.3 \mathrm{~m}$ ) in partially shaded clearings in dense thicket (canopy $1.6-3 \mathrm{~m}$ ), not far from water. Recorded during spring and summer.

\section{Tramea cophysa Hagen, 1867 Figure 10ac-af Common}

Body colour brown, thorax with two lateral oblique pale stripes, S9-10 mostly black. Postfrons metallic violet-blue (male) or pale yellow with posterior metallic violet-blue stripe (female) (Marmels \& Rácenis, 1982). HW very broad at base with dark brown to black basal spot reaching no further than vein MP. Medial, radial and apical planates with two cells, PS short. HW: 39-44. AB: ca. 31. Widespread in Neotropics. Recorded at all large wetland habitat types, absent from small temporary pools, becoming associated with large permanent wetlands during drier periods. Found flying or perched around $1 \mathrm{~m}$ above substrate, generally within $20 \mathrm{~m}$ from water's edge, over sunny areas with variable vegetation cover and low to moderate height. Tolerates mild to relatively high temperatures. Present year-round, peak abundance during autumn.

\section{ZYGOPTERA}

\section{CALOPTERYGIDAE}

\section{Hetaerina rosea Selys, 1853 Figure 11a, b Occasional}

Male FW with bright red basal spot, HW base dark reddish-brown with additional red spot at tip; thorax and base of $\mathrm{AB}$ coppery, $\mathrm{AB}$ black distally. Female body colour reddish-brown, wings amber, without red spots. Wings not petiolate, ca. 21 antenodal crossveins and mid-basal space subdivided by crossveins (Figure 20a). In male, length of median lobe and distal 1/3 of cerci approximately equal, paraprocts longer than $1 / 2$ of cerci. Female with well-developed occipital 

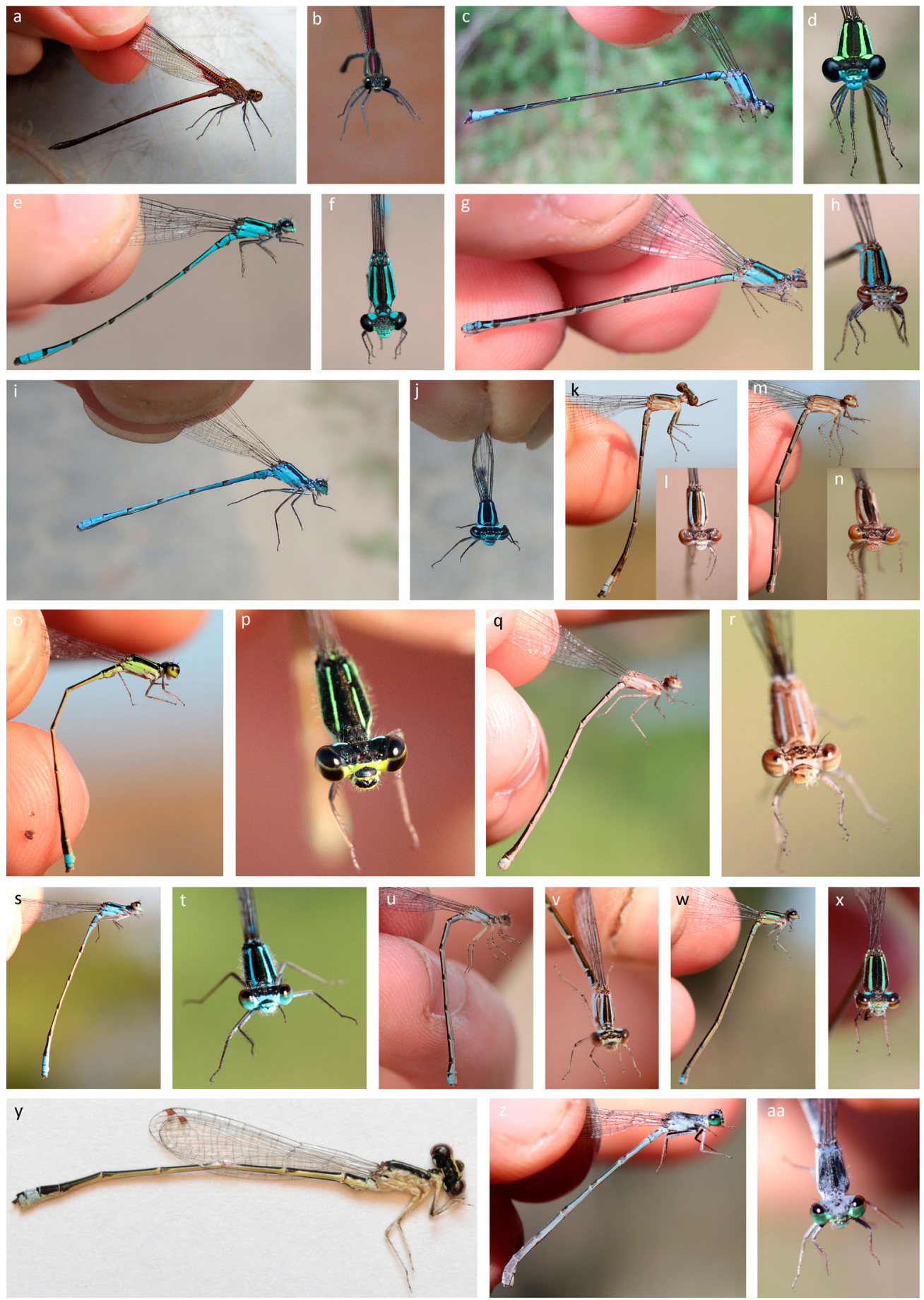

Figure 11. Calyopterygidae and Coenagrionidae (part 1, Acanthagrion - Homeoura) of Neembucú. (a, b) Hetaerina rosea (male); (c) Acanthagrion ascendens (male one); (d) Acanthagrion ascendens (male two); (e, f) Acanthagrion lancea (male); (g, h) Acanthagrion lancea (female); (i, j) Acanthagrion temporale (male); (k, l) Aeolagrion philipi (male); (m, n) Aeolagrion philipi (female); (o, p) Argentagrion ambiguum (male); (q, r) Argentagrion ambiguum (female); (s, t) Homeoura lindneri (male); (u, v) Homeoura lindneri (female one); (w, x) Homeoura lindneri (female two); (y) Homeoura nepos (male); (z, aa) Homeoura nepos (female). 
tubercles and posterior lobe of prothorax with angled sides. TL: 37-50. HW: 25-30. AB: 36-37 (male) and 31-32 (female). Widespread from Peru to northern Argentina. In Neembucú, recorded in wooded habitat bordering streams and in the Paraguay River ecosystem, including in urban settings. Recorded late winter and spring.

\section{COENAGRIONIDAE}

Acanthagrion ascendens Calvert, 1909 Figure 11c, d Occasional

Male body colour typically light blue to green and black, S1-7 black dorsally (sometimes almost entirely black), S8-9 entirely pale, S10 black with pale venter; thorax pale with black humeral and middorsal stripe and pale antehumeral stripes; head black posterior to frons with large pale postocular spots, blue anteriorly. Female colouration similar but tinged brown and dark areas less extensive, S8 similar to S1-7, S9 blue with black on basal half of lateral portion, S10 entirely blue. In male, S10 dorsally elevated, cerci long $(1.2-1.4 \mathrm{~mm})$, ventrally inclined and subapically constricted (Figure $21 \mathrm{k}$ ). Mesepisternal fossae separated from posterior end of sinus by more than twice their own length, their long axis parallel to middorsal carina; middorsal carina persistent between fossae and posterior end of interlaminal sinus (Figure 22f) (Leonard, 1977; Souza, Costa, \& Santos, 2010). Male - HW: 16-19. AB: 26-30. Locally distributed in tropics to the north and south of Amazonia (Leonard, 1977). In Neembucú, recorded exclusively at wooded temporary wetlands, including flooded palm savannah. Always found over water, usually at height of ca. $0.5 \mathrm{~m}$. Vegetation cover usually moderate to low with mixture of terrestrial (ca. 40\%) and aquatic (ca. 20\%) species but up to $5 \mathrm{~m}$ tall (i.e. Copernica alba palms), with ca. $60 \%$ shade and cool to mild temperatures. Only males recorded. Present SSA.

\section{Acanthagrion lancea Selys, 1876 Figure 11e-h Frequent}

Body colour similar to A. ascendens but, in male, blue lateral markings on S7 form elongated triangle; in female, S8 with joined dorsal and lateral black stripes and S9 with bilobate anterior black mark. In male, S10 not elevated, cerci slightly downwards inclined, rounded at tip in lateral view, constricted subbasally and subapically, paraproct sharply recurved at tip (Figure 211). Mesepisternal fossae adjoining mesepisternal sinus, rounded or elliptical in shape, their long axis transverse to middorsal carina. Posterolateral margins of sinus smoothly convex, interlaminal sinus entire (Figure 22d) (Leonard, 1977; Souza et al., 2010). HW: 15-18. AB: 23-26. Disjunct distribution in SE Brazil-Paraguay-Argentina, and Peru-Ecuador. Recorded in a variety of habitats, generally above or close to water, at $0.2 \mathrm{~m}$ height, in areas with variable terrestrial vegetation cover and height and variable aquatic vegetation cover but low height, low shade and at mild temperatures. Present year-round, peak abundance in autumn, scarce during spring and summer.

\section{*Acanthagrion temporale Selys, 1876 Figure 11i-j Rare}

Adult male with more extensive pale (light blue to green) colouration than other Acanthagrion species; S3-7 with narrow black dorsal stripes, expanded posteriorly, S8-9 entirely pale; head mostly black, posterior of frons with two pale ovoid postocular spots connected by a bar, anterior to frons mostly blue but postclypeus black. Female colouration similar. In male, S10 not elevated, cerci constricted subapically, in lateral view. In female, mesostigmal laminae diagonally traversed by a strong fold; subtriangular area between this and admesal borders of lamina subplanate; mesepisternal fossae separated on midline, elliptical in shape with pointed end directed laterally, margin at this point indistinct, merging with mesepisternal surface (Figure 22e) (Leonard, 1977). HW: 13-16. AB: 20-23. New country record. Inhabits open tropical habitats to the north and south of Amazonia. Recorded once in short open grassland around $90 \mathrm{~m}$ from water at ca. $10 \mathrm{~cm}$ above ground in the Ñeembucú Wetlands during summer. 
*Aeolagrion philipi Tennessen, 2009 Figure 11k-n Rare

Body colour mostly tan brown, black dorsally with two pale blue antehumeral stripes on thorax. Rear of head usually pale above occipital foramen, sometimes with oblong postocular spots, and a narrow lateral black bar along edge of compound eyes. In male, S8-9, venter of S10, postclypeus, gena and labrum pale blue, top of head variably brown to black. Male cerci, in lateral view, ca. 1.5 times longer than S10, wider at apex than base (apical width about 2/3 of cerci length) (Figure 21c). Female mesanapleural suture with marked dorsal convexity and black spot below (Figure 22a). Male - HW: 14-16. AB: 22-25. Female - HW: 15-17. AB: 21-25 (Tennessen, 2009). New country record. Chaco endemic distributed from S Bolivia to N Argentina. Only recorded in gallery forest interior (with extensive bromeliad undergrowth) in the Neembucú Wetlands during winter.

\section{Argentagrion ambiguum (Ris, 1904) Figure 11o-r Common}

Male and andromorphic female body colour light blue or green and black; S1-8 dorsally black, S9-10 mostly pale; thorax laterally pale, dorsally black with pale antehumeral stripes; head dorsally black with elongated postocular spots, anteriorly mostly pale but labrum and postclypeus distinctly black. Heteromorphic female mostly pale brown; AB black dorsally, S9-10 mostly pale blue; thorax with thin pale blue to green antehumeral stripes; head (including labrum and entire back of head) brown. In both sexes, posterior lobe of prothorax widely bilobate (Figures 21s, 22i) and PS rhomboidal with costal side the longest (Figure 21v) (Von Ellenrieder, 2008). Male cerci, in dorsal view, about twice as long as wide, margin of S10 entire (Figure 21o); in lateral view, dorsal branch of paraprocts rounded (Figure 21p). In female, lateral margins of mesostigmal plates bluntly pointed. HW: 13-18. AB: 18-22. Distributed across south-eastern South America as far north as SE Bolivia. Recorded in a variety of more open habitats, absent from wooded temporary wetlands. Usually found close to water, in grassy vegetation with high cover and low height and low aquatic vegetation cover, around $20 \mathrm{~cm}$ above substrate, at cool to hot temperatures. Present year-round, abundance peaks during autumn and winter.

\section{Homeoura lindneri Ris, 1928 Figure 11s-x Common}

Male and andromorphic female black with pale blue to yellow and black; S1-7 black dorsally, S8-9 entirely pale, S10 pale with black posterior margin; thorax pale laterally, dorsally black with pale antehumeral stripes; head dorsally black with large oval pale postocular spots, postocular bar present, sometimes fused to spots. Heteromorphic female similar to male but dark colouration includes brown, especially along humeral stripes, S9 with dark dorsal marking, and entire back of head pale. PS rhomboidal (Figure 21w). In male, posterior margin of S10 with U-shaped cleft and two apical tubercles (Figure 21q), cerci about as long as or shorter than S10, in lateral view, dorsal and ventral margins diverging apically and dorsal margin longer than ventral, such that apex is wider than base, apex obliquely truncated dorsoventrally (Figure 21r); medial projection of posterior lobe of prothorax approximately rhomboidal (Figure 21t). In female, medial projection of posterior lobe of prothorax triangular to rectangular, and lateral margins of mesostigmal plates bluntly pointed (Figure 22j). FW: ca. 14. AB: 20-21 (Von Ellenrieder, 2008). Disjunct distribution in La Plata basin and Peruvian Amazon. Recorded in all habitats but with a preference for the margin of the Paraguay River. Usually found over drier areas than most other species (besides $T$. willinki) but still mostly within $10 \mathrm{~m}$ of water, vegetation cover relatively high and mean height low, but with some taller trees, aquatic vegetation variable. Perches ca. $20 \mathrm{~cm}$ above substrate. Tolerates cool to hot temperatures. Present year-round, less prevalent during summer.

\section{Homeoura nepos (Selys, 1876) Figure 11y-aa Frequent}

Male body colour pale blue to yellow and black; S1-8 and S10 black dorsally, S9 mostly pale with black anterior margin; thorax laterally pale, dorsally black with pale antehumeral stripes; 

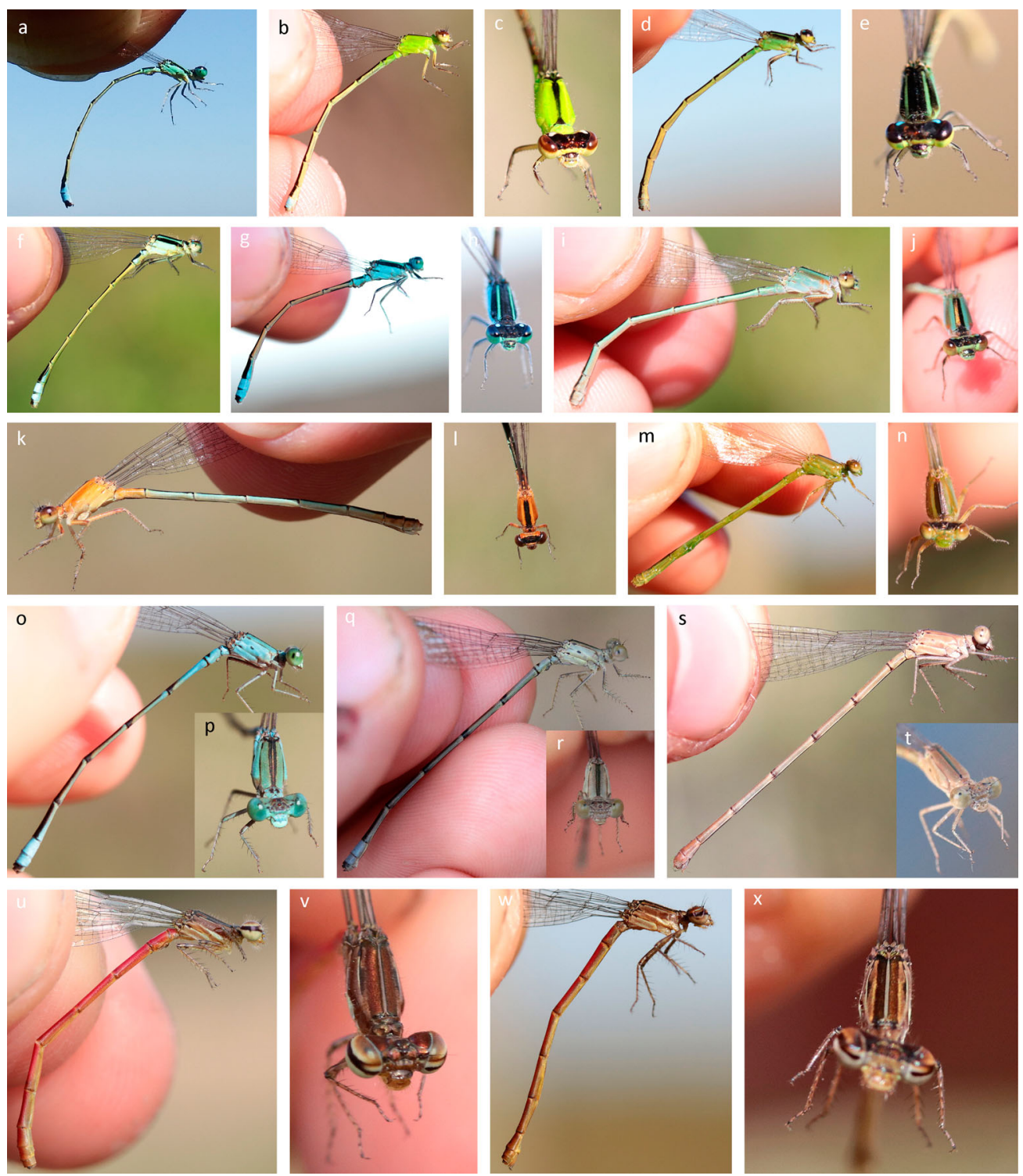

Figure 12. Coenagrionidae (part 2, Ischnura - Telebasis) of Neembucú. (a) Ischnura capreolus (male one); (b, c) Ischnura capreolus (female one); (d, e) Ischnura capreolus (female); (f) Ischnura fluviatilis (male one); (g, h) Ischnura fluviatilis (male two); (i, j) Ischnura fluviatilis (female, blue morph); (k, l) Ischnura fluviatilis (female two, orange and blue morph); (m, n) Ischnura fluviatilis (female three, immature); (o, p) Telebasis obsoleta (male one); (q, r) Telebasis obsoleta (male two); (s, t) Telebasis obsoleta (female); (u, v) Telebasis willinki (male); (w, x) Telebasis willinki (female).

head dorsally black with large pale postocular spots, sometimes with a concave anterior margin, and postocular bar present. Female colouration generally browner; dorsally black from S1-9, S10 mostly to entirely pale, heteromorphic female with entire back of head pale. In both sexes, medial projection of posterior lobe of prothorax approximately rectangular (Figures 21u, 22k) and PS quadrangular (Figure 21x). In female, lateral margins of mesostigmal plates bluntly rounded, anterior and posterior margins approximately parallel sided (Figure 22k). Male - HW: ca. 13. AB: 16-19. Female - AB: 17-20. Neembucú represents the southernmost extent of this tropical South American species. Found in a variety of habitats, but less common in wooded wetlands. 
Usually close to water, ca. $20 \mathrm{~cm}$ above substrate, in areas with variable low terrestrial vegetation cover and moderate aquatic vegetation cover (ca. 30\%) of moderate to tall height $(0.2-0.6 \mathrm{~m})$. Mild to warm temperatures. Present year-round.

Ischnura capreolus (Hagen, 1861) Figure 12a-e Frequent

Very small. Body colour mostly light blue or green with black; AB black dorsally from S1 to basal half of S9, S9 entirely pale blue, S10 black dorsally; head dorsally black with small rounded pale postocular spots, pale anteriorly, except for black postclypeus. Thorax of male and andromorphic female dorsally black with pale antehumeral stripes but distinctly bright lime green thorax with black middorsal stripe in heteromorphic female (Figure 12b, c). In male, posterior margin of S10 raised and deeply forked, cerci entire and paraprocts forked and at least as long as S10 (Figure 21n). In female, posterior lobe of prothorax with a medial cleft and mesostigmal plates separated (Figure 22 g). HW: 8-16. AB: 16-20. Widespread in Neotropics. More prevalent in the Neembucú Wetlands than the Paraguay River ecosystem and found in all lentic wetland types. Usually found just above water $(<20 \mathrm{~cm})$ in areas with high water cover (ca. 70\%), moderate to high terrestrial vegetation cover with low mean height and substantial (ca. 25\%) low-growing aquatic vegetation (ca. $0.2 \mathrm{~m}$ tall). Low to high temperatures. Present year-round, peak abundance in winter.

\section{Ischnura fluviatilis Selys, 1876 Figure 12f-n Abundant}

Male and andromorphic female body colour pale blue to green and black; S1-7 and S10 dorsally black, S8-9 pale blue with black along dorsoanterior edge; thorax dorsally black with pale antehumeral stripes; head dorsally black with small rounded pale postocular spots, anteriorly pale with black postclypeus. Body colour of heteromorphic females highly variable with blue, green, brown and/or orange and black, individuals with an orange thorax distinct in region; $\mathrm{AB}$ segments black dorsally; postocular spots sometimes fused into wide postocular bar. In male, posterior edge of S10 entire, not raised; cerci bifid with subequal branches; paraprocts entire, curving dorsally with a pointed tip directed distally, shorter than S10 (Figure $21 \mathrm{~m}$ ). In female, posterior lobe of prothorax bilobate, mesostigmal plates confluent, forming a single rhomboidal structure (Figure 22 h) (Lencioni, 2006; Realpe, 2010). TL: 28-36. HW: 14-18. Widespread in South America. Recorded in all habitats but prefers open areas, especially grassy temporary wetlands, emergent meadows and large permanent wetlands, scarce in wooded wetlands. Usually close to water, ca. $20 \mathrm{~cm}$ above substrate, in areas with moderate to high low-growing terrestrial vegetation cover, variable (generally lower) aquatic vegetation cover. Tolerates low to high temperatures. Present year-round, less abundant during summer.

\section{Telebasis obsoleta (Selys, 1876) Figure 12o-t Common (SSA), Occasional (winter)}

Both sexes lack humeral stripes and have distinctly pale eyes. Body colour almost entirely light blue or olive green in males and light brown in females, black restricted to middorsal thoracic stripe and on dorsum and posterior margins of S2-7 (reduced to submarginal posterodorsal patches in some females) and S10 in male. Male cerci in dorsal view, approximate with distance between them less than 0.2 their basal width (Figure 21d, e), in lateral view, a strongly elevated dorsally directed medial ridge is clearly visible, posterodistal margin acuminate (Figure 21d, e). Female middorsal carina well developed along anterior portion, separating a pair of large mesepisternal pits (ca. twice as long as wide) and posterior lobe of pterothorax broadly bluntly angulate laterally (Figure 22b) (Garrison, 2009). HW: ca. 17. AB: 27-28. Widespread in humid tropical South America. Associated with large permanent wetlands and wooded temporary wetlands in the Neembucú Wetlands, but also in flooded grassland and the Paraguay Rive ecosystem, including wooded suburban areas. Usually in areas with moderately low terrestrial veg cover (ca. 
45\%), but tall canopy (ca. 3-5 m) and partial shade (ca. 50\%), ca. $15 \mathrm{~cm}$ above substrate. Low to high temperatures. Present year-round.

\section{Telebasis willinki Fraser, 1948 Figure 12u-x Common}

Very small, mostly red coloured damselfly with bronzy pterothorax. Male cerci in dorsal view, divergent and distance between bases of cerci more than half of basal width of each cercus, in lateral view, subequal in length to paraprocts and distal half straight (Figure 21f, g). Female mesepisternal sinus modified into a 'cup-like' formation with posterior margin of mesostigmal plate strongly raised (Figure 22c) (Garrison, 2009). TL: 23-29. HW: 12-14. Widespread in humid tropical South America. Associated with large permanent wetlands and wooded temporary woodlands in the Neembucú Wetlands, but also in forest and along the Paraguay River, uncommon in grassy wetlands unlike in the Argentine Yungas (Von Ellenrieder \& Garrison, 2007). Usually ca. $0.5 \mathrm{~m}$ above substrate, generally close to water (but far in forest interior) in areas with high terrestrial vegetation cover, relatively low mean height and moderate to high maximum height, variable shade. Prefers mild to high temperatures. Present year-round, peak abundance in winter.
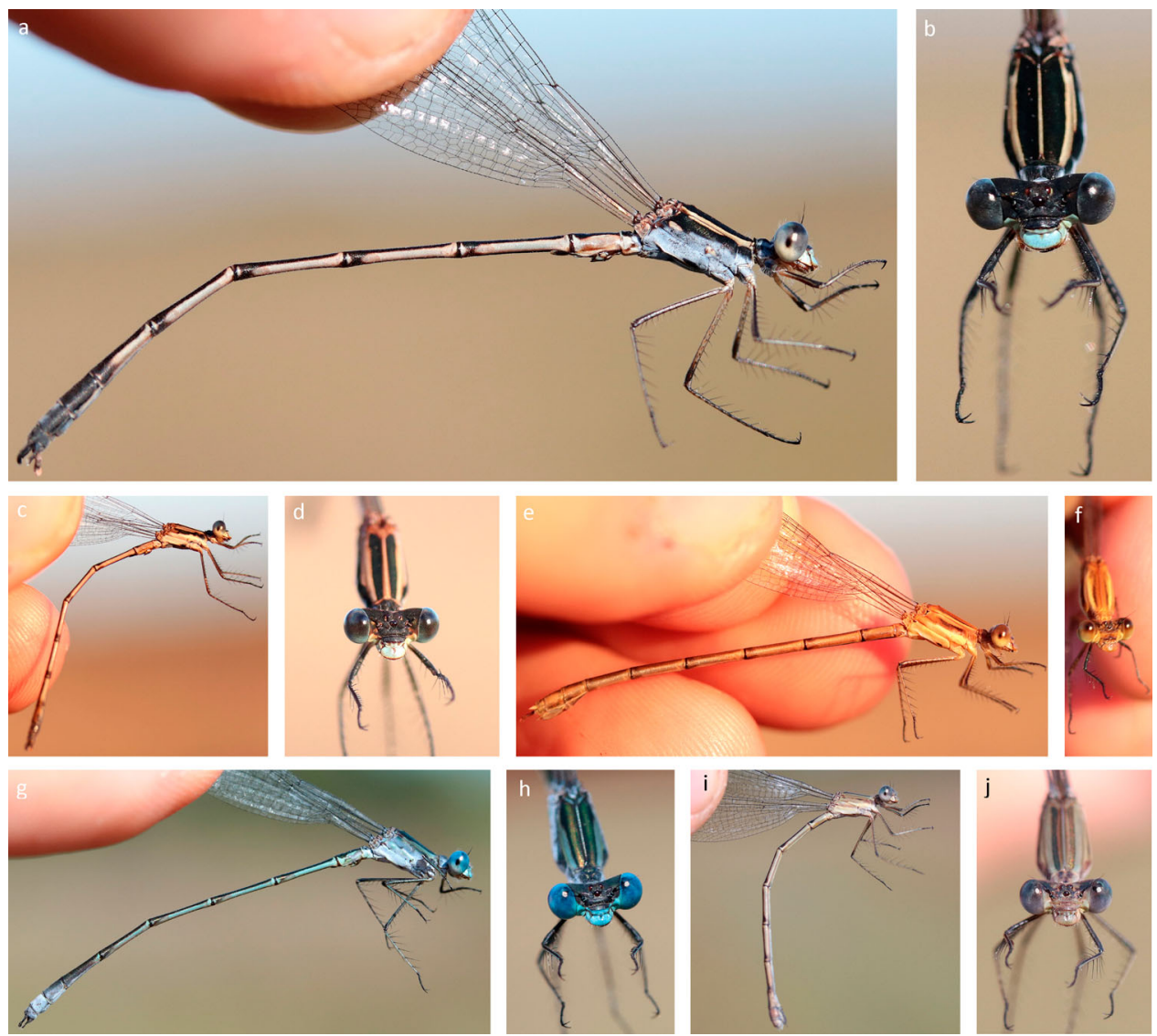

Figure 13. Lestidae of Neembucú: (a, b) Lestes minutus (mature male); (c, d) Lestes minutus (immature male); (e, f) Lestes minutus (female); (g, h) Lestes spatula (male); (I, j) Lestes spatula (female). 


\section{LESTIDAE}

\section{*Lestes minutus Selys, 1862 Figure 13a-f Occasional}

Adult male AB mostly black with pale blue to tan lateral markings on S1-7, thorax dorsally black with pale middorsal and humeral stripes, laterally blue and pruinose, black along dorsal margin of mesepimeron, head and eyes mostly black with labrum, anterior margin of anteclypeus and gena pale. Female and immature mostly light brown, entire face and eyes light grey to blue. In both sexes, venter of thorax with three large dark marks and one small brown spot on each side (Figure 20d). Male cerci bear two strong teeth on inner surface, one at base and the other proximal to apex with a row of teeth located between them (Figure 20f). Male - HW: 16-19. AB: 26-30. Female - HW: 18-20. AB: 25-28. New country record, representing a $1000 \mathrm{~km}$ southward range expansion from previous limit in Mato Grosso. Widespread in temporary grassland wetlands in South America. Recorded at grassy temporary wetlands and large permanent wetlands. Usually in areas with high water cover (ca. 80\%), and variable short (grassy) vegetation cover, ca. $10 \mathrm{~cm}$ above substrate. Low to high temperatures. Present autumn, winter and spring, peak abundance during winter.

\section{Lestes spatula Fraser, 1946 Figure 13g-j Rare}

Adult male S1-6 dorsally metallic black, laterally pale blue, S9-10 mostly pruinose pale grey, S7-8 transitional, thorax dorsally pale blue with metallic postdorsal stripes, head dorsally black, anteriorly pale blue, eyes vivid blue. Female and immature body colouration similarly patterned to male but pale areas greenish to bluish brown, S7-10 similarly patterned to anterior segments, mesepimeron with thin metallic longitudinal stripe, eyes blue to grey. In both sexes, venter of thorax with two tiny black dots on anterior portion and two diffuse brown stripes (Figure 20e). In lateral view, cerci appear straight and have only a basal tooth on inner margin, narrowed along distal $1 / 4$ and about as long as paraprocts (Figure $20 \mathrm{~g}$ ), paraprocts with basal carina on internal margin. Female subgenital plate pointed posteriorly. HW: 19-24. AB: 27-31. Pampas biome endemic. Recorded exclusively in grassy temporary wetlands of the Paraguay River ecosystem in areas with high terrestrial vegetation cover (ca. 90\%), low height $(0.3-0.6 \mathrm{~m})$ and no aquatic vegetation, ca. $10 \mathrm{~cm}$ above substrate. Tolerates low to high temperatures. Present in autumn and winter.

\section{KEY TO THE ANISOPTERA OF ÑEEMBUCÚ}

1 Eyes on top of head separated by space equal to distance between lateral ocelli (Figure 14a).... Gomphidae (8)

1' Eyes on top of head touching (Figure 14b, c) (except Diastatops intensa [10]) ............ 2

2 FW triangle longitudinally elongated. HW triangle at about same distance from arculus as FW triangle (Figure 14d). Eyes meeting for a considerable distance, forming an eye seam (Figure 14b). Aeshnidae (3)

2' FW triangle transversely elongated. HW triangle closer to arculus than FW triangle (Figure 14e). Eyes meeting at single point or separated by a space shorter than distance between lateral ocelli. (Figure 14c) Libellulidae (10)

\section{Aeshnidae}

3 Body colour plain brown (Figure 51), wings brown-tinged to first antenodal crossvein or slightly beyond. Proximal cell of each discoidal triangle crossed; anal triangle two celled. (Figure 15a). In female, sternum of S10 with a sclerotised posterior process bearing two long apical spines (Figure 15b) 
a)

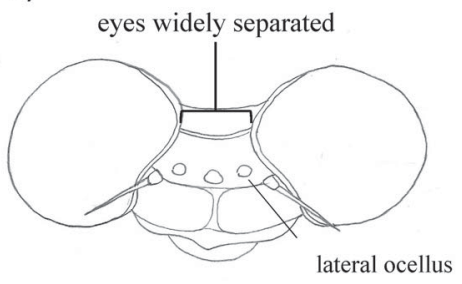

Phyllocycla argentina b)

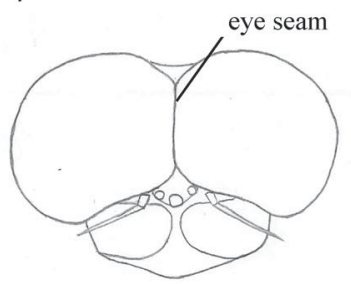

Coryphaeschna perrensi c)

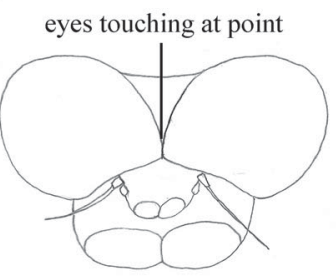

Erythemis vesiculosa d)

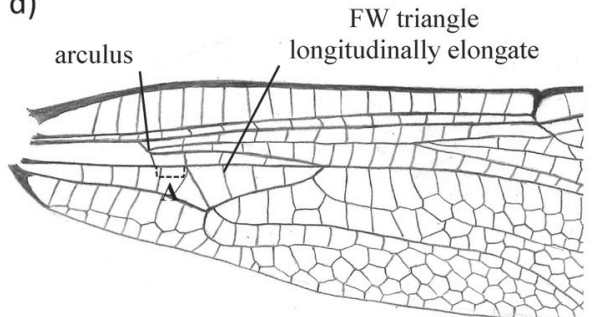

A $=$ B

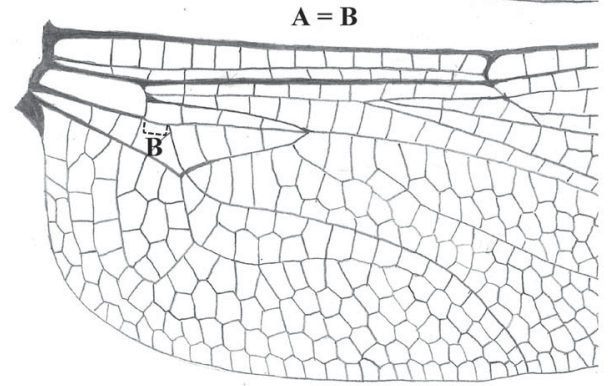

Coryphaeschna perrensi e)
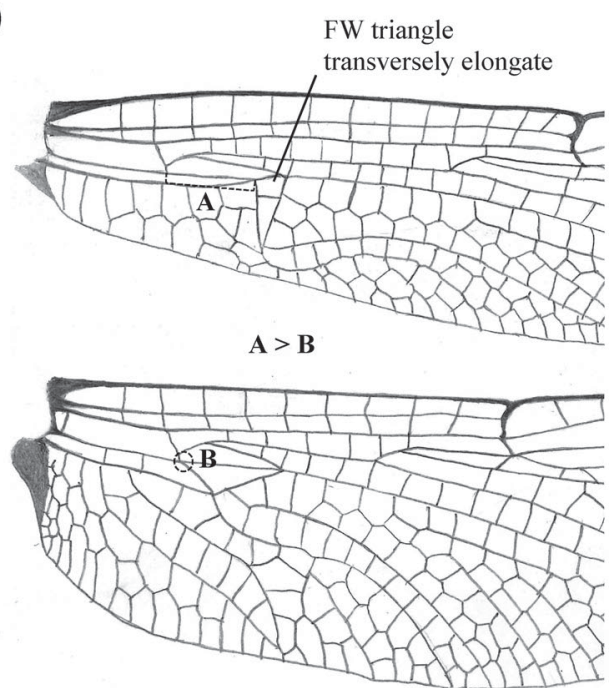

Erythemis credula

Figure 14. Key diagnostic features between Anisoptera families in Neembucú: dorsal view of head showing (a) eyes widely separated by distance equal to distance between lateral ocelli in the Gomphidae, (b) eyes touching over a considerable distance to form an eye seam in the Aeshnidae, and (c) eyes touching at a point or separated by space shorter than between the lateral ocelli in the Libellulidae; wing bases showing (d) FW triangle longitudinally elongated and distances between FW and HW triangles and arculus approximately equal in Aeshnidae and (e) FW triangle transversely elongated and HW triangle closer to arculus than FW triangle in the Libellulidae.

3' Body colour includes red, green, blue and/or black (not plain brown); wings not brown tinged to first antenodal or slightly beyond. Proximal cell of each discoidal triangle not crossed (Figure 15c) .........................................................

4 Thorax, in lateral view, with two thin blue or green diagonal stripes (Figure $5 \mathrm{~m}$, o). Sternum of S1 with a conical tubercle in males (Figure 15e) Rhionaeschna bonariensis

4' Thorax, in lateral view, lacks two thin diagonal stripes (Figure 5a, b, d, f, h, j). Sternum of S1 lacks conical tubercle (Figure 15f)

5 Vein $\mathrm{RP}_{2}$ with a marked convex bend at distal end of PS, upper sector of arculus shorter than lower sector (Figure 15g). (Figure 5a) Anax amazili

5' Vein $\mathrm{RP}_{2}$ curves evenly at distal end of PS, upper sector of arculus as long as or longer than lower sector (Figure 15h)

6 Face entirely or mostly orange, red or reddish-brown, wing veins reddish-brown

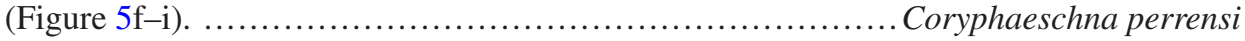

6' Face mostly green or blue (never red) (Figure 5c, k), wing veins black (Figure 5b, j) ....7 


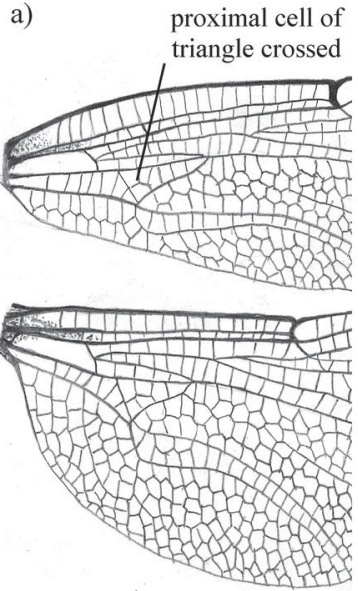

Gynacantha convergens

e)

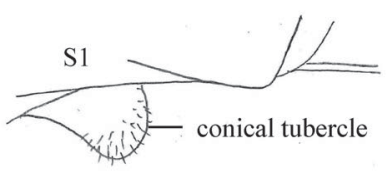

Rhionaeschna bonariensis

f)

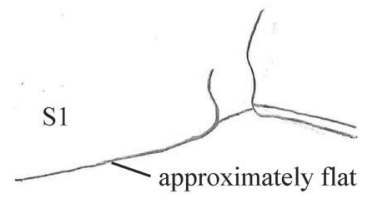

Coryphaeschna perrensi

i)

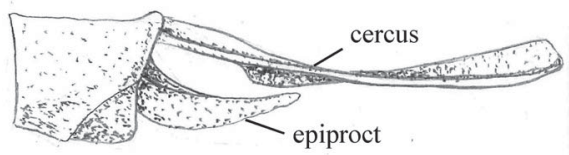

Coryphaeschna adnexa

b)

g)

h) proximal cell of
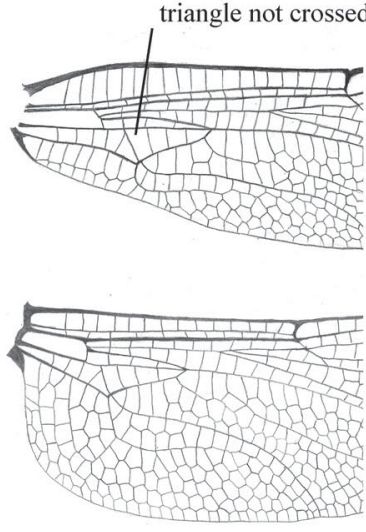

Coryphaeschna perrensi

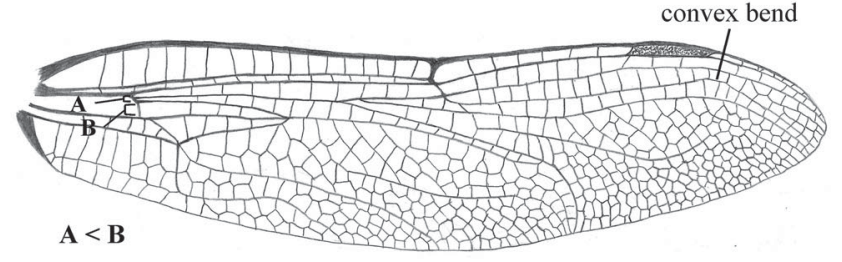

Anax amazili

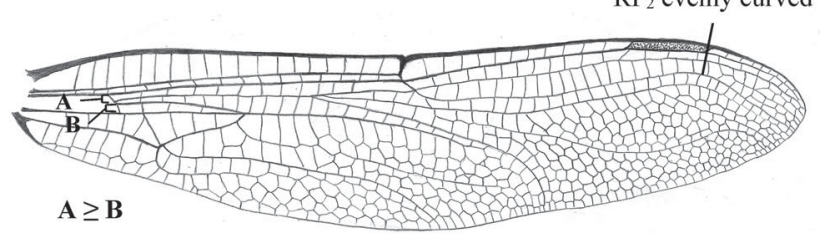

Coryphaeschna perrensi

j)

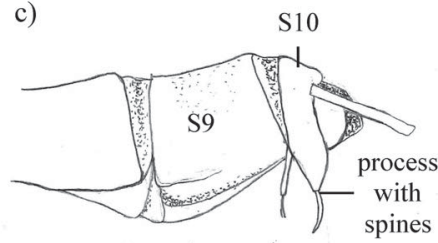

Gynacantha convergens

d)

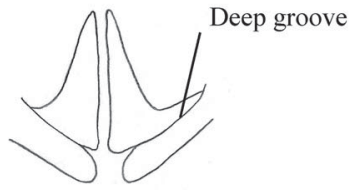

Gynacantha convergens

$\mathrm{RP}_{2}$ with marked convex bend

\section{.}


a)

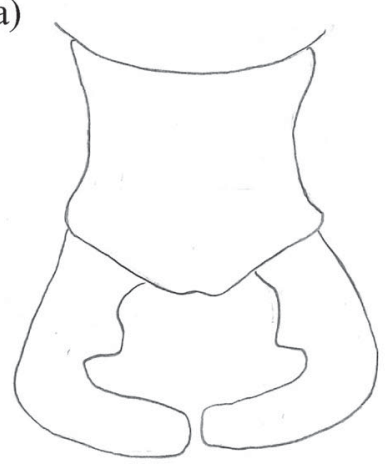

b)

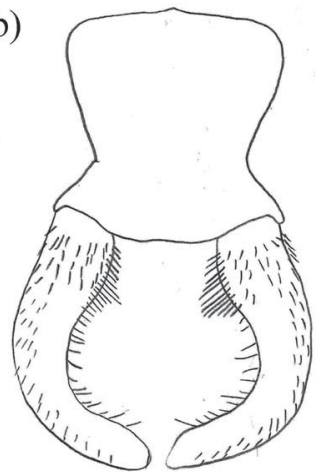

c)

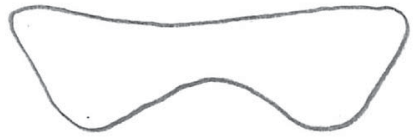

d)

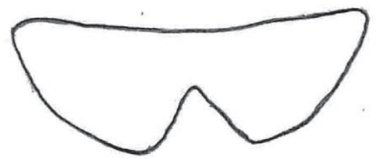

Figure 16. Key diagnostic features of Aphylla species in Neembucú: dorsal view of male cerci in (a) Aphylla distinguenda and (b) Aphylla theodorina; and VL shape in (c) Aphylla distinguenda and (d) Aphylla theodorina. [Drawings (b) and (c) adapted by permission from Springer Nature: Section 3, Part 2: Anisoptera, Figure 3.2.682. In: Encyclopedia of South American Aquatic Insects: Odonata - Anisoptera by Charles W. Heckman @ 2006 Springer, https://doi.org/10.1007/978-1-4020-4802-5_3].

7 Face usually contains blue. Lacks dark spot on mesepisternum (Figure 5c, e). Male epiproct reaches to ca. $40 \%$ of cerci length (Figure 15f) .......... Coryphaeschna adnexa

7' Face bright green, never contains blue, dark spots on mesepisternum (Figure 5k), the outer margin convex in females. Male epiproct reaches to ca. $60 \%$ of cerci length (Figure 15i) Coryphaeschna viriditas

\section{Gomphidae}

8 Face entirely dull yellow (Figure 6f), body colour dull olive yellow and brown, lacks reddish-brown and male with flanges on S8 (Figure 6e) ........... Phyllocycla argentina

8' Face with light and dark colouration (Figure 6b, d), body colour includes reddish-brown (Figure 6a, c) and male without flanges on S8 (Figure 6a) ........................ 9

9 Costal vein entirely yellow. Dorsal thorax with two pairs of pale stripes and pale on middorsal ridge, posterior and anterior margins. Anterior portion of postclypeus mostly pale (Figure 6d). Male cerci lack tooth but with fringe of long black hairs along inner margin (Figure 16b). VL with V-shaped excision for $1 / 2$ to $3 / 5$ its length, angle between lobes 60-90 and lobes broadly rounded (Figure 16d) .Aphylla theodorina

9' Costal vein black or brown with pale frontal margin. In dorsal view, thorax with single pair of bold pale stripe adjacent to middorsal carina and posterior margin. Anterior portion of postclypeus mostly dark brown (Figure 6b). Male cerci bear a strong tooth on inner surface (Figure 16a). VL with V-shaped excision extending half of its length, base of excision rounded, angle between lobes $90^{\circ}$ and lateral lobes broadly rounded (Figure 16c) Aphylla distinguenda

\section{Libellulidae}

10 Eyes separated (Figure 14a). Wings appear wrinkled, heavily darkened and iridescent (Figure 7c,d).

10' Eyes in contact (Figure 14c). Wings do not appear wrinkled, heavily darkened and iridescent.

11 Costal side of FW triangle almost as long as proximal side. Discoidal field of FW narrowed distally (Figure 17a). Wings orange (Figure 10q) or marbled with dark brown (Figure 10r), HW $<22 \mathrm{~mm}$ 
a) $\quad$ A $\approx$ B

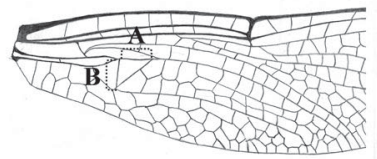

Perithemis mooma b)

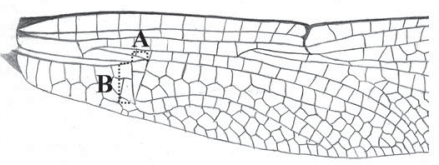

Erythemis credula c)

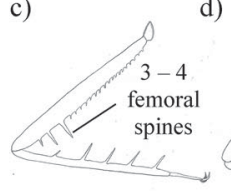

Erythemis peruviana

d)

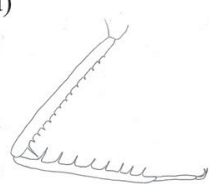

Erythrodiplax nigricans e)

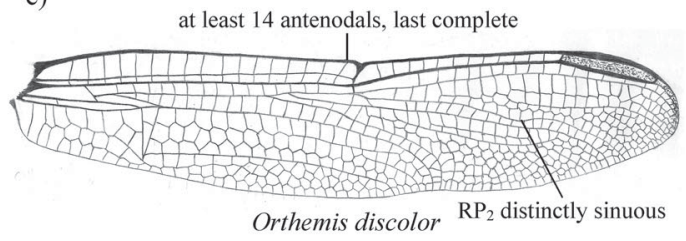

f) sectors of arculus 1) separated

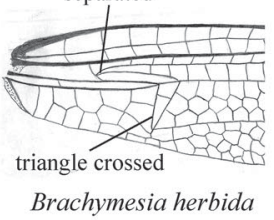

g) sectors of arculus

g) stalked

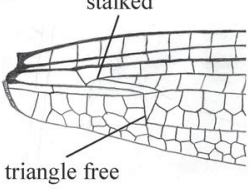

triangle free h) one discoidal cell row

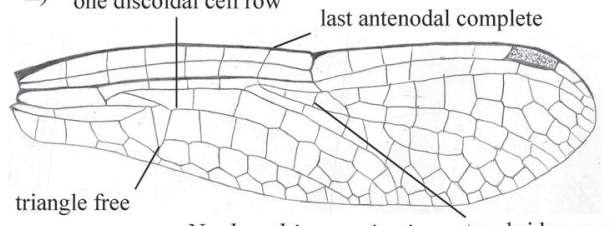

Nephepeltia aequisetis

i)

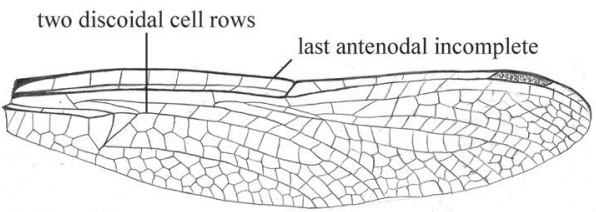

Idiataphe longipes

k) four discoidal cell rows

j) three discoidal cell rows

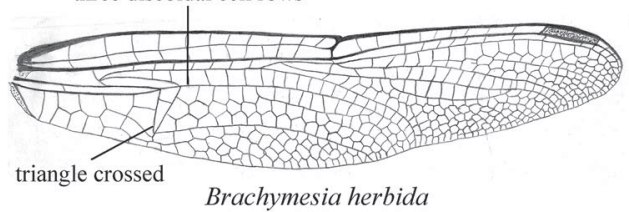

1)

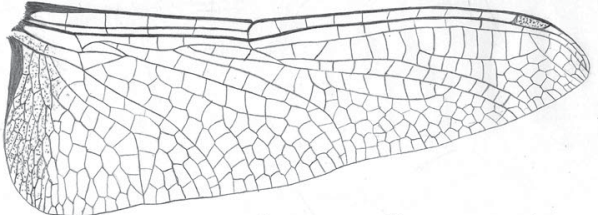

HW base broadened

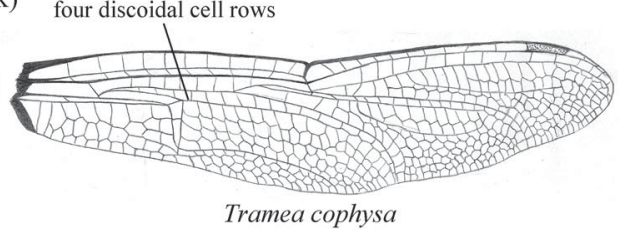

m)

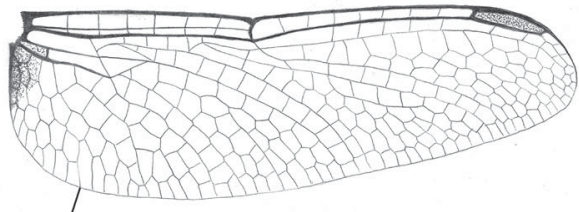

Erythrodiplax paraguayensis n)

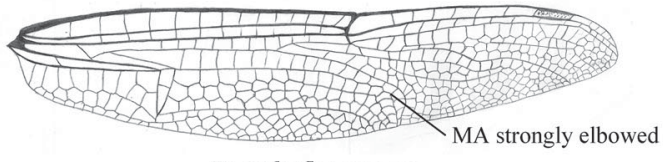

Pantala flavenscens o)

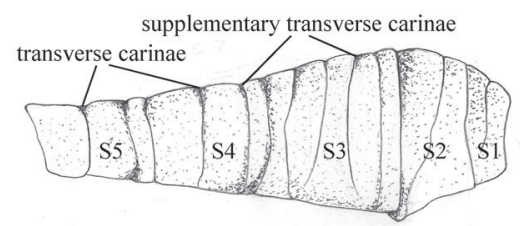

Pantala flavenscens

Figure 17. Key diagnostic features between species of Libellulidae in Neembucú, part one: FW triangle costal and proximal sides (a) almost equal in length in Perithemis, versus (b) costal side shorter than proximal side; hind femur with (c) three to four strong distal spines on hind femur in Erythemis, versus (d) lacking three to four strong spines; (e) wing with at least 14 antenodal crossveins, last antenodal complete and $\mathrm{RP}_{2}$ sinuous in Orthemis; sectors of arculus (f) separated or (g) stalked; (h) one cell bordering triangle in discoidal space, triangle free, (i) two cells bordering triangle in discoidal space, triangle free, (j) three cells bordering triangle in discoidal space, triangle crossed, (k) four cells bordering triangle in discoidal space, triangle crossed; (1) HW broadened at base, versus (m) HW not broadened at base; (g) MA strongly elbowed at distal end of median planate in, and (h) S3-4 with supplementary carina and S5 with strong transverse carina in Pantala flavescens. 
11' Costal side of FW triangle shorter than proximal side (Figure 17b). Wings not orange or

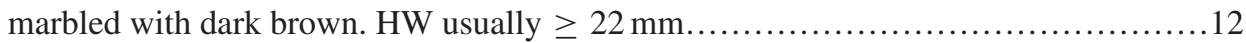

12 Hind femur with three to four distinct long and strong spines on its distal half (sometimes broken!), numerous short and distally directed spines on its basal half (Figure 17c). S1-3 widened in lateral view, FW with at least $11 \frac{1}{2} 2$ antenodal crossveins, discoidal area parallelsided with three discoidal cells bordering triangle (Figure 14e), and PS large40(Erythemis)

12' Hind femur lacks three to four long and strong spines on its distal half (Figure 17d) ... 13

$13 \mathrm{FW}$ with at least 14 antenodal crossveins, last one complete, $\mathrm{RP}_{2}$ distinctly sinuous (Figure 17e). S8 of female with lateral flanges (Figure 10f, k, 1)...........37 (Orthemis)

13' FW usually with fewer than 14 antenodal crossveins, last one incomplete or complete,

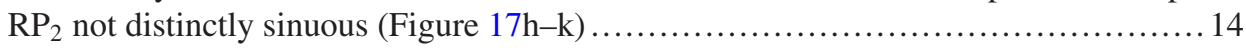

14 Sectors of arculus in FW separated (Figure 17f) ............................... 15

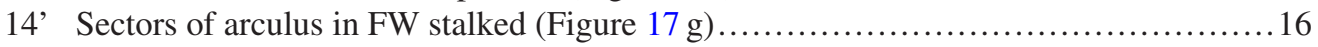

15 FW triangle and subtriangle free and two cells border on discoidal space of FW (Figure 17i). Legs long (Figure 8s, t)...........................Idiataphe longipes

15 FW triangle and subtriangle crossed and three cells border on triangle in discoidal space of FW (Figure 17j). Legs not long (Figure 7a, b) .................. Brachymesia herbida

16 HW broadened at base (Figure 171) .......................................... 17

16' HW not broadened at base (Figure $17 \mathrm{~m}$ ) .................................... 23

17 HW lacks dark basal spot (Figure $10 \mathrm{~m}, \mathrm{p}$ ). MA strongly elbowed at distal end of median planate (Figure 17n). S3-4 with supplementary transverse carina and S5 with strong transverse carina (Figure 17o)............................................. flavescens

17 HW possesses dark basal spot (Figures 7e, h, 8z-ae, 10s-aa, ac, af). MA not strongly elbowed at distal end of median planate. S3-4 lack supplementary transverse carina and

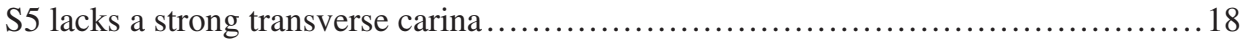

18 HW basal spot reaches distal end of triangle (Figure 7e, h) and FW with two bridge crossveins (Figure $18 \mathrm{~g}, \mathrm{~h}$ ) ..................................... Edonis helena

18 Basal spot does not reach distal end of triangle, or, if it does, then only one bridge crossvein

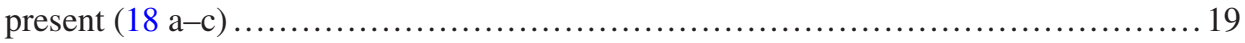

19 Discoidal space of FW consists of four rows of cells and medial planate with two cells in FW (Figure 17k) ............................................. Tramea cophysa

19' Discoidal space of FW consists of one to three cells and medial planate with one cell in

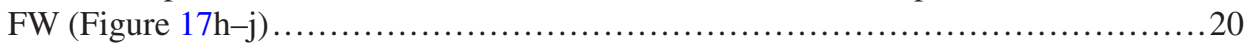

20 Mspl distinct, FW triangle crossed (Figure 18a), apical planate with one cell row proxi-

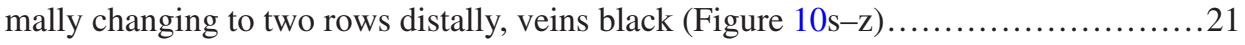
(Tauriphila)

20' Mspl indistinct, FW triangle free (Figure 18b, c), apical planate with one cells cell row, veins orange to red in mature specimens (Figure 8z, ac, ae) .............22 (Miathyria)

21 HW with dark basal patch extending to anal angle and reaching posterior wing margin or extensive amber wash in some females (Figure 10s, v). If in doubt, S3-10 lack black dorsally along distal portions ..................................... Tauriphila argo

21' HW with small dark basal patch, not reaching posterior wing margin (Figure 10w, z, aa). If in doubt, S3-10 black along distal margin or completely black........Tauriphila xiphea

22 Radial space of FW consists five to seven cells (Figure 18b). Frons metallic violet, brown or olive (Figure $8 \mathrm{aa}, \mathrm{ab})$. HW basal patch lengthened along proximal wing margin, not reaching triangle (Figures $8 \mathrm{z}$, ac, 17) ............................Miathyria marcella

22 Radial space of FW consists three or four cells (Figure 18c). Frons red, brown or olive (Figure 8ae). HW spot more rounded, reaching proximal side of triangle (Figure 8ad) Miathyria simplex 


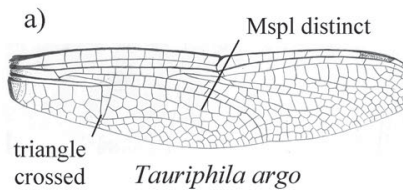

d)

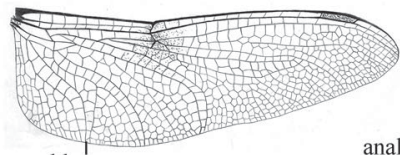

anal loop open Tholymis citrina

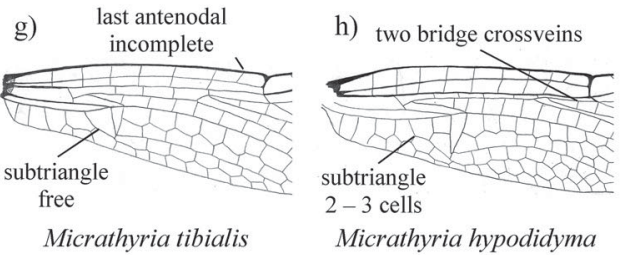

j) at most $81 / 2$ antenodals

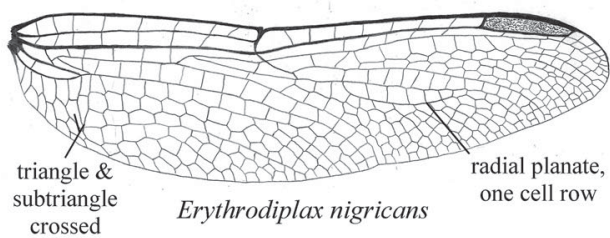

1)

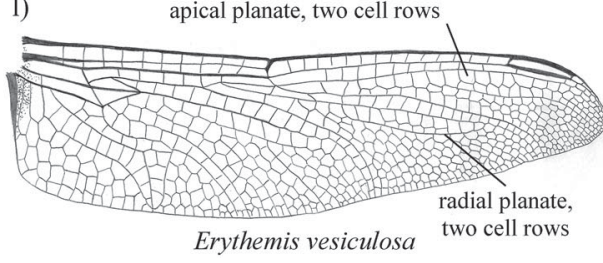

b)

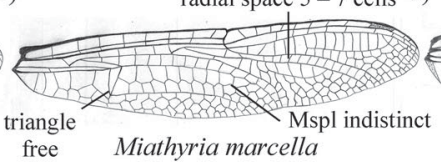

)

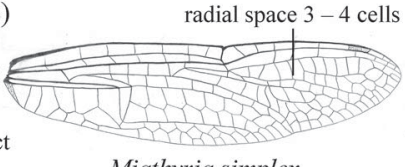

Miathyria simplex

f)
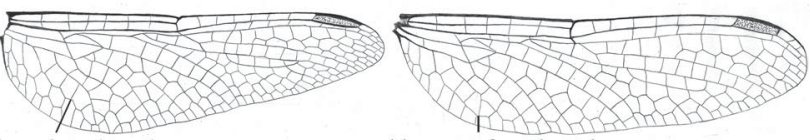

anal loop not foot shaped, at most 9 cells

Micrathyria tibialis

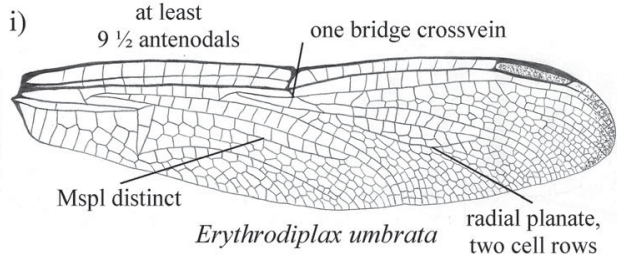

k)

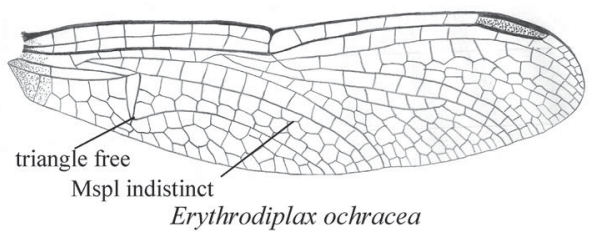

m)

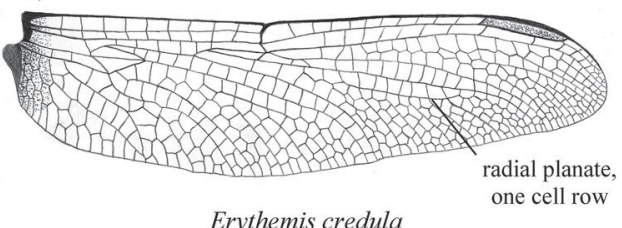

Figure 18. Key diagnostic features of Libellulidae species in Neembucú, part two: (a) FW of Tauriphila with Mspl distinct and triangle crossed, (b) FW with mspl indistinct, triangle free and radial space with 5-7 cells in Miathyria marcella, (c) radial space with 3-4 cells in Miathyria simplex. Anal loop (d) open in Tholymis citrina, (e) foot shaped, with at least 10 cells in Micrathyria spuria, and (f) not foot shaped with at most 9 cells in Micrathyria tibialis. Subtriangle (g) free, versus (h) two or three-celled. FW with two cell rows in radial planate, Mspl distinct and triangle and subtriangle crossed in (i) Erythrodiplax umbrata and (j) Erythrodiplax nigricans, versus (k) one cell row in radial planate, Mspl indistinct triangle free or crossed in Erythrodiplax ochracea. (1) Radial and apical planates with two cells rows distally in Erythemis vesiculosa, versus (m) radial planate with one cell row in other Erythemis spp.

23 HW anal loop open posteriorly, extending to edge of wing (Figure 18d) and yellow spot around HW nodus (Figure 10ab) .................................. Tholymis citrina

23' Anal loop closed (Figure 18e, f) and no yellow spot around HW nodus ................ 24

$24 \mathrm{AB}$ long ( $>42 \mathrm{~mm}$ ) (Figure 8v, y), longer than HW ............... Macrothemis lauriana

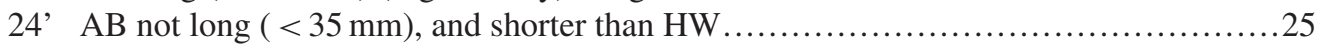

25 Discoidal space of FW with one row of cells at base and two bridge crossveins present (Figure $17 \mathrm{~h}$ ). Last antenodal crossvein in FW complete............ Nephepeltia aequisetis

25 Discoidal space of FW with two or more rows of cells; if one row, then only one bridge crossvein present (Figure 17i-k) ......................................... 26 
26 Two bridge crossveins, last antenodal always incomplete (Figure 18g-h). Lateral thorax with distinct stripes or irregular patterning (sometimes only marked around fossae in Micrathyria spuria) 27. . (Micrathyria)

26' One bridge crossvein (Figure 18i-k). Lateral thorax uniformly coloured (Figure 8g-r, 10a-

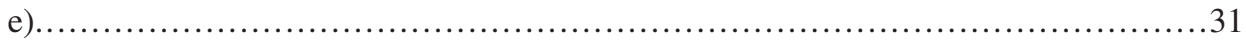

27 Lateral thorax with single pale oblique stripe running from anterodorsal to posterobasal corners (Figure 9e, h) ................................. Micrathyria longifasciata

27' Lateral thorax with two stripes running from anterobasal to posterodorsal corners (Figure 9a, d, s) or irregular pattern (Figure 9i, 1, m, p, r) ....................... 28

28 Lateral thorax with two pale stripes (Figure 9a, d, s). FW subtriangle two or three celled

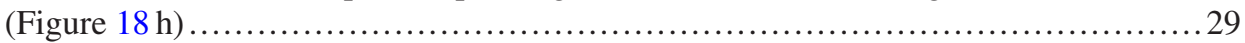

28' Lateral thorax with irregular pattern, lacking well-defined stripes (Figure 9i, 1, m, p, r).

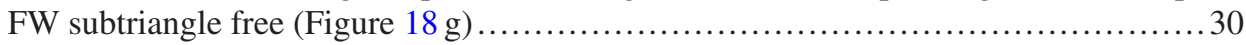

29 Male cerci, in lateral view, approximately linear (Figure 19s). Female cerci thin (Figure 19u). FW triangle free (Figure $18 \mathrm{~g}, 18 \mathrm{~g}, \mathrm{~h}$ ).............Micrathyria hypodidyma

29' Male cerci, in lateral view bent ventrally (Figure 19t). Female cerci thick (Figure 19v). FW triangle usually crossed (Figure $17 \mathrm{f})$.......................Micrathyria venezuelae

30 HW anal loop foot shaped, with at least 10 cells (Figure 18e). Pale stripes adjacent middorsal carina (Figure 9n, o). Vertex white tipped (Figure 9n, o) .............Micrathyria spuria

30' HW anal loop not foot shaped, with at most nine cells (Figure 18f). Lacks pale stripes adjacent to middorsal carina (Figure 9j, k). Vertex not white tipped (Figure 9j, k).Micrathyria tibialis

31 HW with small dark basal spot, or large amber-coloured area reaching first antenodal crossvein and anal angle vein. Body colour not mostly blue (Figure 8a-r) ............. 32 (Erythrodiplax)

31' Basal spot absent in HW, if amber tinge present, it does not extend more than two cells, so does not reach the first antenodal crossvein or anal angle. Body colour mostly blue (Figure 10a, b, e) $36($ Oligoclada $)$

32 Mspl distinct, triangle and subtriangle crossed (Figure 18i, j) ..................... 33

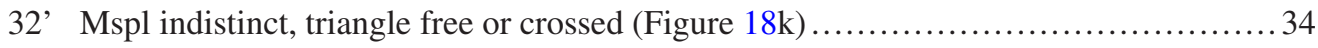

33 Two rows of cells in radial planate; FW with at least $91 / 2$ antenodal crossveins (Figure 18i) Erythrodiplax umbrata

33' One row of cells in radial planate; FW with at most $81 \frac{1}{2}$ antenodal crossveins (Figure 18j) Erythrodiplax nigricans

34 Large amber cloud at HW base reaching proximal side of triangle (Figure 8f, i). Head and $\mathrm{AB}$ colouration sometimes includes red but never blue (Figure $7 \mathrm{~g}, \mathrm{~h}$ )...... Erythrodiplax ochracea

34' HW patch not reaching triangle and generally not amber. Head and AB colouration

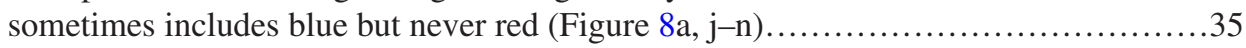

35 HW basal spot reaches first antenodal crossvein and almost triangle (Figure 8a). FW triangle crossed. HW length $>20 \mathrm{~mm} \ldots \ldots \ldots \ldots \ldots \ldots \ldots \ldots \ldots \ldots \ldots \ldots \ldots \ldots \ldots$ Erythrodiplax media

35 HW basal spot absent or small, only a few cells wide, not reaching first antenodal crossvein (Figure 8j, m, n). FW triangle usually free. HW length $\leq 20 \mathrm{~mm}$...........Erythrodiplax paraguayensis

36 S2-3 with dorsal red-orange spots (Figure 10b, e) Oligoclada rubribasalis

36' S2-3 without dorsal red-orange spots (Figure 10a) Oligoclada pachystigma 
37 Small reddish-brown spot surrounding nodus. AB short and thick; S4 width to length ratio 0.59 or more. Costal vein reddish-brown. Thorax of female and immature has small light coloured areas but lacks large patches or stripes (Figure 10h-k)...... Orthemis nodiplaga

a)

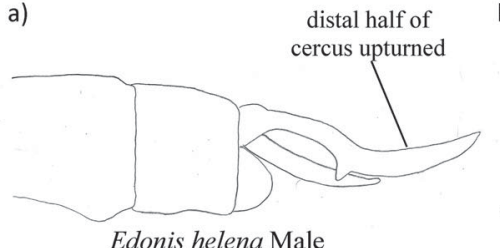

d)

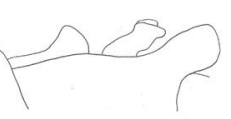

E. media

i)

median process $\geq$ lateral lobe length

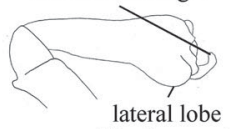

$<1 / 3$ of apex width

E. media e) hamule bent abruptly caudad

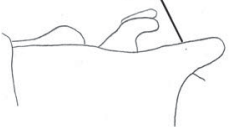

E. nigricans

j) E. nigricans

median process extends slightly beyond apex

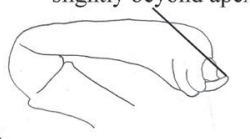

E. nigricans b)

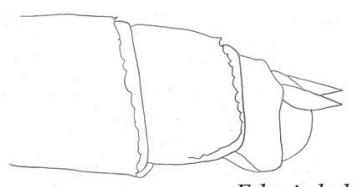

Edonis helena Female

f)

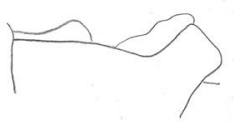

E. ochracea

k) distal lobes complex I) $\&$ largely hidden

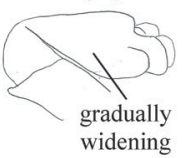

E. ochracea c)

g)

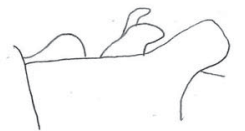

E. paraguayensis

median process $\geq$ lateral lobe length

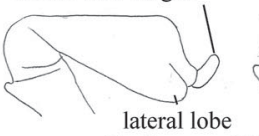

$\geq 1 / 2$ of apex width

E. paraguayensis
VL, V-shaped,

thickened edges
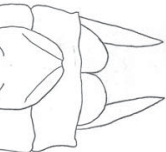

h)

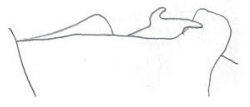

E. umbrata

m)

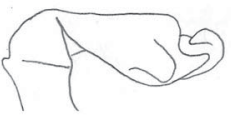

E. umbrata n)

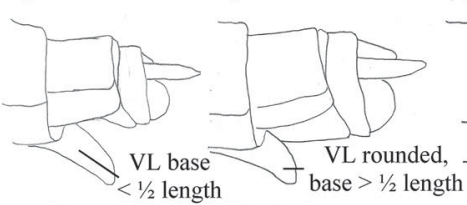

E. media

E. nigricans p) q) cercus apex

r)

Figure 19. Key diagnostic features of Libellulidae species in Neembucú, part three, genitalia: (a) Edonis helena male anal appendages in lateral view; Edonis helena female anal appendages in (b) lateral and (c) ventral view. (d-h) Male secondary genitalia of Erythrodiplax species in lateral view. (i-m) Male vesica spermalis of Erythrodiplax species in lateral view. (n-r). Abdominal tip of female Erythrodiplax species. Anal appendages, in lateral view of male (s) Micrathyria hypodidyma and (t) Micrathyria venezuelae, and female (u) Micrathyria hypodidyma and (v) Micrathyria venezuelae. (w) Anal appendage, in lateral view, of male Nephepeltia aequisetis. Anal appendages of male Oligoclada rubribasalis in (x) lateral and (y) ventral views; (z) anal appendages of male Oligoclada pachystigma, lateral view. Abdominal tip, ventral view, of female (aa) Oligoclada rubribasalis and (ab) Oligoclada pachystigma. Abdominal tip of Macrothemis lauriana, in lateral view, (ac) male and (ad) female. Female anal appendages in dorsal view of (ae) Orthemis aequilibris, and (af) Orthemis philipi. [Drawings (d-r) adapted from Borror (1942) in the public domain; (v) adapted from Figure 250 in Dragonflies of the Yungas (Odonata): a field guide to the species from Argentina by N. Von Ellenrieder and R. W. Garrison, Pensoft Publishers, (C) 2007, by permission of the authors; (w) adapted from Figure 13a in A synopsis of the Neotropical genus Nephepeltia (Odonata: Libellulidae), including description of a new species, synonymies, and a key to males by Natalia Von Ellenrieder, Zootaxa, (C) 2014, by permission of the authors; (x), (y) and (aa) adapted from Figures $6 \mathrm{a} \& 6 \mathrm{~b}$ and 7a in "The genus Oligoclada in Argentina, with description of O. rubribasalis sp. nov. (Odonata: Libellulidae)" by Natalia Von Ellenrieder and Rosser W. Garrison, International Journal of Odonatology, (C) 2008 Worldwide Dragonfly Association, by permission of Informa UK Limited, trading as Taylor \& Francis Group, www.tandfonline.com/loi/tijo20 on behalf of Worldwide Dragonfly Association; (z) and (ab) adapted by permission from Springer Nature: Section 3, Part 2: Anisoptera, Figure 3.2.316. In: Encyclopedia of South American Aquatic Insects: Odonata - Anisoptera by Charles W. Heckman (C) Springer 2006, https://doi.org/10.1007/978-1-4020-4802-5_3; (ae) adapted from Figure 17a in "Five new species of Orthemis from South America (Odonata: Libellulidae)", Natalia Von Ellenrieder, International Journal of Odonatology, () 2009 Worldwide Dragonfly Association, by permission of Informa UK Limited, trading as Taylor \& Francis Group, www.tandfonline.com/loi/tijo20 on behalf of Worldwide Dragonfly Association]. 


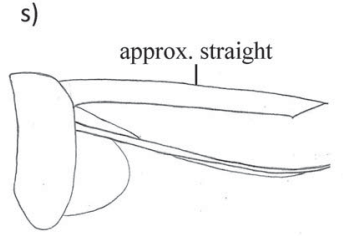

Micrathyria hypodidyma

$\mathrm{x})$

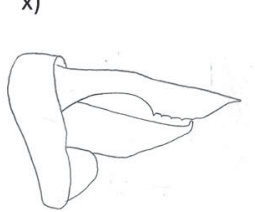

Oligoclada rubribasalis

ac)

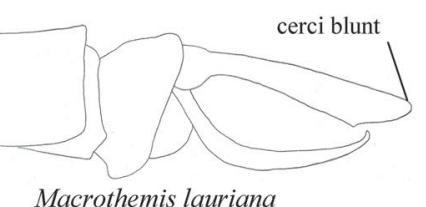

Macrothemis lauriana epiproct slightly t)

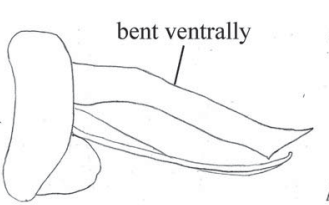

Micrathyria venezuelae

z) u)

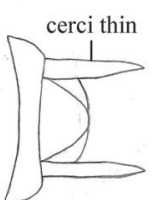

v)

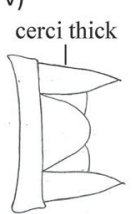

w)

ventral tooth $3 / 4$ distance to tip
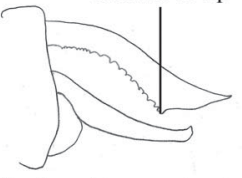

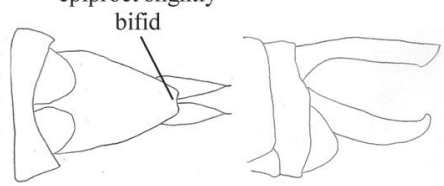

aа)

ab)

VL deeply V-shaped

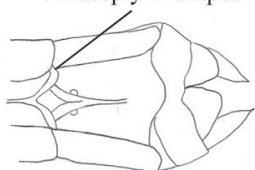

O. rubribasalis

Oligoclada pachystigma

ad)

ae) cerci length $<$ twice epiproct length

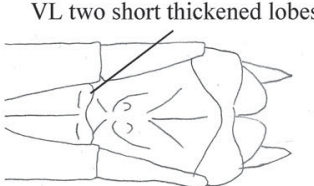

O. pachystigma

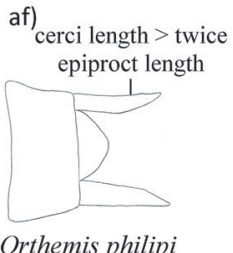

Figure 19. Continued.

37 Area around nodus hyaline. AB not short and thick; S4 width to length ratio less than 0.59 , sometimes constricted at S2-4. Costal vein black. Thorax of female and immature with large pale yellow spots or longitudinal stripes (Figure 10f, k l) .

38 AB relatively long and constricted at S2-4. Male AB red, female and immature with large pale yellow spots on pterothorax (Figure 101) ... Orthemis philipi

38' AB length moderate and parallel sided at S2-4. Male AB red or violet (Figure $9 \mathrm{~g}$ ), female and immature with two pale longitudinal stripes on pterothorax (Figure 10f).

39 Wing veins reddish brown. Male red (never violet), female and immature with two pale longitudinal stripes on pterothorax (Figure 10f) Orthemis aequilibris

39 Wing veins black. Male usually violet (Figure $10 \mathrm{~g}$ ), female and immature with two pale longitudinal stripes on pterothorax Orthemis discolor

40 HW basal spot small, not reaching media posterior crossvein or anal angle 41

40' HW basal spot large, reaches media posterior crossvein and sometimes anal angle.....42

41 Body colour green (Figure 6x, y). Two rows of cells in radial and apical planates (Figure 181) Erythemis vesiculosa

41' Body colour dark blue and red or mostly brown (Figure 7s-u). Radial planate with one cell row (Figure $18 \mathrm{~m}$ ) Erythemis peruviana

$42 \mathrm{AB}$ equal in length or longer than HW. Basal spot not reaching marginal row of anal angle (Figure 7v, w). Erythemis plebeja

42, AB shorter than HW.

43 HW basal spot reaches base of triangle and first antenodal crossvein at most (Figure 7i-k) 44

43' HW basal spot does not reach triangle and only sometimes reaching first antenodal crossvein (Figure $7 \mathrm{~m}, \mathrm{n}, \mathrm{p}, \mathrm{q}$ ) .... 


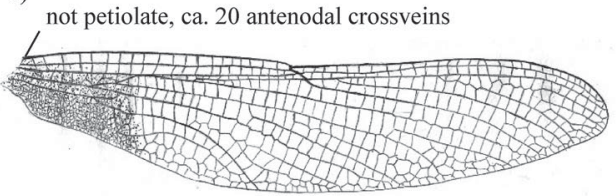

Hetaerina rosea

c)

petiolate, $2-4$ antenodal crossveins

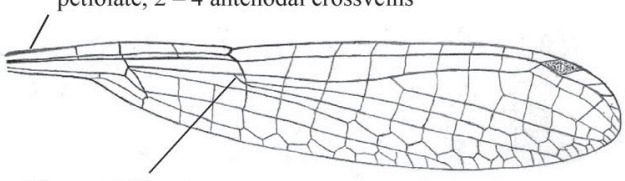

$\mathrm{IR}_{3+4}$ and $\mathrm{RP}_{2}$ arise nearer to arculus than subnodus
Ischnura fluviatilis

b)

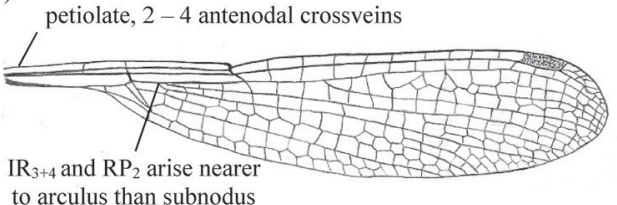

Lestes minutus

d)

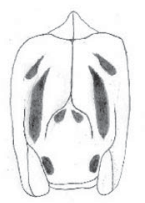

Lestes minutus e)

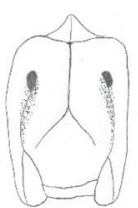

L. spatula f)

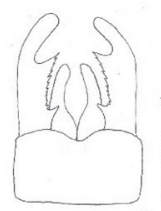

L. minutus g)

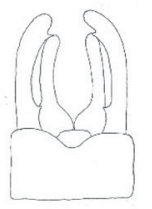

L. spatula

Figure 20. Key diagnostic features of Zygoptera families in Ñeembucú: (a) wing base not petiolate and with more than five antenodal crossveins in Calopterygidae (i.e. Hetaerina rosea); (b) wing distinctly petiolate and veins $\mathrm{IR}_{3}+4$ and $\mathrm{RP}_{2}$ arise nearer to arculus than subnodus in Lestidae; and (c) veins $\mathrm{IR}_{3+4}$ and $\mathrm{RP}_{2}$ arise nearer to subnodus than arculus in Coenagrionidae. Key differences between Lestidae species in Neembucú: patterning on venter of thorax in (d) Lestes minutus, and (e) Lestes spatula. Dorsal view of male cerci in (f) Lestes minutus, and (g) Lestes spatula. [Drawings (e) and (g) adapted from Figures 47 and 55 in Dragonflies of the Yungas (Odonata): a field guide to the species from Argentina by N. Von Ellenrieder and R. W. Garrison, Pensoft Publishers, (c) 2007, by permission of the authors].

44 Basal spot covers small basal region or row of marginal cells. Legs dark or pale only on distal portion of upper half. Body colour black with whitish marks on S7 or greenishbrown with dark brown distal portion on S4-7. S1-3 moderately widened (Figure 7i, j) Erythemis attala

44' Basal spot covers penultimate or marginal rows of cells. Legs pale. Body colour scarlet to reddish-brown or greenish-brown with dark brown dorsal and lateral markings on S3-7. S1-3 considerably widened (Figure $7 \mathrm{k}, 1) \ldots \ldots \ldots \ldots \ldots \ldots \ldots \ldots \ldots$ Erythemis carmelita

45 HW basal spot does not reach first antenodal crossvein. Body colour black, or yellowish with dark antehumeral stripes and black dorsal stripe on AB (Figure 7m-0, 18m). Erythemis credula

45 HW basal spot generally reaches first antenodal crossvein. Body colour red or ochraceous, lacks dark antehumeral stripes or black stripe on dorsal AB (Figure 7p-r)...... Erythemis mithroides

\section{KEY TO THE ZYGOPTERA OF ÑEEMBUCÚ}

1. Five or more antenodal crossveins in each wing, and wings not distinctly petiolate. Midbasal space subdivided by crossveins (Figure 20a).... . (Calopterygidae) Hetaerina rosea

1' Two to four antenodal crossveins in each wing, and wings distinctly petiolate (Figure 20b, c).

$2 \mathrm{IR}_{3+4}$ and $\mathrm{RP}_{2}$ arise nearer to arculus than subnodus (Figure 20b). Wings half spread at

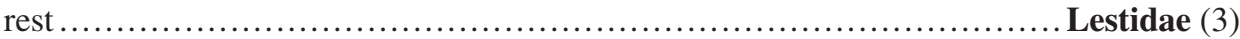

2' $\mathrm{IR}_{3+4}$ and $\mathrm{RP}_{2}$ arise nearer to subnodus than arculus (Figure 20c). Wings closed at rest. 


\section{Lestidae}

3 Venter of thorax with three pairs of large dark marks and one pair of small brown spots (Figure 20d)................................................estes minutus

3. Venter of thorax with two tiny black dots on anterior portion and two diffuse brown stripes (Figure 20e) Lestes spatula

\section{Coenagrionidae}

4 Frons angulated in lateral view, with a transverse carina (Figure 21a) .................5

4' Frons not angulated and without a transverse carina (Figure $21 \mathrm{~b}) \ldots \ldots \ldots \ldots \ldots \ldots \ldots \ldots . \ldots \ldots$

5 In lateral view, male cerci expanded at apex, distal margin of apex concave and tip of paraprocts proximal to ventral lobe (Figure 21c). Female mesanapleural suture with marked convexity and black spot in concavity (Figure 22a)....................Aeolagrion philipi

5 ' In lateral view, male cerci not vertically expanded at apex, distal margin of apex convex and tip of paraprocts reach at least as far posterior as cerci (Figure 21d-g). Female mesanapleural suture straight or slightly convex, without black spot in concavity........6 (Telebasis)

6 AB colour mostly blue or brown, with variable amount of black and middorsal thoracic stripe dark (Figure 120-t) . ... Telebasis obsoleta

6' AB mostly red, notably in dorsal view and middorsal thoracic stripe pale (Figure $12 \mathrm{u}-\mathrm{x}$ ) Telebasis willinki

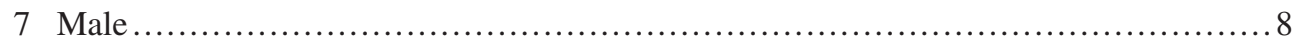

7' Female ..................................................................... 15

8 Postocular spots small, rounded, and pale blue to green (Figure 21h)........9 (Ischnura)

8' Postocular spots large and oval or elongated, or absent (Figure 21i, j) ............... 10

9 Rear of S10 raised, deeply forked and sharply curved. Cerci entire and paraprocts forked, and at least as long as S10 (Figure 21n)............................ Ischnura capreolus

9' Rear of S10 entire and not raised. Apex of cerci broadly rounded. Cerci bifid with subequal branches, paraprocts entire, curving dorsally with a pointed tip directed distally, shorter than S10 (Figure $21 \mathrm{~m}$ )..................................... Ischnura fluviatilis

10 Cerci directed obliquely ventrad from base and longer than S10 (Figure 21k, 1).......11 (Acanthagrion)

10' Cerci distally directed at base, much longer than paraprocts and with a ventral branch,

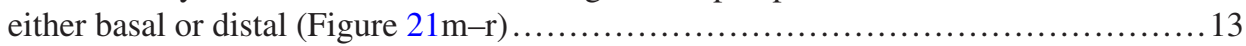

11 S10 distinctly raised higher than S9 (Figure 21k)...............Acanthagrion ascendens

11' S10 about same height as S9 (Figure 21 1) .................................... 12

12 S10 mostly blue. In lateral view, AB mostly blue with small black dorsal markings on posterodorsal regions of S2-7 (Figure $11 \mathrm{i}, \mathrm{j}$ )..................Acanthagrion temporale

12' S10 entirely black. In lateral view, S2-7 black along dorsal and posterior regions, blue

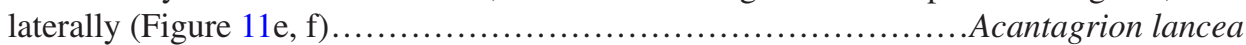

13 Posterior lobe of prothorax broadly bilobate (Figure 21s). Posterodorsal margin of S10 entire, cerci about twice as long as wide in dorsal view, in lateral view with distal portion bent ventrally at right angle and dorsal branch of paraprocts rounded (Figure 21o, p) . Argentagrion ambiguum

13' Posterior lobe of prothorax trilobate with differentiated trapezoidal or rectangular medial process (Figure 21t, u). Posterodorsal margin of S10 with U-shaped medial cleft with a tubercle on each side and cerci with ventrally directed laminar branch at base in lateral view (Figure 21q, r) 


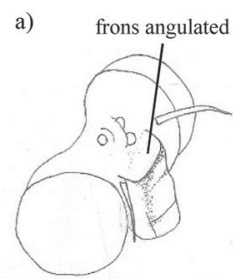

Telebasis willinki b)

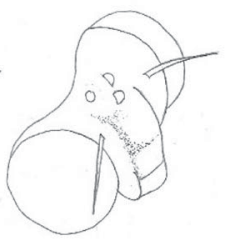

Ischnura fluviatilis

c) cercus apically expanded d) cercus not apically f)

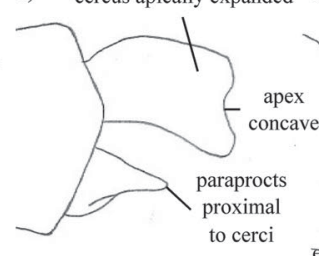

Aeolagrion philipi

i) postocular spots, elongate, bar present

small, round

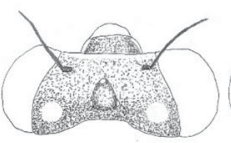

Ischnura capreolus

)
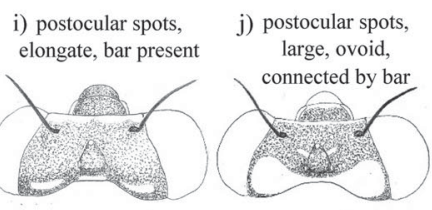

1)

m) entire, not raised

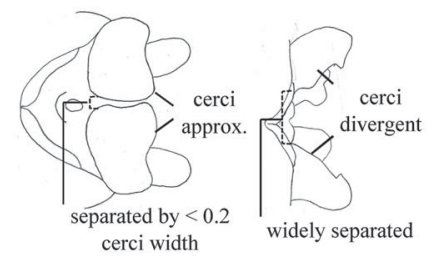

Telebasis obsoleta Telebasis willinki expanded

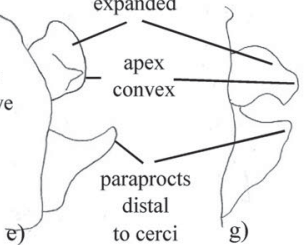

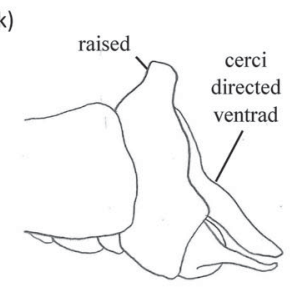

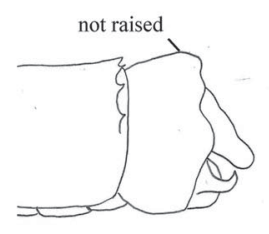

Acanthagrion lancea
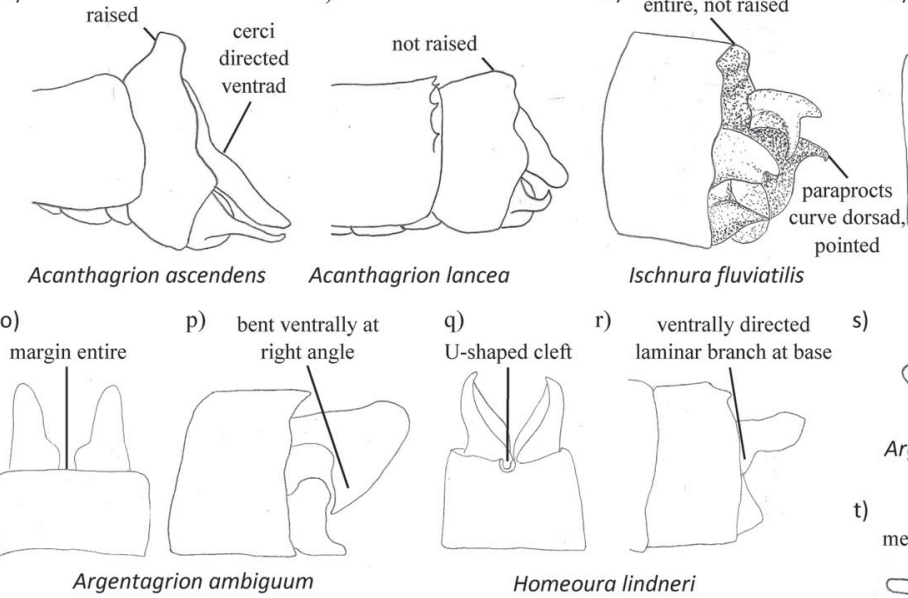

Ischnura fluviatilis

r) ventrally directed s) laminar branch at base

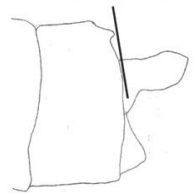

Homeoura lindneri

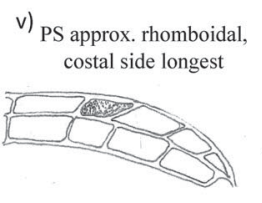

w) PS approx. rhomboidal, costal side longest

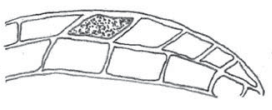

Homeoura lindneri x) PS approx. quadrangular, costal side shortest

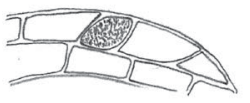

Homeoura nepos
Argentagrion ambiguum n) forked, raised

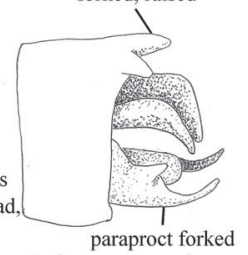

Ischnura capreolus

bilobate

Figure 21. Key diagnostic features of Coenagrionidae species in Neembucú, part one: (a) frons angulated with transverse carina versus (b) frons gradually curved without transverse carina; (c) lateral view of male cerci of Aeolagrion philipi; lateral and dorsal views of male cerci of (d, e) Telebasis obsoleta and (f, g) Telebasis willinki; post-ocular spots (h) small and round in male Ischnura, (i) small and elongate with postocular bar, or (j) large, ovoid and connected by postocular bar; male S10 and anal appendages, in lateral view, of (k) Acanthagrion ascendens, and (1) Acanthagrion lancea; mediodorsal view of S10 and anal appendages of (m) Ischnura fluviatilis and (n) Ischnura capreolus; dorsal and lateral views of male S10 and anal appendages of $(\mathrm{o}, \mathrm{p})$ Argentagrion ambiguum and (q, r) Homeoura lindneri; shape of male pronotum in (s) Argentagrion ambiguum; (t) Homeoura lindneri, and (u) Homeoura nepos; HW pterostigma shape in (v) Argentagrion ambiguum, (w) Homeoura lindneri, and (x) Homeoura nepos. [Drawings (d-g) adapted from "A synopsis of the genus Telebasis (Odonata: Coenagrionidae)" by R. W. Garrison, International Journal of Odonatology, copyright (C) 2009 Worldwide Dragonfly Association, by permission of Informa UK Limited, trading as Taylor \& Francis Group, www.tandfonline.com/loi/tijo20 on behalf of Worldwide Dragonfly Association; (k) and (1) adapted from Figures 107 and 188 in A revisionary study of the genus Acanthagrion (Odonata: Zygoptera) by J. Leonard, Miscellaneous Publications, (C) 1977 University of Michigan Museum of Zoology, by permission of University of Michigan Museum of Zoology; (a), (m) and (n) adapted from Figures 66, 117 and 119 in Dragonflies of the Yungas (Odonata): a field guide to the species from Argentina by N. Von Ellenrieder and R. W. Garrison, Pensoft Publishers, ( 2007, by permission of the authors; (o-x) adapted from Figures 14, 17, 19, 21, 27, 33, 66, 67, 78, 79, 80 and 81 in "Revalidation of Argentagrion and redefinition of Homeoura, with the description of H. obrieni n. sp. (Odonata: Coenagrionidae)" by Natalia Von Ellenrieder, Revista de la Sociedad Entomológica Argentina, by permission from Natalia Von Ellenrieder @ 2008] 
a)

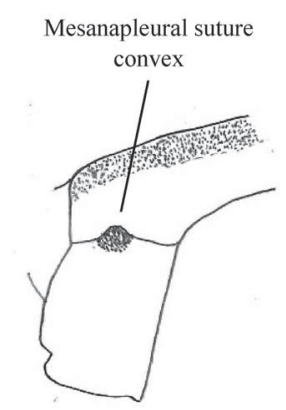

Aeolagrion phillipi g) trilobate, with medial cleft

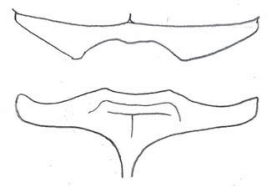

Ischnura capreolus b)

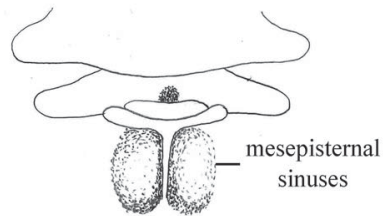

Telebasis obsoletum

c) 'cup-like' mesepisternal

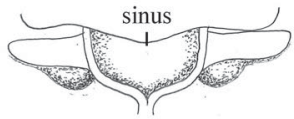

Telebasis willinki

h) mesostigmal plates form rhomboidal structure

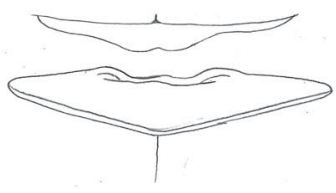

Ischnura fluviatilis d)

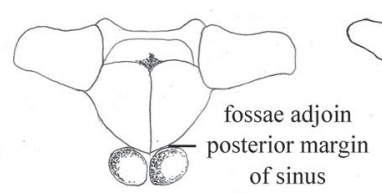

f)

\section{Acanthagrion lancea}

e)

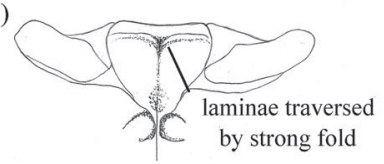

Acanthagrion temporale Acanthagrion ascendens

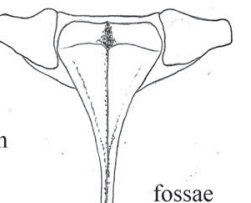

separated from

- sinus by $>2 \mathrm{X}$ their length i) bilobate

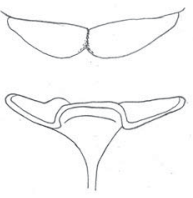

\section{Argentagrion} ambiguum j) medial projection
triangular

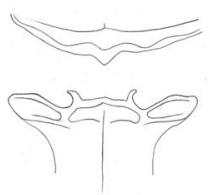

Homeoura lindneri k) trilobate, medial projection approx. rectangular, sinuous

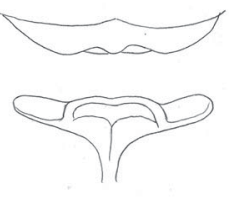

Homeoura nepos

Figure 22. Key diagnostic features of Coenagrionidae species in Ñeembucú, part two, females: (a) mesanapleural suture with marked dorsal convexity and black mark below in Aelagrion philipi; pronotum and mesostigmal plates of (b) Telebasis obsoleta and (c) Telebasis willinki; mesostigmal plates of (d) Acanthagrion lancea, (e) Acanthagrion temporale, and (f) Acanthagrion ascendens; and pronotum (above) and mesostigmal plates (below) of (g) Ischnura capreolus, (h) Ischnura fluviatilis, (i) Argentagrion ambiguum, (j) Homeoura lindneri, and (k) Homeoura nepos. [Drawings (d-f) adapted from Figures 144, 154 and 157 in A revisionary study of the genus Acanthagrion (Odonata: Zygoptera) by J. Leonard, Miscellaneous Publications, (C) 1977 University of Michigan Museum of Zoology, by permission of University of Michigan Museum of Zoology; (g) and (h) adapted from Figures 120 and 122 in Dragonflies of the Yungas (Odonata): a field guide to the species from Argentina by N. Von Ellenrieder and R. W. Garrison, Pensoft Publishers, () 2007, by permission of the authors; (i-k) adapted from Figures 23-26 and 34-35 in "Revalidation of Argentagrion and redefinition of Homeoura, with the description of H. obrieni n. sp. (Odonata: Coenagrionidae)" by Natalia Von Ellenrieder, Revista de la Sociedad Entomológica Argentina, by permission from Natalia Von Ellenrieder @ 2008].

14 PS approximately quadrangular, with costal side the shortest (Figure 21x). Medial portion of posterior lobe of prothorax approximately rectangular, with posterior margin slightly concave to linear (Figure 21u) Homeoura nepos

14' PS approximately rhomboidal, with costal side the longest (Figure 21w). Medial portion of posterior lobe of prothorax approximately rhomboidal with posterior margin convex (Figure 21t). Homeoura lindneri

15 Mesepisternal fossae present (Figure 22d-f) 16 (Acanthagrion)

15. Mesepisternal fossae absent (Figure 22g-k) .... 18

16 Mesostigmal laminae diagonally traversed by a strong fold (Figure 22e).... Acanthagrion temporale

16' Mesostigmal laminae not diagonally transversed by a strong fold (Figure 22d, f)

17 Mesepisternal fossae separated from posterior end of sinus by more than twice their own length, their long axis parallel to middorsal carina (Figure 22f)..Acanthagrion ascendens

17' Mesepisternal fossae adjoining posterior margin of interlaminal sinus, their long axis transverse to middorsal carina (Figure 22d) ......................Acanthagrion lancea

18 Posterior lobe of pronotum with medial cleft (Figure $22 \mathrm{~g}$ ). Ischnura capreolus 
18' Posterior lobe of pronotum without medial cleft (Figure 22h-k)

19 Mesostigmal plates of both sides confluent, forming a single rhomboidal structure (Figure $22 \mathrm{~h}$ ) Ischnura fluviatilis

19' Mesostigmal plates separated or, if confluent, do not form a single rhomboidal structure (Figure 22i-k) 20

20 Posterior lobe of prothorax widely bilobate (Figure 22i) Argentagrion ambiguum

20' Posterior lobe of prothorax trilobate with a differentiated triangular or rectangular medial process (Figure 22j, k)...

21 PS quadrangular, with costal side the shortest (Figure 21x). Medial projection of posterior lobe of prothorax reduced, approximately rectangular with posterior margin slightly sinuate. Lateral margins of mesostigmal plates bluntly rounded, anterior and posterior margins approximately parallel (Figure 22k) Homeoura nepos

21' PS rhomboidal, with costal side the longest (Figure 21w). Medial projection of posterior lobe of prothorax triangular. Lateral margins of mesostigmal plates bluntly pointed, anterior and posterior margins not parallel (Figure 22j)

Homeoura lindneri

\section{Discussion}

The 60 species recorded in Neembucú represent 33\% of species known from Paraguay, whilst $11(18 \%)$ were new country records, raising the total number of species known from the country from 133 (Paulson, 2004) to 141. This suggests that the total number of species listed for the country is substantially underestimated. In fact, the proportion of species that are new records is similar to that found during a study on butterflies in Paraguay (Dickens, McMahon, \& Binnie, 2019), which estimated that up to half the species present in the country had not yet been recorded. Whether the degree of underestimation is as large for the Odonata is unclear. However, the country total is around half that of the neighbouring states of Brazil (Bedê et al., 2015) and Argentina (Von Ellenrieder \& Muzón, 2008), which share the same bioregions, and suggest that it is indeed substantial. Furthermore, the species list for Neembucú is clearly also incomplete with much of the department remaining unsurveyed, whilst some of the larger and faster flying species may have evaded capture. Therefore, sampling in previously unsurveyed areas, especially along streams, and the use of different collection techniques would likely increase the number of species recorded.

Nevertheless, the recorded species richness and composition for Neembucú are similar to the Eastern portion of the Argentine Chaco, which has 53 recorded species (Von Ellenrieder, 2010). This is unsurprising given its geographic proximity, although it covers a larger area. The recorded species richness is also only slightly lower than for the world-renowned Iberá Wetlands, $100 \mathrm{~km}$ to the south in Corrientes, Argentina, with 75 recorded species (Muzón et al., 2008), although this was recorded over a longer period (six years) and falls within the range of the total number of species estimated to occur in Neembucú. However, the species composition in Neembucú is notably different to that of Iberá (Muzón et al., 2008), despite the fact that they both fall within the correntino complex of the Chaco biome (The Nature Conservancy et al., 2005). The similar physiognomies, limnology and climate (Neiff, 2003; Poi de Neiff, 2003) between these regions rules them out as potential drivers. Rather, it suggests that they are the result of different biogeographical histories (centres of endemism and river basins). In this case, the Odonata of the Ñeembucú Wetlands clearly have a close affinity to the Chaco biome, although elements from the Andes-Patagonia-Pampas subregion and the Paraná River basin are present. On the other hand, the Odonata of the Iberá Wetlands have a strong affinity to the Paraná River basin (Muzón et al., 
2008), even though the terrestrial plant communities are Chacoan. Similar cases of Odonata compositional differences between nearby sites with similar environmental conditions across biogeographical boundaries are well documented elsewhere in South America (Brasil, Vieira, De Oliveira-Junior, Dias-Silva, \& Juen, 2017; Juen, Cabette, \& De Marco, 2007; Juen \& De Marco, 2012). Therefore, patterns of Odonata diversity across South America are best understood in a historical biogeographical framework, although the exact positions of the boundaries between biogeographical regions are unclear because they are influenced by both terrestrial and freshwater ecoregions and require further investigation.

Furthermore, the partitioning of species from different biogeographical regions in different habitats in Ñeembucú is highly characteristic of a regional ecotone since the local distribution of species is constrained by their interactions with keystone environmental structures (vegetation, aquatic habitat and microclimate) and other species (Gosz, 1993; Kirkman, Drew, West, \& Blood, 1998; Risser, 1995; Tews et al., 2004). Von Ellenrieder (2000) observed similar trends in the subtropical forest-pampas ecotone in Buenos Aires with subtropical species (including Telebasis willinki) restricted to the forest and Lestes species and other temperate species to the grasslands. The resultant blend of species is responsible for the elevated levels of species richness so characteristic of such ecotones (Brothers, 1993; Carter, Gammon, \& Garrett, 1994; Risser, 1995; Shmida \& Wilson, 1985; Wolf, 1993).

In terms of the selection of indicator species, several species are strongly associated with wetland types, making them reliable indictors of these habitats. Von Ellenrieder (2010) conducted a similar indicator species analysis for wetlands of the Argentine Humid Chaco but the species selected are some of the most common and widespread species in Neembucú. This is testament to the massive extent and good health of wetlands in the Neembucú and includes E. peruviana, E. ochracea, E. paraguayensis and to a lesser extent A. ambiguum, E. umbrata, and M. longifasciata for marshes and T. willinki, M. marcella, and to a lesser extent D. intensa, E. plebeja and $P$. mooma for large permanent lentic waterbodies. In this study, however, we found T. willinki to be more specifically associated with large permanent wetlands and nearby temporary wooded wetlands (in winter), whilst $P$. mooma had a strong association with the Paraguay River and nearby temporary grassy wetlands. Unfortunately, sample sizes were too small for $D$. intens $a$ and E. plebeja to be considered potential indicator species. However, D. intensa had a strong fidelity to the river but was also recorded at large permanent wetlands, temporary wooded wetlands and along the forest edge. E. plebeja, on the other hand, had a strong association with large permanent wetlands and wooded temporary wetlands. Further sampling is required across more sites to confirm the association of these more weakly associated species to wetland types.

The unique diversity of the Neembucú Wetlands indicates their high conservation potential. Previous attempts to identify priority areas for biodiversity conservation in the Chaco biome have consistently earmarked the Neembucú region (Nori, Torres, Lescano, Cordier, Periago, \& Baldo, 2016; The Nature Conservancy et al., 2005) but this has been restricted to the use of vertebrate groups and ecosystems. This study offers the first evidence of their importance for the conservation of invertebrates. This is particularly true for species endemic or near endemic to the Chaco and Pampas biomes and/or the Paraná and/or Paraguay River basins and those with localised distributions. Additionally, the large permanent wetlands, in particular, appear to play a critical role in maintaining the regional diversity by acting as refugia during dry periods for species also associated with temporary wetlands. Although we found species associated with temporary habitats in combination with large permanent wetlands (Table 2 and 3), this survey was carried out entirely within a wet cycle (La Niña). However, in dry periods (El Niño), most these temporary habitats will dry up completely, leaving only the perimeter of large permanent wetlands as habitat for these species. Even within this study, species associated with temporary wetlands became largely restricted to the large permanent wetlands during the dry season. This was most evident in M. spuria and L. minutus. 
In order to prevent any further degradation and improve the current environmental condition of the Neembucú Wetlands, we recommend the following actions: (1) preventing wetland drainage and (2) restoring previously drained sites; (3) implementing environmentally sound road building practices, especially with regards to alterations to water flow; (4) implementing of controlled grazing practices; (5) enforcing national regulations surrounding agrochemical usage; (6) raising awareness about the importance of wetlands; (7) fostering stewardship of local landowners and (8) promoting Odonata as a flagship group for the protection of wetlands, especially by (9) highlighting their crucial role in public health by reducing the prevalence of mosquito-borne diseases, such as dengue (Saha, Aditya, Banerjee, \& Saha, 2012; Shaalan \& Canyon, 2009).

\section{Acknowledgements}

We thank Fundación Para La Tierra for supporting this research through the provision of all the necessary resources. We thank Odilon Barrios for access to Estancia Santa Ana and Coronel Alberto Torres Nuñez for access to the Regimiento de Caballeria $N^{\circ} 2$ "Cnel Felipe Toledo". We also thank all the volunteers and interns who assisted with surveys. We declare that we have no conflict of interest. The Secretaria del Ambiente (SEAM) granted permits for the collection of specimens.

\section{Supplemental data}

Supplemental data for this article can be accessed at https://doi.org/10.1080/13887890.2020.1768157

\section{ORCID}

Jeremy Kenneth Dickens (D) http://orcid.org/0000-0002-6993-0404

Daniel Schoenberger (D) http://orcid.org/0000-0002-8790-6993

Michelle VanCompernolle (D) http://orcid.org/0000-0002-8983-0443

\section{References}

Acreman, M. C., \& Mountford, J. O. (2009). Wetland Management. In Catchment management handbook (pp. 19-50). Oxford: Wiley-Blackwell.

Aveiro-Talavera, J. J. (n.d.). Neembucú Wetlands: Integrated management Overview. Manitoba, Canada.

Bedê, L. C., Machado, A. B. M., Piper, W., \& Souza, M. M. De. (2015). Odonata of the Serra de São José - Brazil's first Wildlife Reserve aimed at the conservation of dragonflies. Notulae Odonatologicae, 8(5), 117-155.

Belle, J. (1992). A revision of the South American species of Aphylla Selys, 1854 (Odonata: Gomphidae). Zoologishce Mededelingen Leiden, 66(12), 239-264.

Borror, D. J. (1931). The genus Oligoclada (Odonata). Miscellaneous Publications, University of Michigan Museum of Zoology, 22(April 30), 1-58.

Borror, D. J. (1942). A revision of the libelluline genus Erythrodiplax (Odonata). Contributions in Zoology and Entomology, 4(27), xv +286.

Brasil, L. S., Vieira, T. B., De Oliveira-Junior, J. M. B., Dias-Silva, K., \& Juen, L. (2017). Elements of metacommunity structure in Amazonian Zygoptera among streams under different spatial scales and environmental conditions. Ecology and Evolution, 7(9), 3190-3200. https://doi.org/10.1002/ece3.2849

Brothers, T. S. (1993). Fragmentation and edge effects in central Indiana old-growth forests. Natural Areas Journal, 13(4), 268-275.

Brown, K. S. J. (1991). Conservation of insects and their habitats: insects as indicators. In N. M. Collins \& J. A. Thomas (Eds.), The conservation of insects and their habitats (pp. 350-404). London: Academic Press.

Carter, V., Gammon, P. T., \& Garrett, M. K. (1994). Ecotone dynamics and boundary determination in the Great Dismal Swamp. Ecological Applications, 4, 189-203.

Clark, T. E., \& Samways, M. J. (1996). Dragonflies (Odonata) as indicators of biotope quality in the Kruger National Park, South Africa. The Journal of Applied Ecology, 33(5), 1001. https://doi.org/10.2307/2404681

Contreras, J. R. (2003). El valle aluvial del río Paraguay como "caja de resonancia" de la oscilación climática "El Niño": su influencia en el Paraguay natural e histórico. Historia Paraguaya, Anuario de La Academia Paraguaya de La Historia, Asunción, XLIII, 545-587.

Contreras Roqué, J. R., Contreras Chialchia, A. O., \& Delpino Aguayo, M. (2007). Estudios bioecológicos sobre los humedales del Ñeembucú: desarollo urbano y antropización creciente del medio natrual en el departamento del 
Neembucú al sur del Río Tebicuary, República del Paraguay. Pilar, Paraguay: Univeridad Nacional de Pilar y Fundación de Historia Natural Félix de Azara.

De Cáceres, M., \& Jansen, F. (2016). Package ‘indicspecies’ (Version 1.7.6). R Package Vignettes, 1-31.

De Cáceres, M., \& Legendre, P. (2009). Associations between species and groups of sites: indices and statistical inference. Ecology (Vol. 90). Retrieved from http://biodiversitat.ctfc.es/ECOLAND/Publicacions/Articles_SCI/ De_Caceres_\&_Legendre_Ecology_2009.pdf

De Selys Longchamps, M. (1878). Additions au Synopsis des Gomphines (suite et fin), Légions: Lindenia: Chlorogomphus: Cordulegaster et Petalura. Bulletins de l'Académie Royale Des Sciences, Des Lettres et Des Beaux-Arts de Belgique, 2(46), 658-698.

Dickens, J. K., McMahon, L., \& Binnie, S. E. (2019). The butterflies of a Cerrado-Atlantic Forest ecotone at Laguna Blanca reveal underestimation of Paraguayan butterfly diversity and need for conservation. Journal of Insect Conservation, 23(4), 707-728. https://doi.org/10.1007/s10841-019-00165-7

Dinerstein, E., Olson, D. M., Graham, D. J., Webster, A. L., Primm, S. A., Bookbinder, M. P., \& Ledec, G. (1995). Una Evaluación del Estado de Conservación de las Ecoregiones Terrestres de América Latina y el Caribe. Washington, DC: World Bank.

Duarte, D. R. G. (2000). Bosquejo geológico de los esteros del Ñeembucú. Pilar, Paraguay: Univeridad Nacional de Pilar.

Dufrêne, M., \& Legendre, P. (1997). Species assemblages and indicator species: The need for a flexible asymmetrical approach. Ecological Monographs, 67(3), 345-366. https://doi.org/10.1016/j.dld.2016.07.010

Garrison, R. W. (2009). A synopsis of the genus Telebasis (Odonata: Coenagrionidae). International Journal of Odonatology, 12(1), 1-121. https://doi.org/10.1080/13887890.2009.9748331

Garrison, R. W., Von Ellenrieder, N., \& Louton, J. A. (2006). Dragonfly Genera of the New World: an illustrated and annotated key to the Anisoptera. Baltimore, Maryland: The Johns Hopkins University Press.

Garrison, R. W., Von Ellenrieder, N., \& Louton, J. A. (2010). Damselfly Genera of the New World: an illustrated and annotated key to the Zygoptera. Baltimore, Maryland: The Johns Hopkins University Press.

Golfieri, B., Hardersen, S., Maiolini, B., \& Surian, N. (2016). Odonates as indicators of the ecological integrity of the river corridor: Development and application of the Odonate River Index (ORI) in northern Italy. Ecological Indicators, 61, 234-247. https://doi.org/10.1016/j.ecolind.2015.09.022

Gosz, J. R. (1993). Ecotone Hierarchies. Ecological Applications, 3(3), 369-376.

Hales, J., \& Petry, P. (2015). Freshwater ecoregions of the world. Retrieved June 20, 2019, from http://www.feow.org

Heckman, C. W. (2006). Encyclopedia of South American Aquatic Insects: Odonata - Anisoptera. https://doi.org/ 10.1007/978-1-4020-4802-5

Heckman, C. W. (2008). Encyclopedia of South American Aquatic Insects: Odonata - Zygoptera. https://doi.org/ 10.1007/978-1-4020-8176-7

Hortal, J., De Bello, F., Diniz-Filho, J. A. F., Lewinsohn, T. M., Lobo, J. M., \& Ladle, R. J. (2015). Seven Shortfalls that Beset Large-Scale Knowledge of Biodiversity. Annual Review of Ecology and Systematics, 46(October), 523-549. https://doi.org/10.1146/annurev-ecolsys-112414-054400

Hsieh, T. C., Ma, K. H., \& Chao, A. (2016). iNEXT: an R package for rarefaction and extrapolation of species diversity (Hill numbers). Methods in Ecology and Evolution, 7(12), 1451-1456. https://doi.org/10.1111/2041-210X.12613

Juen, L., Cabette, H. S. R., \& De Marco, P. (2007). Odonate assemblage structure in relation to basin and aquatic habitat structure in Pantanal wetlands. Hydrobiologia, 579(1), 125-134. https://doi.org/10.1007/s10750-006-0395-6

Juen, L., \& De Marco, P. (2012). Dragonfly endemism in the Brazilian Amazon: Competing hypotheses for biogeographical patterns. Biodiversity and Conservation, 21(13), 3507-3521. https://doi.org/10.1007/s10531-012-0377-0

Kalkman, V. J., Clausnitzer, V., Dijkstra, K. D. B., Orr, A. G., Paulson, D. R., \& Van Tol, J. (2008). Global diversity of dragonflies (Odonata) in freshwater. Hydrobiologia, 595(1), 351-363. https://doi.org/10.1007/s10750-007-9029-X

Kirkman, L. K., Drew, M. B., West, L. T., \& Blood, E. R. (1998). Ecotone characterization between upland longleaf pine/wiregrass stands and seasonally-ponded isolated wetlands. Wetlands, 18, 346-364.

Kottek, M., Grieser, J., Beck, C., Rudolf, B., \& Rubel, F. (2006). World map of the Köppen-Geiger climate classification updated. Meteorologische Zeitschrift, 15(3), 259-263. https://doi.org/10.1127/0941-2948/2006/0130

Kutcher, T. E., \& Bried, J. T. (2014). Adult Odonata conservatism as an indicator of freshwater wetland condition. Ecological Indicators, 38, 31-39. https://doi.org/10.1016/j.ecolind.2013.10.028

Lencioni, F. A. A. (2006). Damselfies of Brazil: an illustrated identification guide 2 - Coenagrionidae. Brazil: All Print Editora.

Leonard, J. W. (1977). A revisionary study of the genus Acanthagrion (Odonata: Zygoptera). Miscellaneous Publications, University of Michigan Museum of Zoology, (153), 188.

Maltby, E. (2009). Functional assessment of wetlands: towards evaluation of ecosystem services. Oxford, Cambridge and New Delhi: Woodhead Publishing Ltd.

Marmels, J. De, \& Rácenis, J. (1982). An analysis of the cophysa-group of Tramea Hagen, with descriptions of two new species (Anisoptera: Libellulidae). Odonatologica, 11(2), 109-128.

May, M. L. (1998). Macrothemis fallax, a new species of dragonfly from Central America (Anisoptera: Libellulidae), with a key to male Macrothemis. International Journal of Odonatology, 1(2), 137-153. https://doi.org/10.1080/13887890.1998.9748101

Mereles, F., Vera, H., Motte, M., Morales, C., Clay, R. P., Castillo, H. del, \& Cartes, J. L. (2005). Conocimiento de la biodiversidad Paraguaya en el Río Paraguay. Asunción: TBN/Guyra Paraguay.

Muzón, J., Von Ellenrieder, N., Pessacq, P., Lozano, F., Garré, A., Lambruschini, J., \& Weigel Muñoz, S. (2008). Odonata from Iberá Wetlands (Corrientes, Argentina): preliminary inventory and biodiversity. Cambridge, MA: Academic Press. Revista de la Sociedad Entomológica Argentina, 67(1-2), 59-67. 
Neiff, J. J. (2001). Diversity in some tropical wetland systems of South America. In Biodiversity in wetlands: Assessment, function and conservation, volume 2 (pp. 157-186). Leiden, The Netherlands: Backhuys Publishers.

Neiff, J. J. (2003). Distribucion de la vegetacion acuatica y palustre del Iberá. In A. Poi de Neiff (Ed.), Limnología del Iberá (pp. 17-70). Corrientes, Argentina: Universidade Nacional del Nordeste.

Nori, J., Torres, R., Lescano, J. N., Cordier, J. M., Periago, M. E., \& Baldo, D. (2016). Protected areas and spatial conservation priorities for endemic vertebrates of the Gran Chaco, one of the most threatened ecoregions of the world. Diversity and Distributions, 22(12), 1212-1219. https://doi.org/10.1111/ddi.12497

Oksanen, J., Blanchet, F. G., Kindt, R., Legendre, P., Minchin, P. R., O’hara, R. B., \& Oksanen, M. J. (2013). Package 'vegan'. Community ecology package, version 2. 9.

Olson, D. M., Dinerstein, E., Wikramanayake, E. D., Burgess, N. D., Powell, G. V. N., Underwood, E. C., \& Kassem, K. R. (2001). Terrestrial ecoregions of the world: a new map of life on Earth. BioScience, 51(11), 933-938.

Paulson, D. R. (2004). Critical species of Odonata in the Neotropics. International Journal of Odonatology, 7(2), 163 188.

Poi de Neiff, A. (2003). Limnología del Iberá. Aspectos físicos, quimicos y biologicos de las aguas. Argentina: Editorial Universitaria de la Universidad Nacional del Noreste.

QGIS Development Team. (2019). QGIS Geographic Information System. Open Source Geospatial Foundation Project. Retrieved from http://qgis.osgeo.org

Quirós, R. (2003). The Plata River Basin: international basin development and riverine fisheries. In Proceedings of the Second International Symposium on the Management of Large Rivers for Fisheries (Vol. 1, pp. 253-271). Buenos Aires, Argentina: Food and Agricultural Organisation of the United Nations.

R Development Core Team. (2015). R: A language and environment for statistical computing. $R$ Foundation for Statistical Computing. Vienna, Austria.

Realpe, E. (2010). Two new Andean species of the genus Ischnura Charpenteir from Colombia, with a key to the regional species (Zygoptera: Coenagrionidae). Odonatologica, 39(2), 121-131.

Riek, E. F., \& Kukalová-Peck, J. (1984). A new interpretation of dragonfly wing venation based upon Early Upper Carboniferous fossils from Argentina (Insecta: Odonatoidea) and basic character states in pterygote wings. Canadian Journal of Zoology, 62(6), 1150-1166. https://doi.org/10.1139/z84-166

Risser, P. R. (1995). The status of the science examining ecotones - a dynamic aspect of landscape is the area of steep gradients between more homogeneous vegetation associations. Bioscience, 45(5), 318-325.

Rodríguez, F. P., Sarmiento, C., \& González-Soriano, E. (2015). Morphological variability and evaluation of taxonomic characters in the genus Erythemis Hagen, 1861 (Odonata: Libellulidae: Sympetrinae). Insecta Mundi: A Journal of World Insect Systematics, 1861, 1-68.

Rodríguez, J. S., \& Molineri, C. (2013). Diversidad del orden Odonata (Fabricius, 1793) en la provincia de Tucumán, Argentina. Acta Zoológica Lilloana, 57(1), 22-30.

Saha, N., Aditya, G., Banerjee, S., \& Saha, G. K. (2012). Predation potential of odonates on mosquito larvae: Implications for biological control. Biological Control, 63(1), 1-8. https://doi.org/10.1016/j.biocontrol.2012.05.004

Samways, M. J. (2008). Dragonflies as focal organisms in contemporary conservation biology. In A. Córdoba-Aquilar (Ed.), Dragonflies and Damselflies: Model Organisms for Ecological and Evolutionary Research (pp. 97-108). Oxford, UK: Oxford University Press.

Shaalan, E. A. S., \& Canyon, D. V. (2009). Aquatic insect predators and mosquito control. Tropical Biomedicine, 26(3), 223-261.

Shmida, A., \& Wilson, M. V. (1985). Biological Determinants of Species Diversity. Journal of Biogeography, 12, 1-20.

Souza, L. O. I. de, Costa, J. M., \& Santos, T. C. (2010). Revalidation of Acanthagrion cuyabae (Odonata, Coenagrionidae) and description of the female, with a key to the Brazilian species of the viridescens group. Iheringia. Série Zoologia, 100(1), 79-83. https://doi.org/10.1590/s0073-47212010000100011

Suhling, F., Sahlén, G., Gorb, S., Kalkman, V. J., Dijkstra, K.-D. B., \& Tol, J. van. (2015). Order Odonata. In T. James \& D. C. Rogers (Eds.), Ecology andgeneral biology. Thorp and Covich's Freshwater Invertebrates (4th ed.) (pp. 893-932). Cambridge, MA: Academic Press.

Tennessen, K. J. (2001). Coryphaeschna huaorania spec. nov. from central Ecuador with keys to all species in the genus (Odonata: Aeshnidae). International Journal of Odonatology, 4(1), 71-81. https://doi.org/10.1080/13887890.2001. 9748160

Tennessen, K. J. (2009). Aeolagrion philipi sp. nov. from Bolivia, and a review of the genus Aeolagrion (Odonata: Coenagrionidae). International Journal of Odonatology, 12(2), 309-411. https://doi.org/10.1080/13887890.2009.9748347

Tews, J., Brose, U., Grimm, V., Tielborger, K., Wichmann, M. C., Schwager, M., \& Jeltsch, F. (2004). Animal species diversity driven by habitat heterogeneity/diversity: the importance of keystone structures. Journal of Biogeography, 31(3), 79-92. https://doi.org/10.5700/rege502

The Nature Conservancy (TNS), Fundación Vida Silvestre Argentina (FVSA), Fundación para el Desarrollo Sustentable del Chaco (DeSdel Chaco), \& Wildlife Conservation Society Bolivia (WCS). (2005). Evaluación ecoregional del Gran Chaco Americano/ Gran Chaco Americano ecoregional assessment (1st ed.). Buenos Aires, Argentina: Fundación Vida Silvestre Argentina.

Troast, D., Suhling, F., Jinguji, H., Sahlén, G., \& Ware, J. (2016). A global population genetic study of Pantala flavescens. PLoS ONE, 11(3), 1-13. https://doi.org/10.1371/journal.pone.0148949

Valente-Neto, F., De Oliveira Roque, F., Rodrigues, M. E., Juen, L., \& Swan, C. M. (2016). Toward a practical use of Neotropical odonates as bioindicators: Testing congruence across taxonomic resolution and life stages. Ecological Indicators, 61, 952-959. https://doi.org/10.1016/j.ecolind.2015.10.052 
Von Ellenrieder, N. (2000). Species composition and temporal variation of odonate assemblages in the subtropicalpampasic ecotone, Buenos Aires, Argentina. Odonatologica, 29(1), 17-30.

Von Ellenrieder, N. (2001). Species composition and distribution patterns of the Argentinian Aeshnidae (Odonata: Anisoptera). Revista de la Sociedad Entomológica Argentina, 60(1-4), 39-60.

Von Ellenrieder, N. (2008). Revalidation of Argentagrion and redefinition of Homeoura, with the description of $H$. obrieni n. sp. (Odonata: Coenagrionidae). Revista de La Sociedad Entomológica Argentina, 67(1-2), 81-106.

Von Ellenrieder, N. (2009a). Databasing dragonflies: State of knowledge in the Neotropical region. Agrion, 13(2), 58-72.

Von Ellenrieder, N. (2009b). Five new species of Orthemis from South America (Odonata: Libellulidae). International Journal of Odonatology, 12(2), 347-381. https://doi.org/10.1080/13887890.2009.9748351

Von Ellenrieder, N. (2010). Odonata biodiversity of the Argentine Chaco biome. International Journal of Odonatology, 13(1), 1-25. https://doi.org/10.1080/13887890.2010.9748357

Von Ellenrieder, N. (2012). The levis group of Orthemis revisited: A synopsis including a synonymy and description of six new species of Orthemis from South America (Odonata: Libellulidae). International Journal of Odonatology, 15(3), 115-207. https://doi.org/10.1080/13887890.2012.688186

Von Ellenrieder, N. (2014). A synopsis of the Neotropical genus Nephepeltia (Odonata: Libellulidae), including description of a new species, synonymies, and a key to males. Zootaxa, 3796(1), 121-146. https://doi.org/10.11646/zootaxa.3796.1.6

Von Ellenrieder, N, \& Garrison, R. W. (2007). Dragonflies of the Yungas (Odonata): a field guide to the species from Argentina. Pensoft publishers.

Von Ellenrieder, N, \& Garrison, R. W. (2008). The genus Oligoclada in Argentina, with description of O. rubribasalis sp. nov. (Odonata: Libellulidae). International Journal of Odonatology, 11(2), $249-260$. https://doi.org/10.1080/13887890.2008.9748327

Von Ellenrieder, N, \& Muzón, J. (1999). The Argentinean species of the genus Perithemis Hagen (Anisoptera: Libellulidae). Odonatologica, 28(4), 385-398.

Von Ellenrieder, N, \& Muzón, J. (2008). An updated checklist of the Odonata from Argentina. Odonatologica, 37(1), $55-68$.

Williamson, E. B. (1923). Notes on the Genus Erythemis with description of a new species (Odonata). Miscellaneous Publications Museum of Zoology, University of Michigan, (11).

Wolf, J. H. D. (1993). Diversity patterns and biomass of epiphytic bryophytes and lichens along an altitudinal gradient in the northern Andes. Annals of the Missouri Botanical Garden, 80, 928-960. 